\title{
Non-coeliac gluten sensitivity and coeliac disease
}

\author{
Dietary and diagnostic aspects
}

Gry Irene Skodje

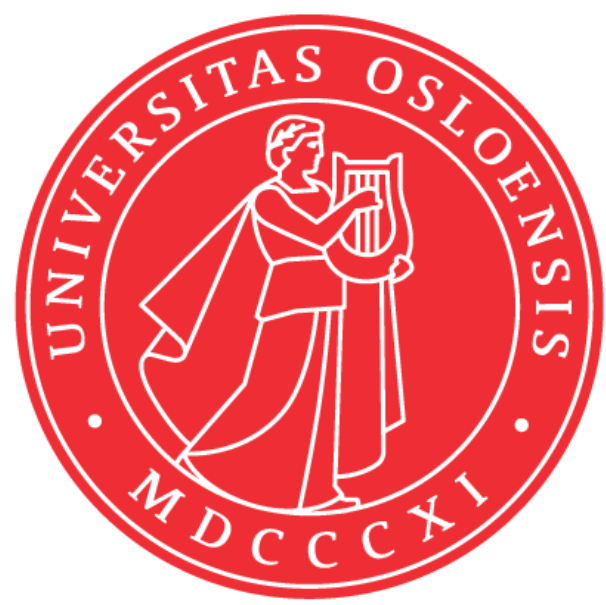

PhD Thesis

Institute of Clinical Medicine

Faculty of Medicine

UNIVERSITY OF OSLO 


\section{(C) Gry Irene Skodje, 2018}

Series of dissertations submitted to the Faculty of Medicine, University of Oslo

ISBN 978-82-8377-266-1

All rights reserved. No part of this publication may be reproduced or transmitted, in any form or by any means, without permission.

Cover: Hanne Baadsgaard Utigard.

Print production: Reprosentralen, University of Oslo. 


\section{SUMMARY}

Non-coeliac gluten sensitivity (NCGS) is a term within gluten-related disorders applied for the condition described by symptom relief on gluten-free diet in absence of coeliac disease and wheat allergy. An important characteristic is the experience of gastrointestinal and extra intestinal symptoms after intake of gluten containing food. There are no reliable diagnostic biomarkers. Expert consensus meetings have legitimized NCGS and proposed standardised, blinded, placebo-controlled gluten challenge with defined cut-offs for symptom change as a diagnostic tool. Yet the topic remains highly controversial. The role of gluten is particularly debated since gluten challenge studies have shown conflicting results. Our aim was first to study the adherence to gluten-free diet in coeliac disease and non-coeliac subjects, secondly, to evaluate diagnostic methods in both conditions, and finally, to investigate the separate effect of gluten and fructan in subjects with self-reported NCGS.

We found that gluten-free diet adherence did not differ between coeliac disease and NCGS subjects. Diet adherence was fair to good in NCGS even though most of them were self-educated in gluten-free diet. In open wheat challenges in subjects with presumed NCGS where a gastroenterologist evaluated symptom change without predefined cut-offs, $85 \%$ of the subjects had the suspicion of NCGS confirmed clinically. Interestingly, two proposed scoring systems for the evaluation of NCGS gave lower percentage of diagnosis compared to the gastroenterologist's evaluation. A 14-day gluten challenge of coeliac disease subjects showed the biological effects of a gluten containing muesli bar developed for challenge of NCGS subjects. The challenge was inadequate as diagnostic procedure for coeliac disease when villous blunting or increased coeliac disease specific antibody levels were used as outcome measures. Finally, we performed a randomised, double-blinded, placebo-controlled crossover challenge and found that fructan induced more gastrointestinal symptoms than gluten and placebo. Only four of 59 individuals had a symptomatic response compatible with NCGS, 24 had a pattern compatible with fructan inducible symptoms, whereas 22 in fact had their highest response to the placebo bar.

In conclusion, subjects with coeliac disease and self-reported NCGS adhered similarly to the glutenfree diet. Open wheat challenge with clinician-evaluation of symptom change in subjects with presumed NCGS overestimated the diagnosis as compared to suggested criteria. Also, gluten challenge of 14 days in subjects with coeliac disease in remission was too short to induce diagnostic changes, but proved the efficacy of the gluten. Finally, fructan emerged as the culprit that induced most gastrointestinal symptoms in subjects with self-reported NCGS. Our results illustrate the inadequacy of double-blinded, placebo-controlled food challenge as a diagnostic tool. They further question the entity NCGS and suggest that the condition should be regarded as a variant of irritable bowel syndrome. 


\section{Acknowledgments}

This thesis is based upon studies conducted at Oslo University Hospital in collaboration with Institute for Clinical Medicine, Department of Nutrition Research, Institute of Immunology and K.G. Jebsen Centre for Coeliac Disease Research, all at the University of Oslo. We also collaborated with the research group of Jane Muir and Peter Gibson at Monash University, Melbourne. The work was funded by the Norwegian Extra Foundation for Health and Rehabilitation and supported by Norwegian Coeliac Association, Throne Holst Foundation, Wedel Jarlsberg Foundation and Freia Foundation for Research.

Thanks to all the study participants, whose contribution made this research possible.

Sincere gratitude goes to my supervisor, Knut Lundin for inviting me into the research world. You are a well of inspiration, encouragement, trust, empathy, support, good stories and never-ending optimism. It has been a delight to work with you! I was blessed with Christine Henriksen and Marit Veierød as co-supervisors. Christine, you were heavenly sent when you boldly invited yourself and made the team complete. Your confidence, creativity and deep consideration have been a great motivation. Marit, you are the queen of details and correctness. I love that! Thanks for all statistical guidance. To all three, I am profoundly grateful for your high quality and versatile supervision. I have been a fortunate student.

A special thanks to Vikas Sarna, I was lucky to have you as fellow PhD student. Thanks for discussions and great collaboration. We made a great team.

Thanks to my hardworking and dedicated master students, Kjersti Langballe Rolfsen and Ingunn Hillestad Minelle. Anne Beate Hvinden, thank you for invaluable practical assistance. Great thanks for laboratory assistance from the always present Jorunn Bratli, Merete Gedde-Dahl and Carina Hinrich. Thanks to the Nutrition outpatient clinic at OUS for human and technical resources in a period of crisis. Martha Colban gave thorough, practical scientific advice and assistance for randomization and blinding. Thank you!

To my family and friends: Thank you for being there, with patience, trust, interest and endless support. Thanks to Tommy, and most importantly, Ada \& Sverre, thank you for being what truly matters in life.

Gry Irene Skodje

Oslo, February 2018 


\section{TABLE OF CONTENTS}

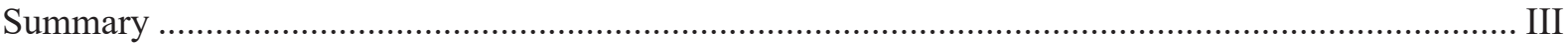

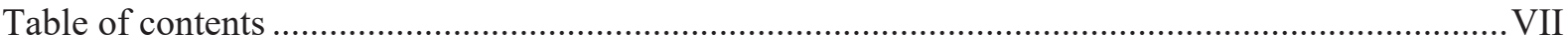

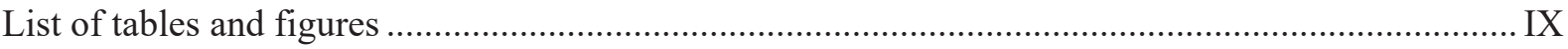

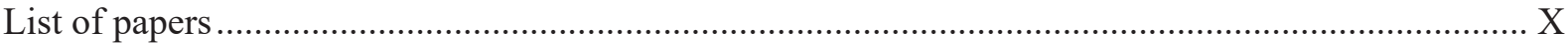

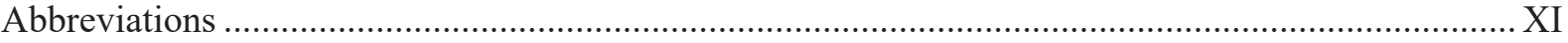

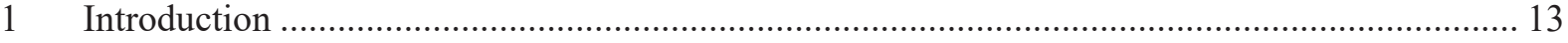

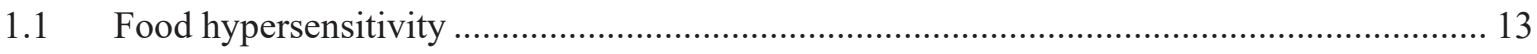

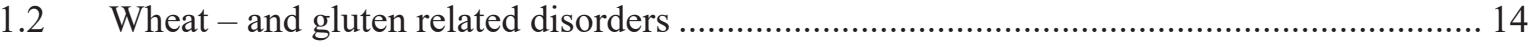

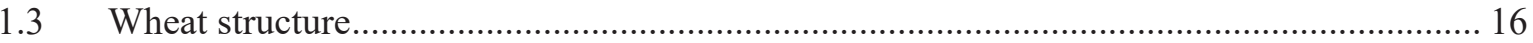

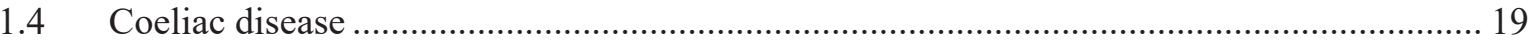

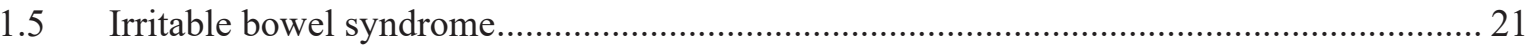

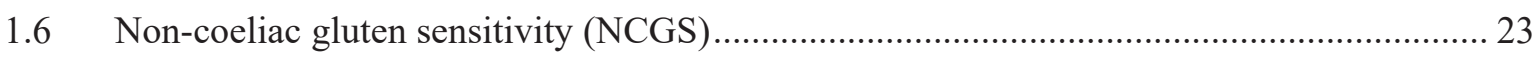

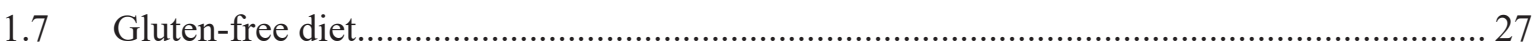

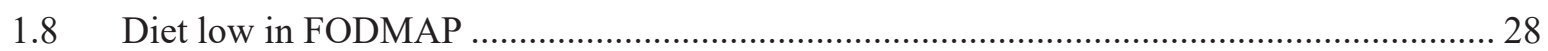

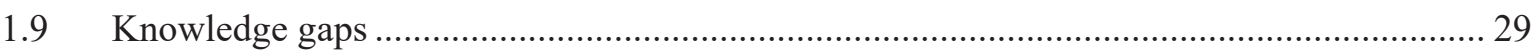

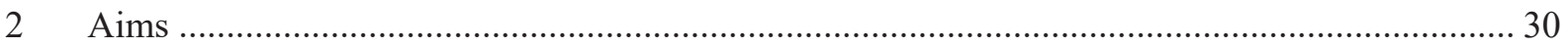

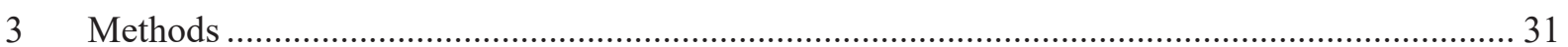

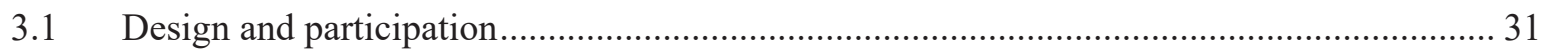

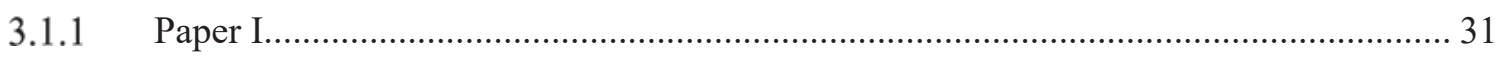

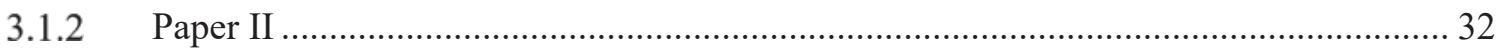

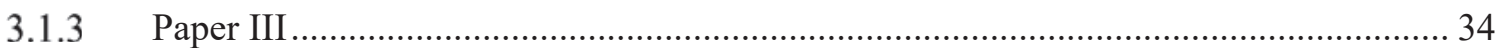

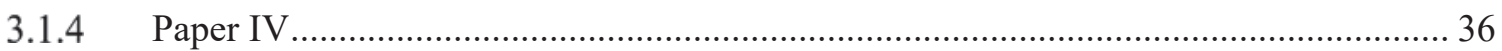

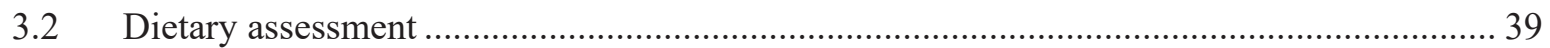

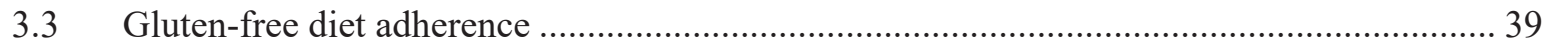

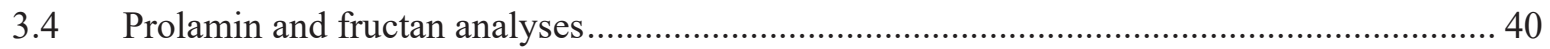

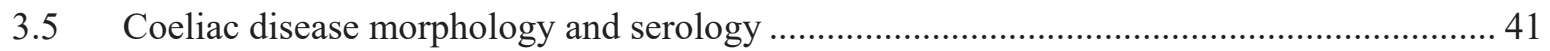

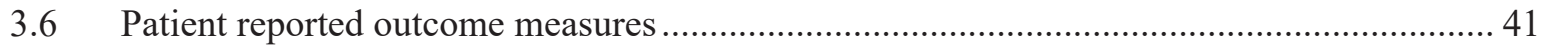

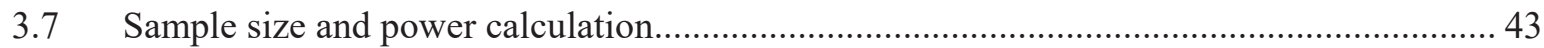

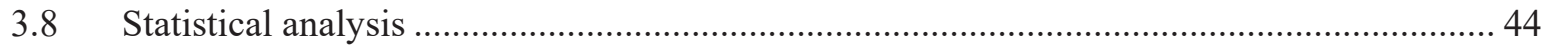

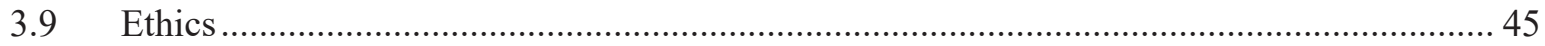

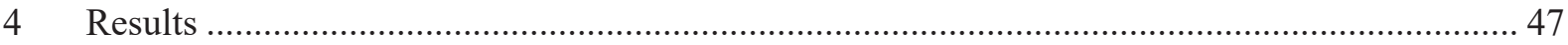

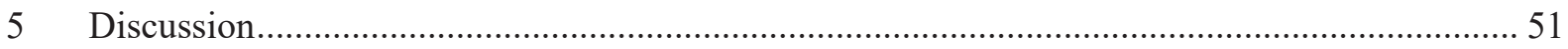

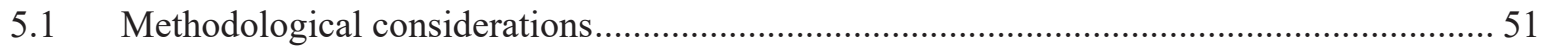

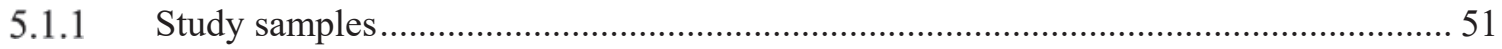




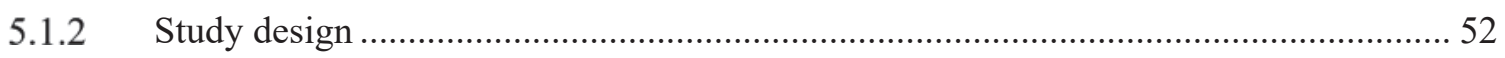

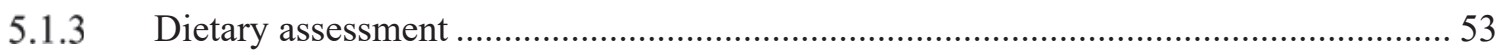

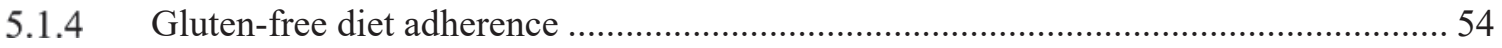

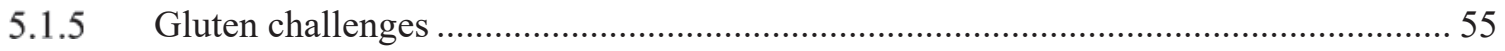

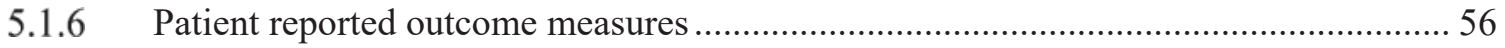

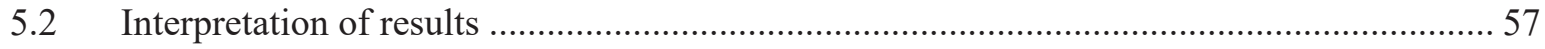

5.2.1 Diet adherence in coeliac and non-coeliac patients ................................................... 57

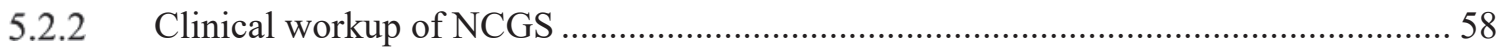

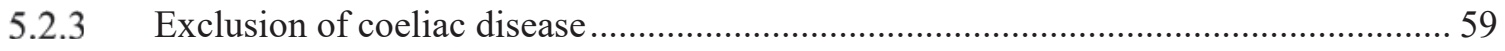

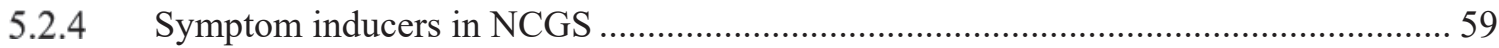

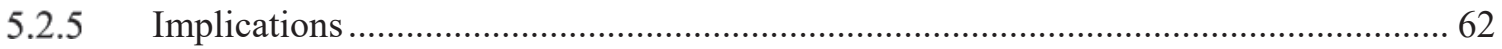

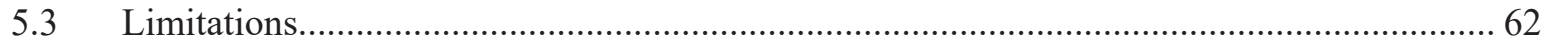

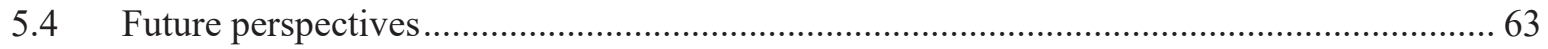

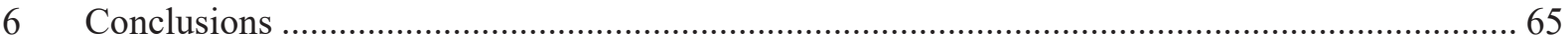

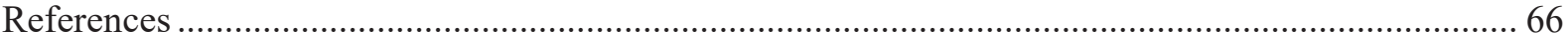




\section{LIST OF TABLES AND FIGURES}

Table 1 Disorders with confirmed and suggested relation to wheat and gluten................................... 15

Table 2 Rome III Criteria for irritable bowel syndrome ..................................................................... 22

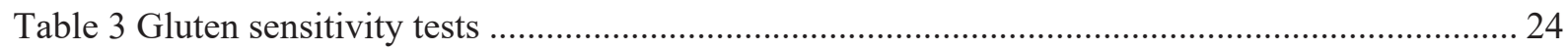

Table 4 Observations of biochemical and physiological features in NCGS and IBS .......................... 25

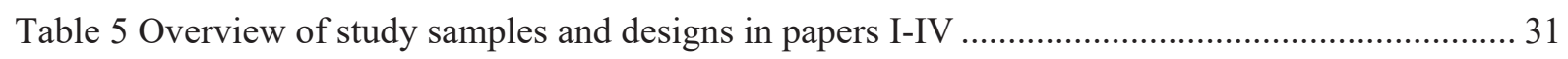

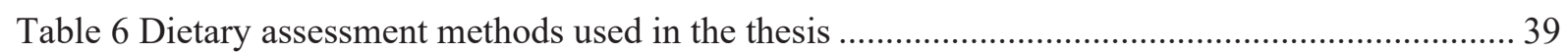

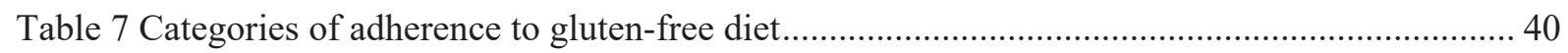

Table 8 Overview of patient reported outcome measures used in the thesis...................................... 42

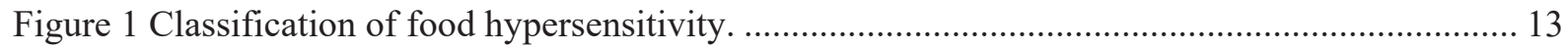

Figure 2 Food elimination and reintroduction in food hypersensitivity ............................................ 14

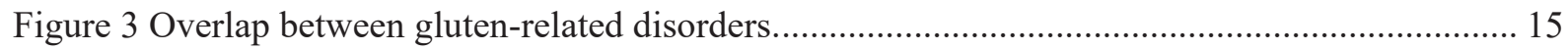

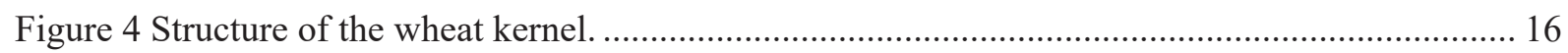

Figure 5 Sub-groups of fermentable oligo-, di-, monosaccharides and polyols (FODMAP)................ 18

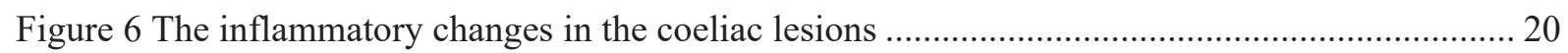

Figure 7 Suggested algorithm for the workup of non-coeliac gluten sensitivity (NCGS) ................... 26

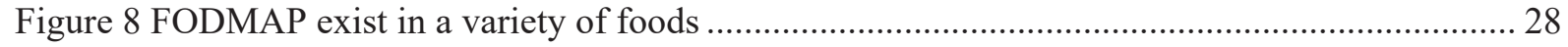

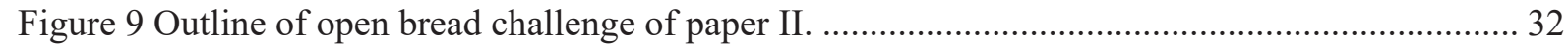

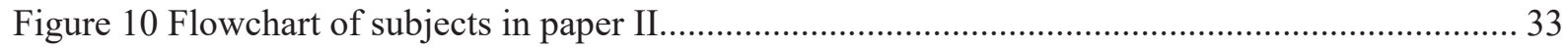

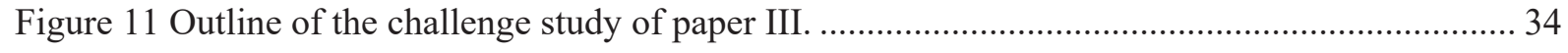

Figure 12 Quinoa-based muesli bar as challenge vehicle in the study of paper III and IV.................. 34

Figure 13 Flowchart of subjects in paper III. .............................................................................. 35

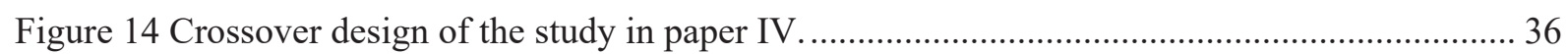

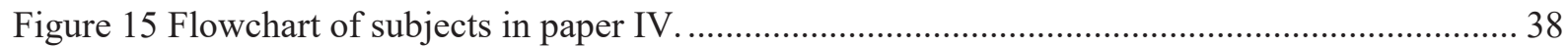




\section{LIST OF PAPERS}

\section{Paper I}

Diet adherence and gluten exposure in coeliac disease and self-reported non-coeliac gluten sensitivity.

Løvik A, Skodje G, Bratlie, J, Brottveit B, Lundin KEA

Clin. Nutr., 2017 Feb:36(1):275-280. Published online: December 10, 2015. PMID: 26714791

\section{Paper II}

Wheat challenge in self-reported gluten sensitivity: a comparison of scoring methods.

Skodje GI, Henriksen C, Salte T, Drivenes T, Toleikyte I, Løvik AM, Veierød MB, Lundin KEA

Scand. J Gatroenterol. 2017 Feb:52(2):185-192. Published online: October 31, 2016. PMID: 27797273

\section{Paper III}

HLA-DQ:gluten tetramer test in blood gives better detection of coeliac patients than biopsy after 14day gluten challenge.

Sarna VK, Skodje GI, Reims HM, Risnes LF, Dahal-Koirala S, Sollid LM, Lundin KEA.

Gut. 2017 Aug 4. PMID: 28779027

\section{Paper IV}

Fructan, rather than gluten, induces symptoms in patients with self-reported non-celiac gluten sensitivity

Skodje GI, Sarna VK, Minelle IH, Rolfsen KL, Muir JG, Gibson PR, Veierød MB, Henriksen C, Lundin KEA.

Gastroenterology 2018 Feb:154(3):529-539. Published online: November 2, 2017. PMID: 29102613 


\section{ABBREVIATIONS}

ATI Amylase trypsin inhibitor

BMR Basal metabolic rate

CDAT Coeliac disease adherence test

CI Confidence interval

CSI Coeliac symptom index

DBPCFC Double-blind placebo-controlled food challenge

DGP Deamidated gliadin-peptide

FODMAP Fermentable oligo-, di-, monosaccharides and polyols

GBB Giessen subjective complaint list

GSRS Gastrointestinal symptom rating scale

HAD Hospital anxiety and depression scale

HLA Human leukocyte antigen

HRQoL Health related quality of life

IBS Irritable bowel syndrome

IEL Intraepithelial lymphocytes

Ig Immune globulin

IQR Interquartile range

m-RNA Messenger ribonucleic acid

NCGS Non-coeliac gluten sensitivity

RCT Randomised clinical trial

SD Standard deviation

SF-36 Short Form-36

TG2 Tissue transglutaminase 2

VAS Visual analogue scale

Vh/Cd Villous height to crypt depth ratio

WA Wheat allergy 


\section{INTRODUCTION}

\subsection{Food hypersensitivity}

Food hypersensitivity is a frequently reported condition in the western world. It causes people to exclude single or several foods from the diet in order to obtain symptom relief or better health. An emerging trend has been people on elimination diets without necessarily well-founded medical indications, such as the milk-free diet and the wheat- or gluten-free diet. In western countries 15-20\% of the population perceives some form of food intolerance ${ }^{1}$. Approximately $20 \%$ of the population alters the diet on the suspicion of an adverse reaction to food or a food component, although the prevalence of food allergy based on oral food challenge is only 1-2 $\%^{2-5}$. In people with functional gastrointestinal disorders, such as irritable bowel syndrome (IBS), 50-84 \% perceives their symptoms are related to food intake ${ }^{6-8}$. Diet restrictions may have impact on nutritional status and cause malnutrition or deficiency of certain nutrients if not managed or supplemented adequately. Deviant diets may also affect quality of life and private economy.

Food hypersensitivity is generally either immunological such as food allergy, or non-immunological without activation of the immune system, often termed food intolerance (Figure 1) ${ }^{9,10}$. Wheat allergy and coeliac disease are examples of immunological conditions and lactose intolerance is a nonimmunological food hypersensitivity. Food allergies are most often diagnosed easily by blood tests ${ }^{11}$. In contrast, food intolerances, mostly lack objective biomarkers in the clinical workup.

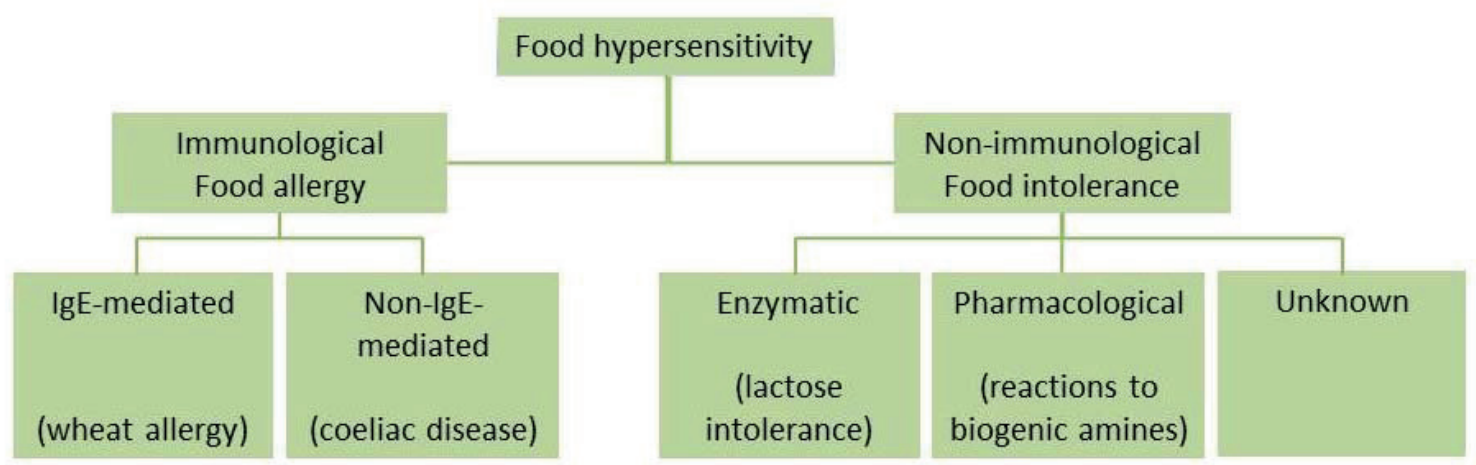

Figure 1 Classification of food hypersensitivity.

The medical investigation of suspected food intolerances ideally takes place in a multidisciplinary context where exclusion of other potential disease is crucial. Further, the workup includes a thorough medical history with dietary and lifestyle assessment focused on potential diet-related symptoms, 
preferably by an experienced dietitian. The standard food intolerance test is food exclusion followed by systematic reintroduction and subsequent symptom induction to identify tolerance threshold (Figure 2) ${ }^{12-14}$. Reintroduction or challenge can be done either open or blinded depending on the nature of the symptoms. The gold standard diagnostic method is the double-blind placebo-controlled food challenge (DBPCFC). Objective acute onset symptoms like skin rash is more suitable for open challenge than subjective late onset symptoms ${ }^{15}$. In contrast to food allergy the food exclusion in food intolerance is based on reduction rather than complete exclusion. The method is often not straightforward and avoiding several dietary components may be required. When a restricted diet is indicated for long-term management, it should be supervised by a dietitian to avoid unnecessary restrictions and reduce the risk of nutritional deficiencies ${ }^{16}$.

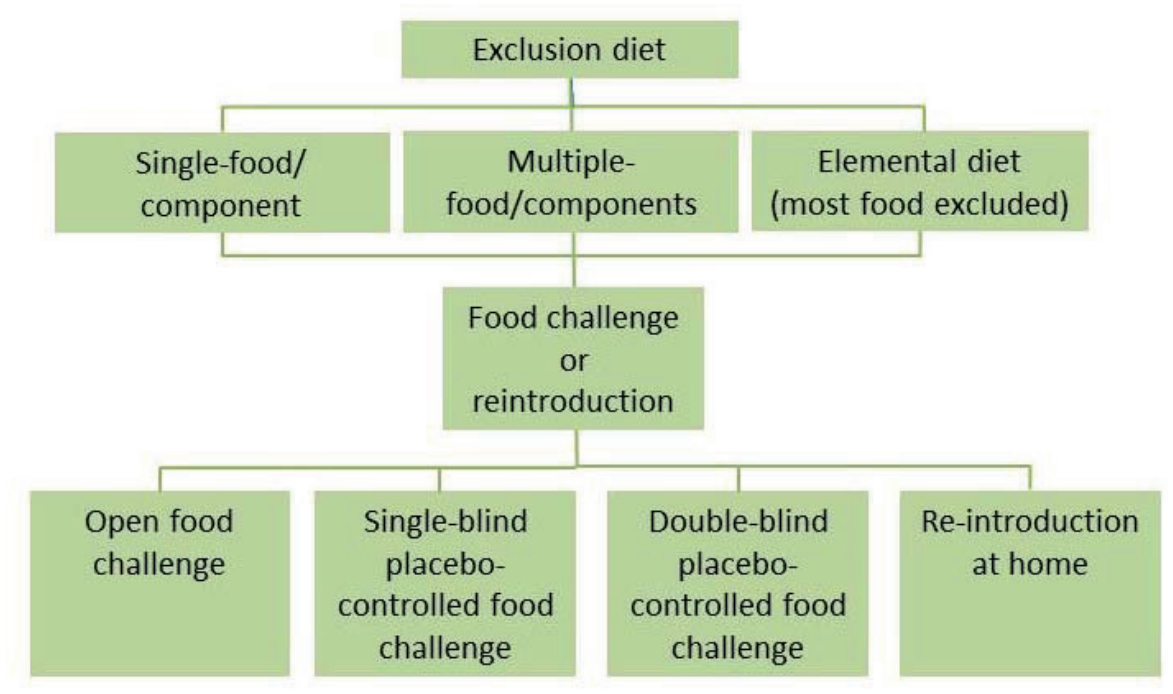

Figure 2 Food elimination and reintroduction in food hypersensitivity

\subsection{Wheat - and gluten related disorders}

Gluten and wheat are the main drivers of coeliac disease and wheat allergy. Unlike food intolerances, these two conditions have well-defined epidemiology, pathogenic mechanisms, diagnostic markers and treatment (Table 1) ${ }^{17,18}$. Wheat allergy is defined by an immune globuline (Ig) E-mediated immune reaction in response to wheat ingestion and requires complete elimination of wheat from the diet. Wheat can also precipitate as a trigger of wheat-dependent exercise-induced anaphylaxis ${ }^{19}$. Those who are affected are asymptomatic except when wheat is consumed in close proximity to exercise. Coeliac disease is caused by an abnormal immune response to gluten proteins in wheat, rye and barley and requires a strict and lifelong gluten-free diet ${ }^{20,21}$. IBS is a functional gastrointestinal disorder in which symptoms may improve in response to dietary restrictions which may include wheat or gluten ${ }^{7}$. Here, the pathogenic mechanism is more obscure. Later sections will describe coeliac 
disease and IBS in depth. The last decade there has been a worldwide increase of people with selfdiagnosed gluten sensitivity with clinical manifestations similar to coeliac disease but without the enteropathy or serologic features of coeliac disease, and without wheat allergy. They report improvement of gastrointestinal and extra-intestinal health in response to a self-instituted gluten-free diet. A definition paper of 2012 suggested including "non-coeliac gluten sensitivity" (NCGS) in the term of gluten-related disorders ${ }^{22}$. Although the gluten-specificity has not been proven, the term has been used since. The true prevalence is unknown and estimates from some prevalence studies range from $0.6 \%$ to $10.6 \%{ }^{23,24}$.

Table 1 Disorders with confirmed and suggested relation to wheat and gluten

\begin{tabular}{lcccc}
\hline Disease & Prevalence $(\%)$ & Biomarker & Diagnostics & Management \\
\hline Wheat allergy & 0.1 & IgE antibody & IgE + DBPCFC & Wheat-free diet \\
Coeliac disease & 1 & TG2-IgA & Duodenal biopsy & Gluten-free diet \\
\hline IBS & $10-20$ & - & Clinical assessment & Lifestyle, diet, medication \\
NCGS & $0.6-10$ & - & - & Gluten-free diet \\
\hline
\end{tabular}

DBPCFC; double-blind placebo-controlled food challenge, IBS; irritable bowel syndrome, Ig; immunoglobulin, NCGS; non-coeliac gluten sensitivity, TG2; transglutaminase 2

\section{Overlapping diagnosis}

Approximately 20-30 \% of treated coeliac disease patients present with IBS symptoms, and the two conditions coexist in some patients ${ }^{25-27}$. Guidelines therefore recommend excluding coeliac disease in all patients referred with IBS ${ }^{28-31}$. Figure 3 demonstrates the overlap between coeliac disease, IBS, NCGS and wheat allergy and presents the two main views about NCGS as an independent entity (Figure $3 \mathrm{~A}$ ) ${ }^{32-35}$ or a condition that belongs to IBS (Figure $3 \mathrm{~B}$ ) ${ }^{36-39}$.
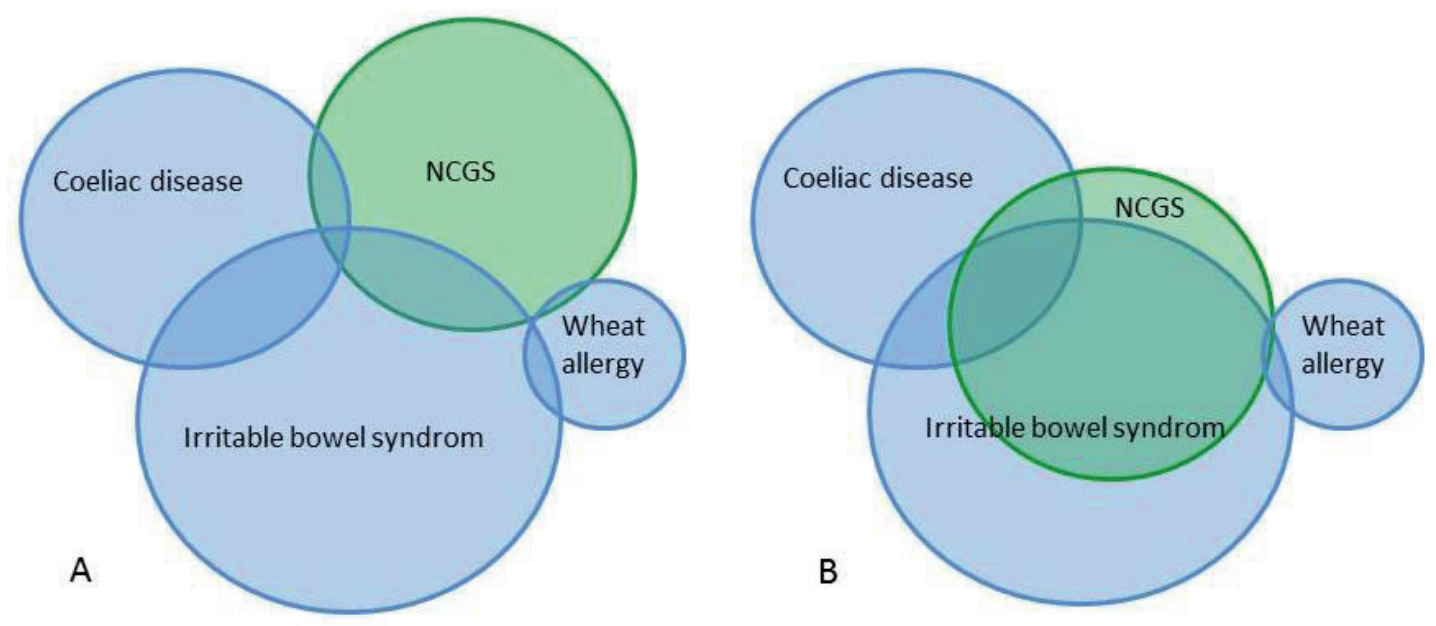

Figure 3 Overlap between gluten-related disorders. Adapted with permission from Husby et al.2015 ${ }^{32}$. NCGS, non-coeliac gluten-sensitivity. 


\subsection{Wheat structure}

Wheat is among the most important food plants used for human alimentation and one of the world's major food crops, cultivated, consumed, and traded in all continents. The earliest forms of wheat were diploid einkorn (Triticum monococcum) and tetraploid emmer (Triticum turgidum). Evolution with hybridization between cultivated emmer and wild grasses has led to the currently most widely cultivated tetraploid (Triticum durum) and hexaploid (Triticum aestivum) wheat variants ${ }^{40}$. About $95 \%$ of the wheat grown worldwide is the hexaploid variant because of the ability to adapt to different meteorological conditions ${ }^{40}$. The wheat kernel contains a fibre part called bran (14\%), the embryo or germ ( $3 \%)$ and the endosperm ( $80 \%$ ) (Figure 4$)$. Although the quantity and quality of starch and lipids in wheat caryopsis contribute to the derived flour characteristics, proteins are the most important components that determine the features of flours. The principal wheat proteins are albumin, globulin, glutenin and gliadin. About $85 \%$ of the caryopsis consists of carbohydrates, of which most of it is starch and a smaller part is mono-, di- and oligosaccharides, including fructans (fructooligosaccharides) ${ }^{40}$.

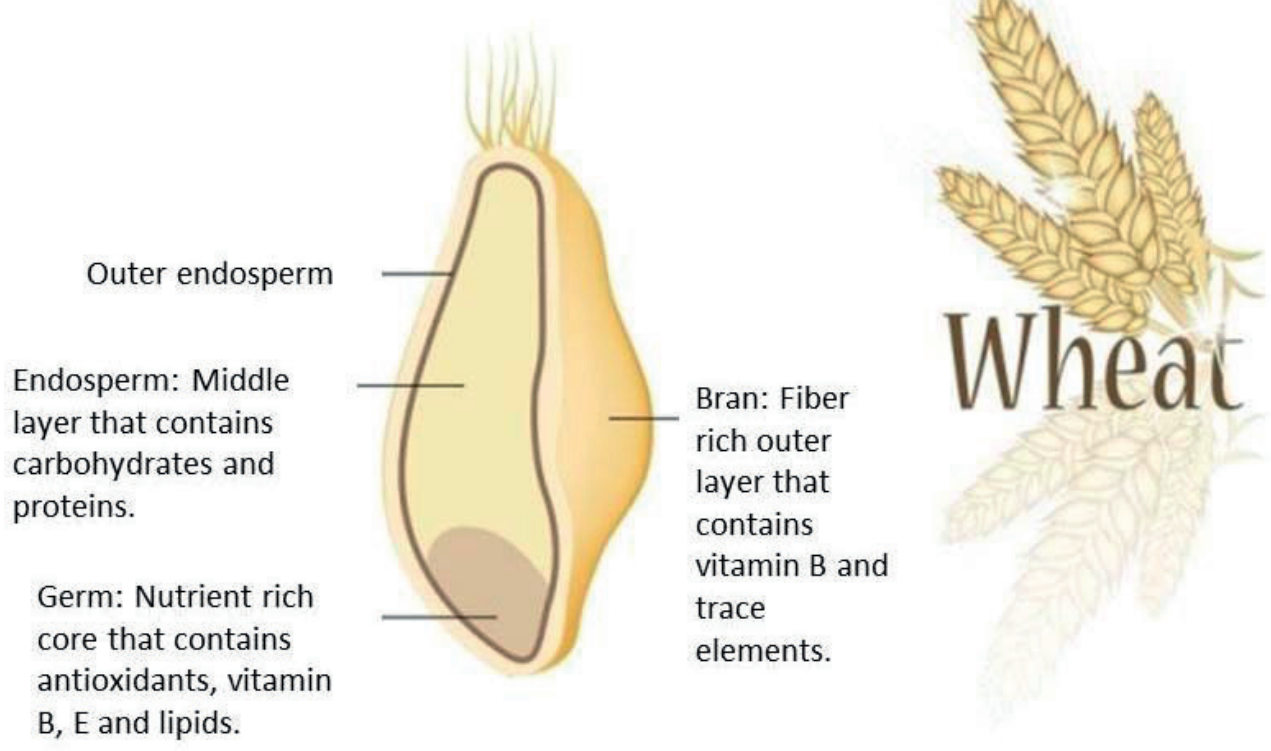

Figure 4 Structure of the wheat kernel (picture from www.photosearch.no). 


\section{Gluten}

Gluten is a complex mixture of proteins, mainly gliadin and glutenin, which are referred to as prolamins ${ }^{41}$. Prolamins represent $80-90 \%$ of the wheat kernel proteins. Similar storage proteins exist as secalin in rye, hordein in barley, and avenins in oats and are collectively referred to as "gluten" 41,42. Gluten is heat stable and is of fundamental importance for the overall appearance and textural properties of wheat-based baked products ${ }^{40}$. Calculations of dietary gluten intake are approximate as they are normally estimated by the amount of protein in gluten-containing cereals. The average daily gluten intake in a Western diet is thought to range from 5 to $20 \mathrm{~g}$ per day. In 1997 a Dutch study found a mean gluten intake in adults of $13.1 \mathrm{~g}$ per day ${ }^{41}$. Recent Danish population-based data of adults aged 20-75 years showed a mean (SD) gluten intake of $10.4 \mathrm{~g}$ per day (4.4) ${ }^{43}$. There is some evidence that modern baking practices with shortened leaving and the use of vital gluten (carbohydrate depleted wheat flour) as a food additive has resulted in increased exposure to gluten ${ }^{40}$.

\section{Amylase-trypsin inhibitors}

Other wheat proteins include proteins associated with cell structures and enzymes. Amylase-trypsin inhibitors (ATIs) are albumin proteins acting as a natural defence of the plant and accounts for 2-4 \% of the total protein in wheat. They may be involved in IgE-mediated mechanisms of wheat allergy ${ }^{44}$. Some of the ATIs have been reported to activate a toll-like receptor-4 dependent pathway leading to the release of pro-inflammatory cytokines in cell lines derived from coeliac and non-coeliac patients ${ }^{45}$, 46.

\section{Wheat germ agglutinin}

Wheat germ agglutinin is a lectin, a carbohydrate binding protein found in the wheat kernel. In vitro, wheat germ agglutinin has shown epithelial damaging and immune effects. It may therefore contribute to intestinal manifestations associated with gluten intake ${ }^{47}$.

\section{Fructans}

Fructans are subtypes of the FODMAP, the acronym for fermentable oligo-, di-, monosaccharides and polyols which are found in a variety of foods (Figure 5$)^{48}$. Oligosaccharide fructans are polymers of fructose molecules that occur as storage carbohydrates in various plants, particularly in cereals such as wheat, rye, barley, oats and in onions, leeks, asparagus, lettuce and sunflowers ${ }^{49}$. These polymers are fructose residues linked to a terminal sucrose residue by glycosidic bonds, and fructans of shorter length are known as fructooligosaccharides ${ }^{50}$. The small intestine is not able to absorb fructans, so they continue to the colon and become fermented by the colonic bacteria ${ }^{51,52}$. Since wheat is the most 
important dietary source, fructans have received special interest because of the coexistence with gluten and the known capability of inducing gut symptoms ${ }^{53-56}$.

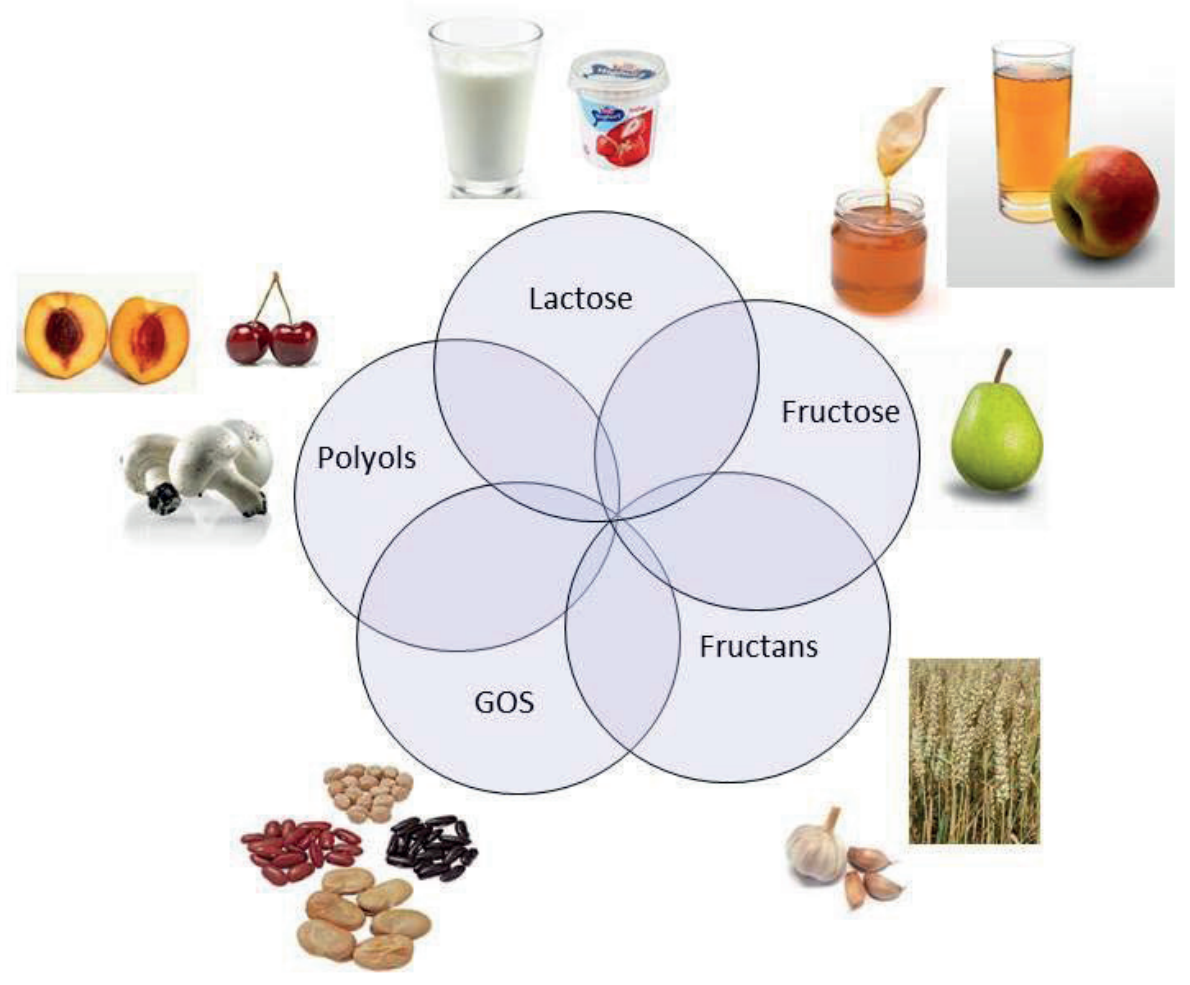

Figure 5 Sub-groups of fermentable oligo-, di-, monosaccharides and polyols (FODMAP) and examples of food sources. Overlapping circles indicate that a single food item often contains several types of FODMAP. GOS; galactooligosaccharides (adapted from Tuck CJ and Gibson PR, International Coeliac Disease Symposium, Prague, Czech Republic 2015). 


\subsection{Coeliac disease}

\section{Definition}

In the classifications of food hypersensitivities, coeliac disease belongs to the conditions characterized with immunological reactions (Figure 1). Coeliac disease is an intestinal inflammatory disease defined as chronic small intestinal immune-mediated enteropathy precipitated by exposure to dietary gluten in individuals genetically predisposed with the human leukocyte antigen (HLA)-DQ2 and/or DQ8 genotype $^{22}$. The gluten protein was identified as the culprit of coeliac disease by the Dutch physician, Dicke, who observed that coeliac children symptomatically improved when wheat and rye were scarce during the 1944-45 famine ${ }^{57,58}$.

\section{Epidemiology}

Coeliac disease is a lifelong disorder that can occur at all ages. It is an autoimmune condition that is twice more frequent in women than in men ${ }^{59}$. The overall prevalence in the Western population is approximately $1 \%$ and somewhat higher in certain European countries ${ }^{60}$. The prevalence of coeliac disease is higher in populations at risk as in type 1 diabetes (3-6\%), first-degree coeliac relatives (up to $20 \%$ ), symptomatic (10-15\%) and asymptomatic iron deficiency anaemia (3-6 \%) and osteoporosis $(1-3 \%)^{61}$.

\section{Pathophysiology}

Coeliac disease arises from the interplay of genetic, environmental and immunological factors, and the pathogenesis is better understood than any other HLA-associated diseases ${ }^{62}$. Much of this research has been pioneered in Oslo at the Institute of Immunology, University of Oslo ${ }^{63}$. The disease is caused by an inappropriate immune response to dietary gluten proteins (Figure 6). Gliadin contains peptide sequences that are highly resistant to gastric, pancreatic and intestinal proteolytic digestion in the gastrointestinal tract. The reason gliadin escapes degradation is the content of the amino acids proline and glutamine, which many proteases are unable to cleave ${ }^{64}$. These proline-rich residues are responsible for mediating the adverse immune response ${ }^{20}$. This immune response is controlled by $\mathrm{CD}^{+} \mathrm{T}$ cells in the lamina propria that recognize gluten peptides in the context of HLA-DQ2 or DQ8 molecules ${ }^{20,65-67}$. The $\mathrm{T}$ cells are specific for proline and glutamine rich peptides in gluten that resist proteolysis. The glutamine residues become deamidated by the enzyme transglutaminase 2 (TG2). These immunological reactions result in inflammatory changes including increased intraepithelial lymphocytes (IEL), decreased enterocyte height, villous atrophy and crypt hyperplasia ${ }^{20}$. Whereas much of the pathogenesis of the disease now is understood, the triggering event(s) initiating the immunopathology is not well defined. Viruses that infect the intestines may certainly be prime candidates ${ }^{68-70}$. 


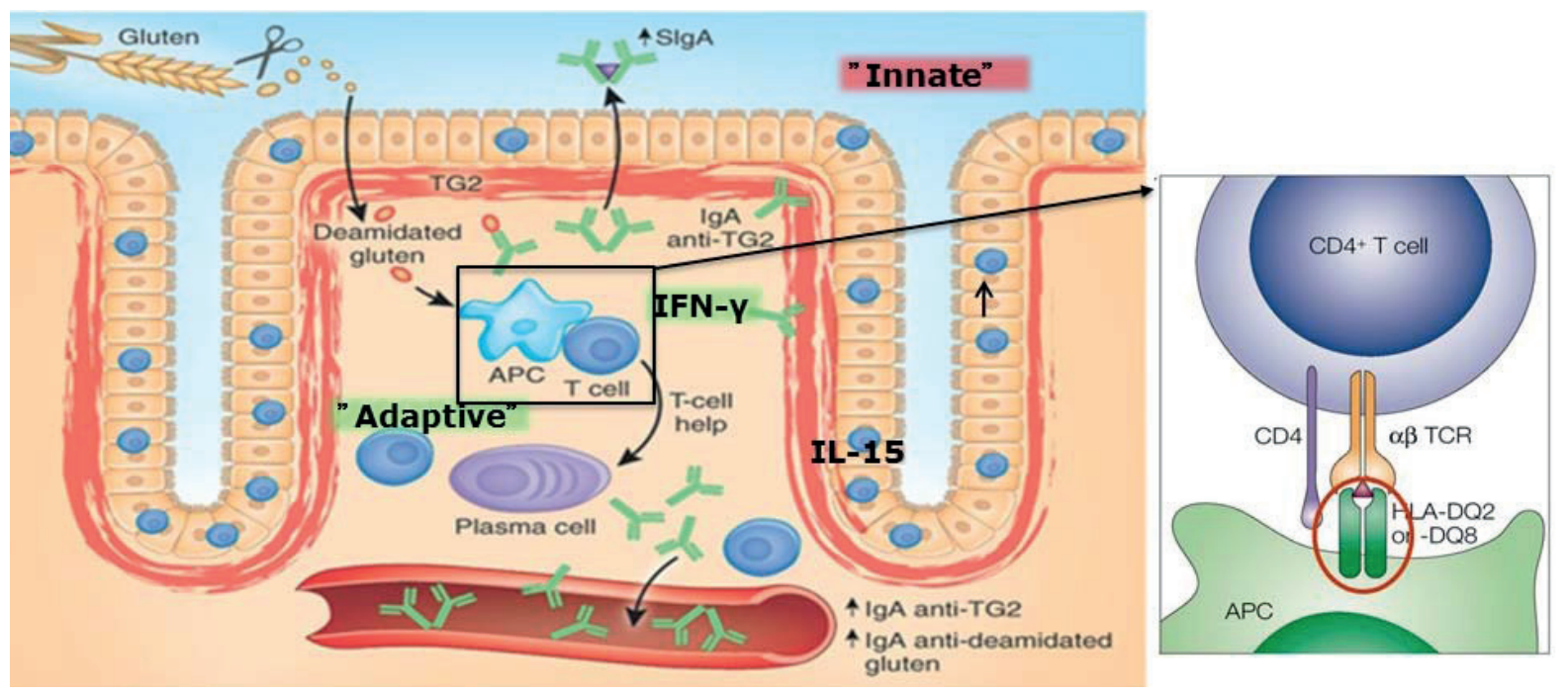

Figure 6 The inflammatory changes in the coeliac lesions (adapted with permission from Sollid \& Lundin 2009) ${ }^{20}$.

\section{Diagnostics}

The coeliac disease diagnosis depends on a combination of clinical signs, serological analysis and small intestinal morphology findings ${ }^{60}$. Coeliac disease can present with gastrointestinal symptoms such as diarrhoea, steatorrhea, bloating and abdominal pain, but also extra intestinal abnormalities such as abnormal liver tests, bone disease, iron deficiency and skin disorders ${ }^{18}$. Serology usually includes measurements of IgA antibodies to tissue transglutaminase and/or IgG antibodies to deamidated gliadin peptides. Tissue transglutaminase has $95 \%$ specificity and is often seen with elevated endomysial and deamidated antigliadin antibodies, which are also sensitive biomarkers for detection of coeliac disease, but not specific for the diagnosis ${ }^{60}$. The diagnosis is confirmed by increased intraepithelial lymphocyte count, hypertrophic crypts and partial or total deterioration of villi in duodenal biopsies performed while the patient is still on a gluten containing diet ${ }^{18}$. Popular awareness of potential gluten-related health problems has led to increasing number of individuals pursuing self-prescribed gluten-free diet, without an adequate diagnostic workup of coeliac disease ${ }^{71}$. This practice poses a diagnostic challenge to clinicians, as sensitivity of available tests for diagnosis of coeliac disease reduces significantly in subjects who are not eating gluten. In such cases, recent guidelines recommend challenge with $3 \mathrm{~g}$ gluten daily for at least two weeks, prolonged to eight weeks if possible, followed by duodenal biopsy ${ }^{18,60,72}$. The recommendation of at least 2-week gluten challenge is based on limited evidence, and the sensitivity of this procedure is not well validated ${ }^{72}$. Consumption of gluten may elicit strong symptoms and patients may be reluctant to eat glutencontaining food in order to provoke diagnostic intestinal changes. This may result in a too short period of gluten exposure in order to have a reliable duodenal biopsy ${ }^{73}$. 


\subsection{Irritable bowel syndrome}

\section{Definition}

IBS is a chronic functional gastrointestinal disorder in which recurrent abdominal pain is associated with defecation or a change in bowel habits ${ }^{74}$. IBS subtypes are classified according to the 7-point Bristol Stool Form Scale and include constipation predominant, diarrhoea predominant, and IBS with predominant irregular bowel habits with a mix of diarrhoea and constipation ${ }^{74,75}$.

\section{Epidemiology}

Throughout the world, about 10-20\% of adults and adolescents have symptoms consistent with IBS, and most studies find a predominance females ${ }^{76}$. IBS symptoms come and go over time, often overlap with other functional disorders and result in a significant psychosocial burden ${ }^{77}$. It has been estimated that IBS is responsible for about one-third of all referrals to gastroenterology specialists and is associated with significant economic costs ${ }^{78,79}$.

\section{Pathophysiology}

A number of pathophysiological abnormalities have been described in IBS and include visceral hypersensitivity ${ }^{80,81}$, motility changes ${ }^{82}$, infectious gastroenteritis ${ }^{83,84}$, intestinal inflammation (ref), altered microbiota ${ }^{85-87}$ and psychosocial factors ${ }^{88}$. However, IBS is also associated with food intolerances, and approximately $84 \%$ of patients report that symptoms are related to certain food items ${ }^{89,90}$. Studies have found that IBS patients may respond to elimination diets ${ }^{91,92}$. Exclusion dietrechallenge methodologies applied to patients with IBS have identified foods comprising large content of wheat and other grains as frequent culprits in inducing symptoms ${ }^{53,93,94}$. Abdominal symptoms have been specifically induced following challenges with oligosaccharides ${ }^{95-99}$. 


\section{Diagnostics}

In absence of objective biomarkers and alarm symptoms, an important part of the diagnosis of IBS is the exclusion of other possible diseases. Further, the Rome Foundation has developed clinical guidelines for the diagnostics of IBS, last updated to the Rome IV criteria in $2016^{74}$. The assessment includes history of symptoms regarding onset, duration and frequency. Symptoms and stool patterns are further described and bowel habits categorised by the Bristol Stool Form ${ }^{75}$. In this thesis subjects with IBS were defined by the Rome III criteria as shown in Table $2{ }^{100}$.

Table 2 Rome III Criteria for irritable bowel syndrome

\begin{tabular}{l|l}
\hline Characteristic & Rome III \\
\hline Diagnostic time frame & $\begin{array}{l}\text { Symptom onset at least six months prior } \\
\text { Symptom activity during the last three months } \\
\text { Symptom frequency the last three months }\end{array}$ \\
\hline Symptom description & Abdominal discomfort and pain \\
\hline Symptom association & $\begin{array}{l}\text { Improvement with defecation } \\
\text { Onset associated with change in the form of stool } \\
\text { Onset associated with the change in the frequency of stool }\end{array}$ \\
\hline $\begin{array}{l}\text { Predominant stool pattern of } \\
\text { IBS subtype }\end{array}$ & Stool type based on bowel movements on all days \\
\hline Tool to categorise bowel habit & Bristol Stool Form Scale \\
\hline
\end{tabular}

IBS; irritable bowel syndrome.

\section{Management}

Management of IBS include lifestyle and dietary modifications, psychological and behavioural treatments and different types of medication such as opioid agonists, antidepressants, antispasmodics, probiotics and antibiotics ${ }^{74,101-103}$. However, in recent years, the dietary approach has received increased attention, and many studies have found effect of dietary guidance on symptoms and quality of life in IBS patients ${ }^{104-106}$.

Approximately $80 \%$ of patients with IBS report food intolerances ${ }^{7}$ and studies have claimed that IBS patients may benefit from a gluten-free diet, in particular the diarrhoea predominant subtype ${ }^{107-110}$. The clinical and scientific community has been quick to point to gluten as the pathogenic molecule. Vazquez-Roque et al suggested that effect of gluten-free diet on symptoms and bowel barrier functions in IBS-D was attributed to the removal of gluten ${ }^{110}$, and Shahzbazkhani et al. claimed that many patients diagnosed with IBS were gluten sensitive and that their symptoms could be controlled with a gluten-free diet ${ }^{109}$. 


\subsection{Non-coeliac gluten sensitivity (NCGS)}

\section{Definition}

In 2012 Lundin and Alaedini suggested to define NCGS as a condition "associated with the experiencing of various symptoms in response to ingestion of foods containing wheat, rye and barley, and the resolution of symptoms on removal of those foods from diet in individuals in whom coeliac disease and wheat allergy have been ruled out" 22,111 .

The first descriptions of gluten sensitivity in absence of coeliac disease were done in England in 1976 ${ }^{112}$. The researchers performed a challenge study of eight women with dramatic relief of symptoms as response to gluten-free diet, and without evidence of coeliac disease. Further, they found significant worsening of abdominal pain and diarrhoea in response to four-week gluten exposure ${ }^{112}$. However, this gluten challenge is poorly described. The phenomenon has been "rediscovered" in recent years and described by Verdu et al. as the "no man's land" between IBS and coeliac disease ${ }^{113}$, and several review articles and editorials have been published ${ }^{33,38,114-118}$. Biesiekierski et al. demonstrated in a double-blind randomised placebo-controlled trial that gluten caused gastrointestinal symptoms in subjects without coeliac disease. The study was sited in support of the existence of NCGS ${ }^{107}$. However, a follow-up study was not able to reproduce the findings ${ }^{119}$. It is continuously discussed whether NCGS is a separate entity from "ordinary" IBS with food (gluten) dependent symptoms 36,54 , 120

\section{Epidemiology}

Accurate figures of NCGS prevalence do not exist due to the lack of well-defined objectively verifiable diagnostic criteria. Estimates are therefore given as the proportion of people who self-report gluten or wheat sensitivity or the proportion of people on gluten-free diet without having coeliac disease. The figures range from $0.6 \%$ to $13 \%\left({ }^{34} 23,24,121-127\right)$. In the USA the prevalence of people without coeliac disease who avoid gluten increased from $0.5 \%$ in 2009 to 1.7 in $2014^{71}$. The prevalence of gluten-free diet is higher among women than among men ${ }^{23}$. Recent Italian estimates from a teenage cohort of 555 students were that $\%$ had established coeliac disease, $12 \%$ reported NCGS and $3 \%$ followed a gluten-free diet. Only $23 \%$ of the self-reported NCGS had consulted a doctor and $14 \%$ had undergone serological tests for coeliac disease ${ }^{128}$. Most of the self-reported NCGS presented with IBS-symptoms (44\%). The condition is also described in children with uncertain prevalence figures ${ }^{129,130}$. 


\section{Pathophysiology}

The pathophysiology of NCGS is unclear, and the wheat components that are responsible for the development of symptoms have not been clearly defined. Table 3 presents the different biomarkers used to diagnose coeliac disease and how the same markers are unreliable for NCGS. Possible mechanisms have included innate and adaptive immune activation, impaired intestinal epithelial barrier and changes in microbiome. Negative serology for specific antibodies and lack of association with HLA-DQ2/DQ8 suggest a limited involvement of adaptive immune mechanisms in NCGS ${ }^{131}$. A higher expression of toll-like receptors in intestinal mucosa as compared to coeliac disease patients, have indicated a stronger role of innate immune mechanisms in NCGS ${ }^{131}$. Experimental studies have repeatedly shown increased IEL changes in intestinal permeability and some cytokine response after gluten challenge, but all findings have to date been considered unreliable as diagnostic biomarkers ${ }^{131-}$ 133

Table 3 Gluten sensitivity tests

\begin{tabular}{lll}
\hline Diagnostic tools & Coeliac disease & Non-coeliac gluten sensitivity \\
\hline $\begin{array}{c}\text { Coeliac disease serology } \\
\text { Anti-tissue transglutaminase }\end{array}$ & Positive & Positive/negative \\
\multicolumn{1}{c}{ Anti-gliadin antibodies } & Positive & Positive/negative \\
Anti-endomysial antibodies & Positive & Negative \\
$\quad \begin{array}{l}\text { Anti-deamidated gliadin } \\
\text { peptide antibodies }\end{array}$ & Positive & Negative \\
$\begin{array}{l}\text { Duodenal histology } \\
\text { HLA-DQ2/DQ8 }\end{array}$ & Positive (Marsh 2-3) & Negative (Marsh 0-1) \\
IgE-based assays & Present & Absent/present \\
Clinical features & Negative & Negative \\
& Troubles caused by ingestion of & Troubles caused by ingestion of \\
& wheat and their disappearance on & wheat and their disappearance on \\
& gluten-free diet & wheat/gluten-free diet \\
\hline
\end{tabular}

Table 4 summarises some of the findings related to suggested possible mechanisms in the pathogenesis of NCGS. Increased intestinal permeability in NCGS as compared with healthy controls has been reported by several research groups ${ }^{131,134}$. Hollon et al demonstrated greater increase in intestinal permeability in NCGS and coeliac disease after gliadin exposure than in coeliac disease remission ${ }^{134}$. According to Sapone et al the expression of the innate immunity marker Toll-like receptor 2 was increased in NCGS as compared to coeliac disease, and expression of a T-regulatory cell marker was significantly reduced in NCGS relative to controls and coeliac disease individuals ${ }^{131}$. The authors suggest an important role of the innate immune system without any involvement of the adaptive immune response. Di Sabatino et al. investigated innate and adaptive immunity in selfreported NCGS versus coeliac disease and found no abnormal mucosal immune response in individuals with NCGS ${ }^{135}$. A Norwegian study comparing coeliac disease and NCGS with healthy 
controls in an open gluten challenge found increased density of IELs before challenge and a significant increase in m-RNA for interferon- $\gamma$ after challenge in the NCGS subjects ${ }^{132}$.

Table 4 Observations of biochemical and physiological features in NCGS and IBS

\begin{tabular}{lll}
\hline Author & Observed change & Suggested dietary culprit \\
\hline Gibson et al. 2012 & $\begin{array}{l}\text { Increased water delivery and fermentable substrates } \\
\text { to the colon }\end{array}$ & FODMAP \\
Sapone et al. $2011^{131}$ & $\begin{array}{l}\text { Increased claudine 4 } \\
\text { Brottveit et al. } 2013^{132}\end{array}$ & Gluten \\
& $\begin{array}{l}\text { Increased interferon- } \gamma \text { m-RNA } \\
\text { Increased IEL compared to healthy controls }\end{array}$ & Gluten \\
Volta et al. 2011 137 & Antigliadin antibodies IgG & Gluten \\
Hollon et al. $2015^{134}$ & Increased intestinal permeability & Gluten \\
Schuppan et al. $2015^{46}$ & Stimulation of innate immune cells & ATI \\
\hline
\end{tabular}

m-RNA; messenger-ribonucleic acid, IEL; intraepithelial lymphocytes, FODMAP; fermentable oligo-, di-, monosaccharides and polyols, ATI; $\alpha$-amylase trypsin inhibitor

\section{Diagnostics}

A subject with suspected NCGS may present with either or both gastrointestinal and extra intestinal symptoms similar to coeliac disease. The investigation starts with adequately exclusion of coeliac disease, as shown in Figure 7, preferably before any dietary changes have been done ${ }^{133,138}$. However, many individuals with self-reported gluten sensitivity have started gluten-free diet without proper examinations. In such cases, HLA-DQ2/DQ8 positive individuals predisposed to coeliac disease should be subjected to a gluten challenge followed by a gastroscopy. An adequate amount of dietary gluten exposure is required to have a reliable duodenal biopsy. A daily intake of four slices of bread for four weeks induce diagnostic changes in duodenal biopsy ${ }^{18}$. The duration of the challenge is a compromise of the 2-8 weeks suggested in the guidelines. However, reluctance to gluten challenge because of a fear of relapse of symptoms often hampers the investigation of coeliac disease. The result is individuals on gluten-free diet with unsettled diagnosis. If, however, the exclusion of coeliac disease is made by either negative HLA-DQ2/DQ8 and/or negative duodenal biopsy while on a sufficient amount of dietary gluten, the workup continues in a collaboration between a dietitian and a gastroenterologist. It includes a thorough diet and symptom history to exclude non-gluten triggers, and continues with a standardised gluten challenge and symptom recording. This is a purely clinical approach based on symptom generation as response to a standardised open or blinded challenge. In 2015, a panel of clinicians and researchers published a non-scientific recommendation on how NCGS should be diagnosed. It included a standardised DBPCFC and $\geq 30 \%$ change of symptoms as response to the gluten challenge ${ }^{139}$. 


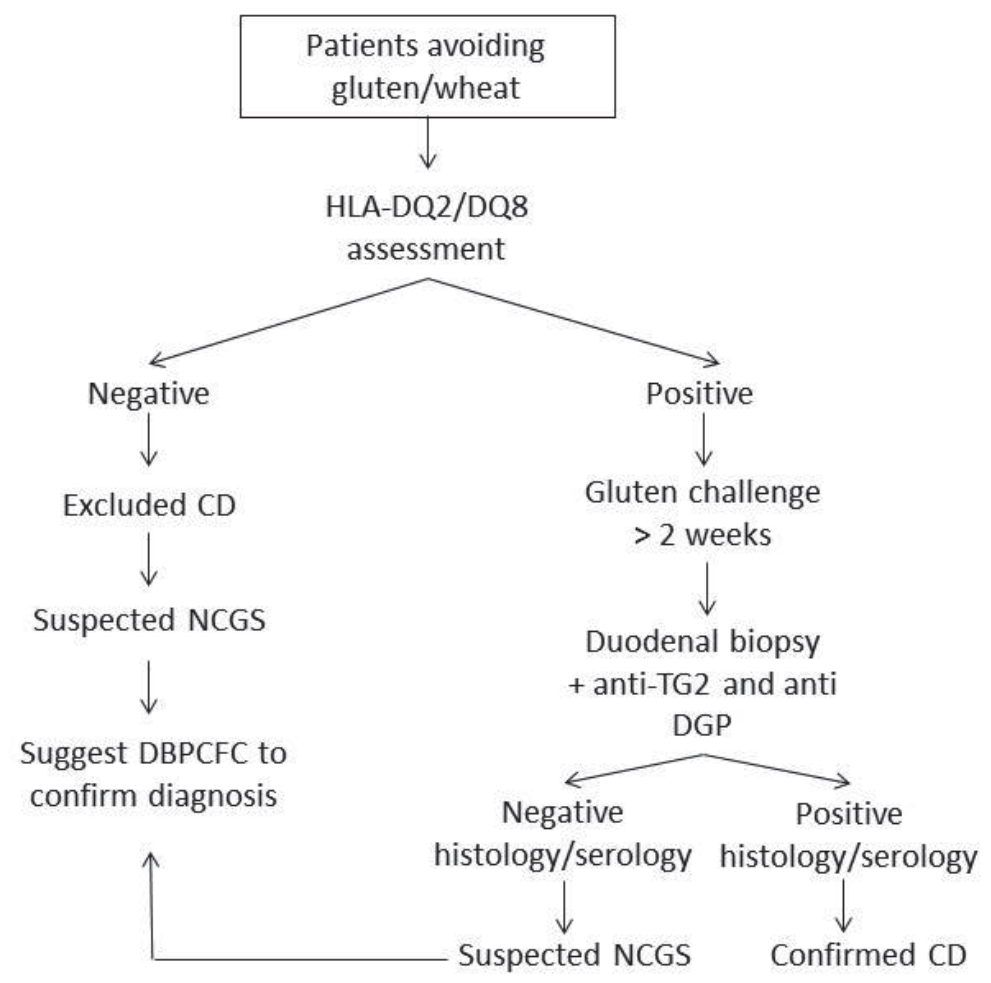

Figure 7 Suggested algorithm for the workup of non-coeliac gluten sensitivity (NCGS) adapted from Volta $2017^{133}$. HLA; human leukocyte antigen, DBPCFC; double-blind placebo-controlled food challenge, TG2; anti-tissue transglutaminase 2, DGP; deamidated gliadin-peptide.

\section{Dietary management}

Gluten-free diet has been adopted by individuals with self-reported NCGS, and some studies have described how the diet is applied by this population ${ }^{127,140,141}$. Tavakkoli et al. observed that $50 \%$ of NCGS on gluten-free diet avoided additional food ${ }^{141}$. Zingone et al. identified that fruit, vegetables, milk and dairy products were frequently avoided foods in addition to the gluten exclusion ${ }^{140}$. A Dutch study found that $74 \%$ of NCGS patients on gluten-free diet reported abdominal discomfort related to at least one high FODMAP containing food as compared to $22 \%$ of the controls ${ }^{127}$. Studies of the nutritional quality of gluten-free diet in NCGS have found lower intake of protein, fiber and polyunsaturated fatty acids in NCGS patients as compared to healthy controls ${ }^{140}$. No studies have until now described how a non-coeliac group complies to the gluten-free diet as compared to individuals with coeliac disease. 


\subsection{Gluten-free diet}

The only current treatment option for coeliac disease is strict, lifelong gluten-free diet, which usually results in mucosal healing ${ }^{60,142}$. The treatment also aims to correct immunological abnormalities, minimize symptoms and reverse protein-energy deficiency and abnormal bone health ${ }^{143}$. With adherence to the gluten-free diet the therapeutic goals can be achieved in almost all patients with coeliac disease within five years after diagnosis ${ }^{143}$.

As soon as the coeliac disease diagnosis is confirmed, a referral to a coeliac disease-trained dietitian for education in gluten-free diet is recommended ${ }^{144-146}$. First, the dietitian educates in how to keep the diet free from gluten. Second, the focus is how to keep food diversity and nutritional value in a restricted diet. Addressed issues are balanced meal planning, fibres and enrichments, hidden gluten sources and label reading ${ }^{117}$.

Gluten-free diet is based on the elimination of the alcohol-soluble protein fractions of gliadin in wheat, secalin in rye and hordein in barley, that are all toxic in coeliac disease. The cereals are replaced by gluten-free cereals such as rice, corn, buckwheat and millet. Moreover, some leguminosae such as quinoa, amaranth and soybean are particularly useful due to their high protein content quality as replacements for their gluten containing analogues ${ }^{147}$. Oats that are not contaminated with wheat (after a dedicated supply chain and manufacturing) have shown to be safe in a gluten-free diet in coeliac disease and are both allowed and recommended as part of gluten-free diet in most countries ${ }^{148-}$

${ }^{150}$. A diet mainly based on naturally gluten free cereals and non-processed food (meat, fish, poultry, egg, fruit and vegetables) facilitate gluten-free diet adherence and secure the nutritional value of the diet.

However, any restrictive diet is at risk of nutritional inadequacy. Previous studies have generally but not always found the gluten-free diet to be nutritionally inadequate ${ }^{151-153}$. Some deficiencies are related to habitual poor food choices, and some to inherent deficiencies of gluten-free diet. A study of Australian coeliac disease patients found that inadequacies of folate, calcium, iron and zinc were more frequent than in the general population ${ }^{154}$. Gluten-free diet may have negative social, financial and health consequences, and some authors have advised against a life-long diet for individuals without coeliac disease ${ }^{155}$. 


\subsection{Diet low in FODMAP}

A diet low in FODMAP has shown to be a successful approach in the management of symptoms in IBS ${ }^{98,156-158}$. It was first suggested as a new approach to Crohns Disease in Australia about 12 years ago and is now an internationally accepted dietary strategy for IBS ${ }^{159,160}$. The dietary management is a dietitian-driven education process containing 6-8 weeks where foods rich in FODMAP are restricted (Figure 8). The elimination phase is followed by a standardised reintroduction phase ${ }^{158}$.

FODMAP have small molecular size that exerts an intestinal osmotic effect leading to increased delivery of water to the colon ${ }^{53,161}$. In the colon, fermentation of the short-chain fermentable carbohydrates results in the production of short-chain fatty acids such as acetate, propionate and butyrate, and gases such as carbon dioxide and methane ${ }^{136,162}$. These by-products contribute to growth and functioning of the gut microbiota ${ }^{12,163}$. In susceptible individuals, distension of distal small and proximal large bowels by rapid gas production and the additional fluid load may induce gastrointestinal symptoms such as pain, bloating and altered bowel habit ${ }^{136}$. Studies of various designs

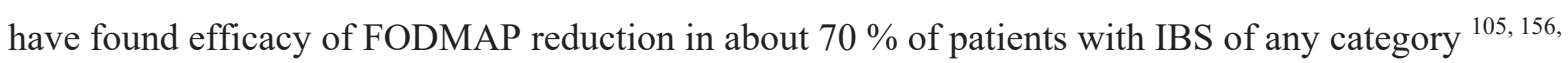
157, 164-166. The concept is now implemented as a treatment option in the up-dated guidelines from National Institute for Health and Clinical Excellence ${ }^{103}$.

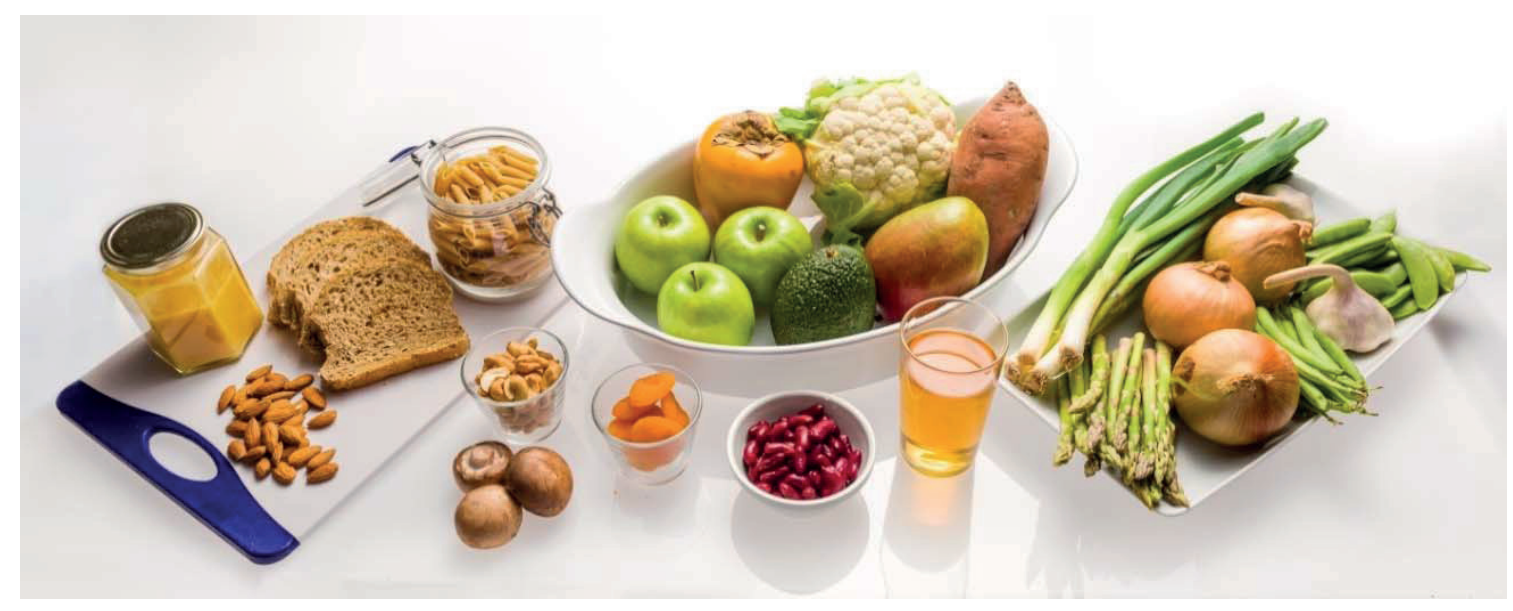

Figure 8 FODMAP exist in a variety of foods (Photo: Øystein H. Horgmo, University of Oslo). FODMAP; fermentable oligo-, di-and monosaccharides and polyols. 


\subsection{Knowledge gaps}

Symptom relief and health benefits have motivated non-coeliac people to institute a gluten-free diet. Patients with coeliac disease are educated in strict diet adherence. However, little is known about diet adherence in non-coeliac patients that are mostly self-instituted on the gluten-free diet. Further, the gluten exposure during gluten-free diet has never been estimated in this patient group.

In 2009-2015 Oslo University Hospital used a standardised open bread challenge to assess NCGS in a clinical setting. The classification of NCGS or non-NCGS was performed by a gastroenterologist based on clinical interview and symptoms scores, but without any predefined standard for symptoms change. For the first time, standardised cut-offs for symptom change in investigation of NCGS were published by a panel of researchers and clinicians in 2015. These standards have never been applied to the Norwegian patient material, or any other patient group.

Proper exclusion of coeliac disease is crucial in the clinical investigation of NCGS. A major problem with the assessment of NCGS is that self-reported gluten-sensitive subjects often institute a gluten-free diet without adequate workup for coeliac disease. If symptom relief has been achieved in response to the gluten-free diet, subjects may be reluctant to gluten exposure for diagnostic purpose. To overcome this problem, recent guidelines suggested gluten exposure of two weeks as a minimum, and up to eight weeks in order to have a reliable duodenal biopsy ${ }^{18}$. However, the minimum of two weeks of gluten exposure before gastroscopy has not been well validated ${ }^{72}$.

The culprit of symptoms in NCGS is not clearly defined. Thus, the pathogenesis remains unclear. Some studies have found increase of symptoms in response to gluten challenge, and symptom relief in response to gluten removal. However, alteration of the gluten content of the diet has effects on dietary constituents in addition to gluten. The studies have failed to show that symptom improvement has been due to the gluten removal per se, and overlooked the presence of other components with proven pathogenic capabilities, such as the poorly absorbed FODMAP and in particular the wheat fructans. Fructan challenge has never been done in self-reported gluten sensitive subjects without coeliac disease. 


\section{AIMS}

The overall aim was to study gluten-free diet in NCGS, evaluate diagnostic methods in coeliac disease and NCGS and to study symptom triggers in NCGS. The specific aims of the papers were as follows:

\section{Paper I}

To assess and compare diet adherence and gluten exposure in subjects with coeliac disease and subjects with self-reported NCGS.

\section{Paper II}

To compare the results of an open bread challenge in patients suspected of having NCGS in the period 2009-2015 with recently suggested definitions of symptom change.

\section{Paper III}

To investigate whether a 14-day gluten challenge is enough to invoke villous blunting in well-treated subjects with coeliac disease, and to study whether the diagnostic sensitivity of a short gluten challenge can be improved by applying other methods and biomarkers.

\section{Paper IV}

To investigate the effect of gluten and fructans separately by a randomised double-blind placebocontrolled crossover challenge in subjects with self-reported gluten sensitivity and in whom coeliac disease and wheat allergy were adequately excluded. 


\section{METHODS}

\subsection{Design and participation}

Table 5 shows an overview of the samples and the types of studies in the four papers. The following sections will describe the study sample and study design of each of the papers.

Table 5 Overview of study samples and designs in papers I-IV

\begin{tabular}{clll|l}
\hline Paper & Subjects & n & Type of study & Recruitment \\
\hline I & $\begin{array}{l}\text { Coeliac disease } \\
\text { NCGS }\end{array}$ & 23 & Cross-sectional & $\begin{array}{l}\text { Oslo University Hospital: patient referrals } \\
\text { Norwegian Coeliac Society: advertisements } \\
\text { Newspaper advertisements }\end{array}$ \\
\hline II & NCGS & 56 & Cross-sectional & Oslo University Hospital: patient referrals \\
\hline III & Coeliac disease & 19 & $\begin{array}{l}\text { Uncontrolled } \\
\text { intervention }\end{array}$ & $\begin{array}{l}\text { Oslo University Hospital: advertisements and } \\
\text { patient referrals } \\
\text { Norwegian Coeliac Society, Facebook: } \\
\text { advertisements }\end{array}$ \\
\hline IV & NCGS & 59 & $\begin{array}{l}\text { Randomised } \\
\text { clinical trial }\end{array}$ &
\end{tabular}

NCGS, non-coeliac gluten sensitivity

\subsubsection{Paper I}

The data of paper I was obtained from a previous study consisting of subjects with confirmed coeliac disease and subjects with self-reported gluten sensitivity, aged 17-65 years and recruited in the period 2009-2010. Participant flow is described in detail elsewhere ${ }^{167}$. The self-reported gluten sensitive subjects had not previously been properly investigated for coeliac disease. During the follow up three of these were diagnosed with coeliac disease ${ }^{167}$. However, in paper I this gluten sensitive cohort is referred to as NCGS subjects. One coeliac disease subject and one NCGS subject were reluctant to be interviewed about their diet. Thus, 23 coeliac disease subjects and 34 NCGS subjects were included in the study. 


\subsubsection{Paper II}

\section{Open bread challenge}

The open bread challenge described in paper II was a clinical tool for the investigation of patients suspected of having NCGS referred to Oslo University Hospital in the period 2009-2015, a collaboration between Department of Gastroenterology and Division of Clinical Nutrition (Figure 9). A dietitian carried out nutrition assessment and a standardised dietary history. Patients then underwent a 3-14 days open challenge of four slices of white bread (120 g) per day. Symptom recordings were returned to the dietitian who calculated symptom scores. The gastroenterologist evaluated the individual challenge response and concluded positive or negative diagnosis of NCGS, without any predefined cut-off for symptom change. The diagnosis was used by the patients when they applied for reimbursement for gluten-free food (as defined by National Administration of Labour and Welfare) ${ }^{168}$.

The bread was purely wheat based and patients were instructed to buy a certain brand of sandwich bread from the food store (Sandwhich bread or Paagen Sandwhich). Retrospective analysis showed that 100 grams of white bread contained $6.8 \mathrm{~g}$ of gluten and $2.1 \mathrm{~g}$ of fructans.

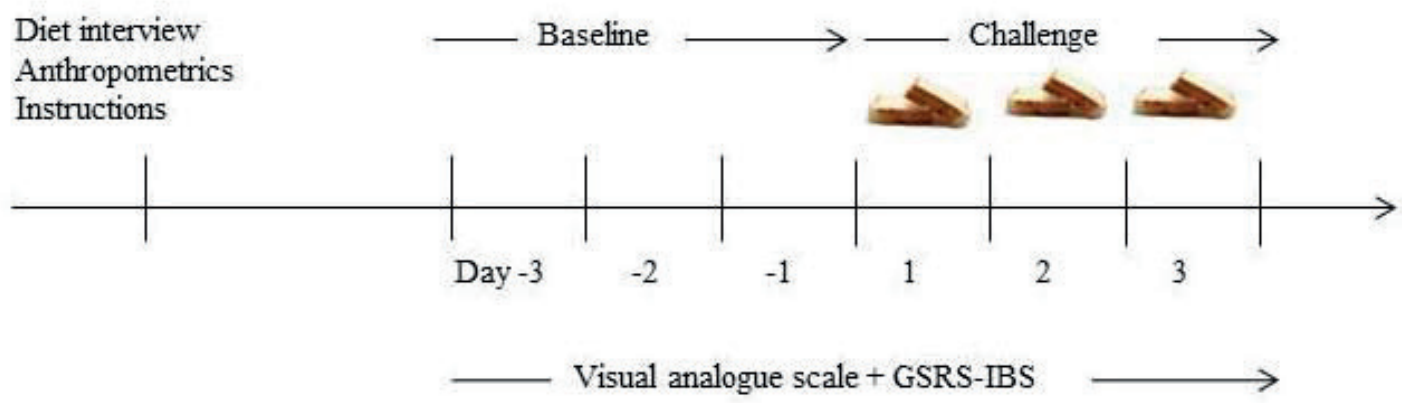

Figure 9 Outline of open bread challenge of paper II. 


\section{Study sample paper II}

The study sample of paper II were subjects aged 17-75 years that had been referred to the Oslo University Hospital, Department of Gastroenterology's outpatient clinic with suspicion of NCGS. The subjects underwent an open bread challenge in the period 2009-2015. Dietitian's and clinician's reports were analysed from medical records composing a retrospective quality control study. The subject flow is given in Figure 10.

The subjects were self-instituted on gluten-free diet followed by self-reported symptom relief. Coeliac disease was considered ruled out if clinical history showed normal duodenal biopsy while on a glutencontaining diet, or if the coeliac disease compatible genotypes HLA-DQ2.5 or-DQ8 were negative. Subjects with clinically defined wheat allergy were considered not suitable for challenge.

Of 63 subjects referred for NCGS in the given period, 56 (44 women) completed the open bread challenge protocol with either GSRS-IBS or VAS recordings. Both measures were recorded in 42 subjects.

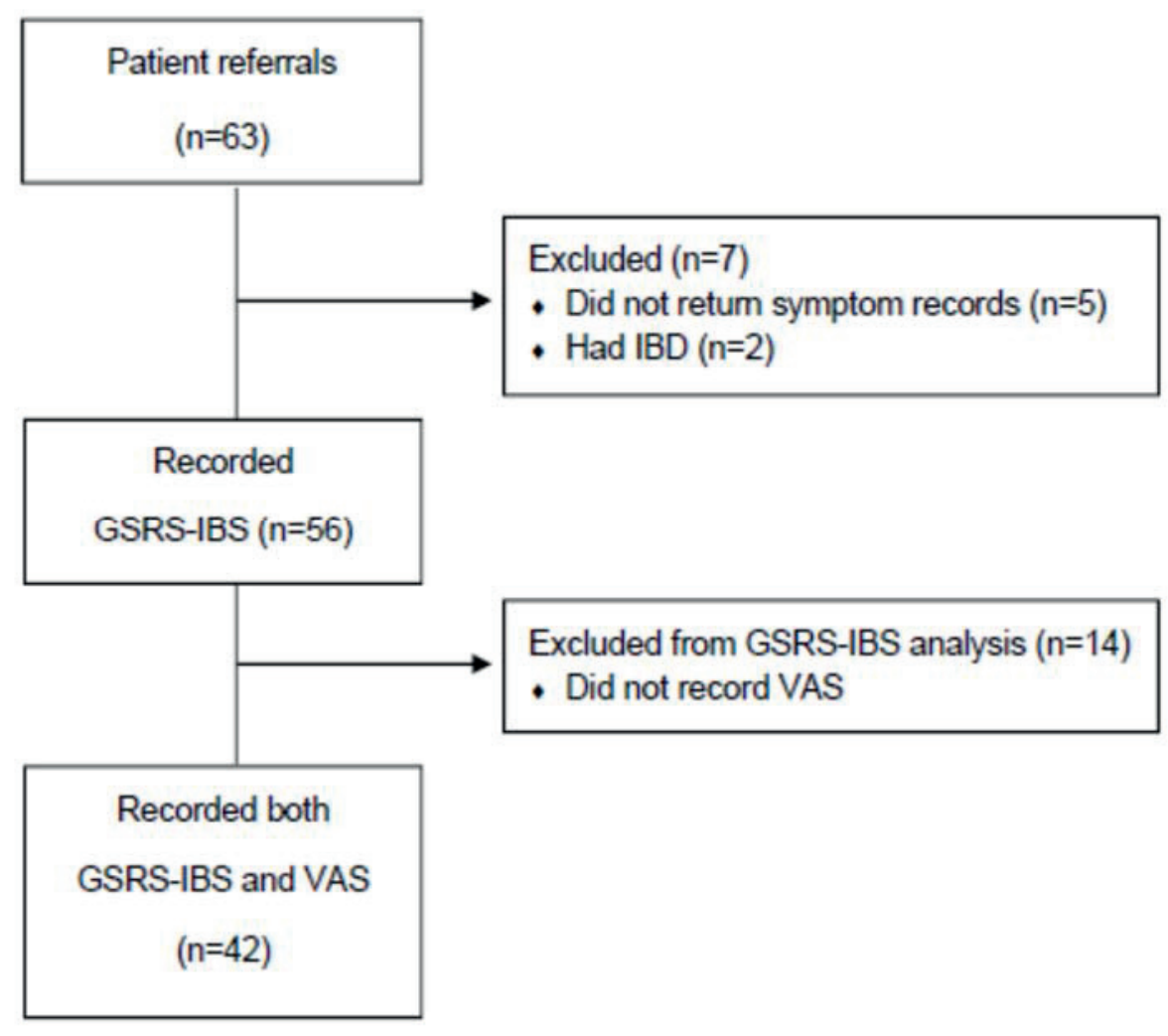

Figure 10 Flowchart of subjects in paper II. GSRS-IBS, Gastrointestinal Symptom Rating ScaleIrritable Bowel Syndrome version, VAS, visual analogue scale. 


\subsubsection{Paper III}

\section{Open gluten challenge}

Figure 11 shows the time line of the open 14 days gluten challenge of coeliac disease subjects of paper III. The subjects ingested a muesli bar containing $5.7 \mathrm{~g}$ of gluten once daily (Figure 12). The same gluten muesli bar was used in the challenge of the NCGS subjects in paper III. Apart from the glutencontaining muesli bar, the subjects continued their regular gluten-free diet. They underwent the first day of gluten challenge under medical supervision.

Day 1 - 14: Challenge with 5.7 g. gluten daily

\begin{tabular}{|c|c|c|c|c|c|}
\hline Baseline & Day 1 & Day 6 & Day 7 & Day 14 & Day 28 \\
\hline Blood samples & Clinical & Blood & Question- & Blood samples & Blood \\
\hline Patient story and & examination & samples & naires. & Questionnaires & samples \\
\hline questionnaires & Blood & & & Gastroscopy & \\
\hline Informed consent & samples & & & & \\
\hline Gastroscopy & & & & & \\
\hline
\end{tabular}

Figure 11 Outline of the challenge study of paper III.

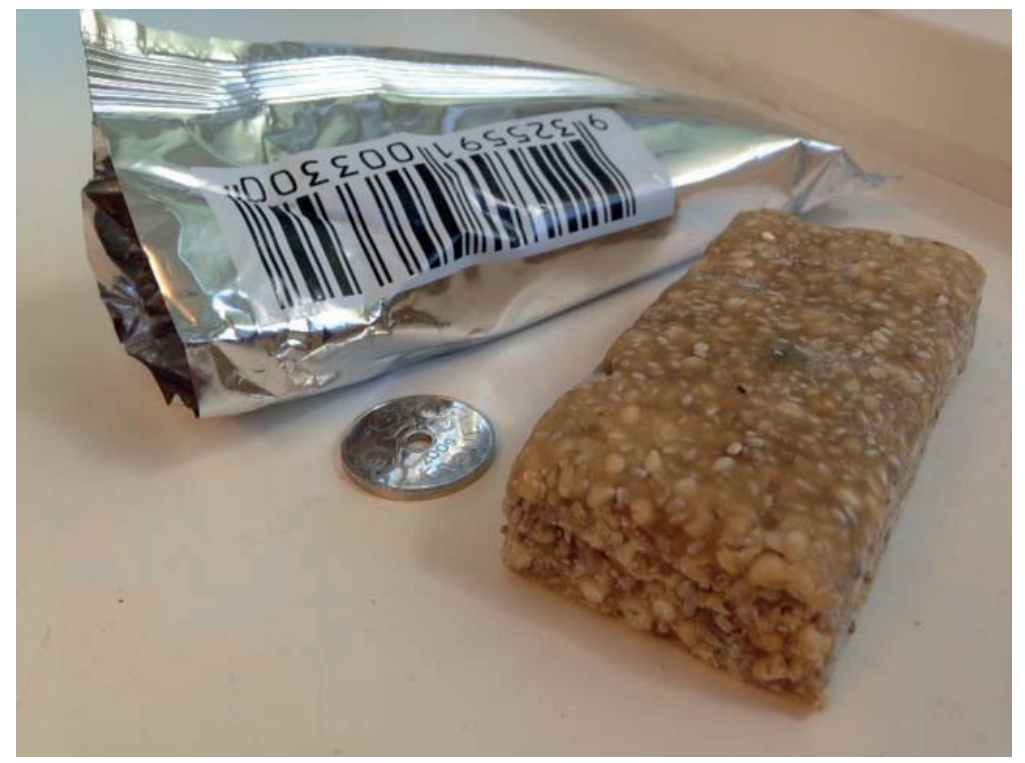

Figure 12 Quinoa-based muesli bar as challenge vehicle in the study of paper III and IV. 


\section{Study sample of paper III}

Figure 13 shows how 78 subjects aged 18-80 years were screened according to the following criteria in the study of paper III:

Inclusion criteria:

- Coeliac disease verified by either positive biopsy or positive serology before start of glutenfree diet if biopsy is yet not done and is expected to be positive after a challenge.

- Strict adherence to gluten-free diet for at least the last six months.

Exclusion criteria:

- Pregnancy or lactation.

- Women of fertile age not taking adequate contraceptive measures.

- Use of immunosuppressive medication for the last three months.

- Chronic or severe acute infection.

- Allergy to sesame seeds, pecan or macadamia nuts.

- Positive anti-transglutaminase $2 \operatorname{IgA}$ or duodenal biopsy (Marsh 2 or 3) at baseline.

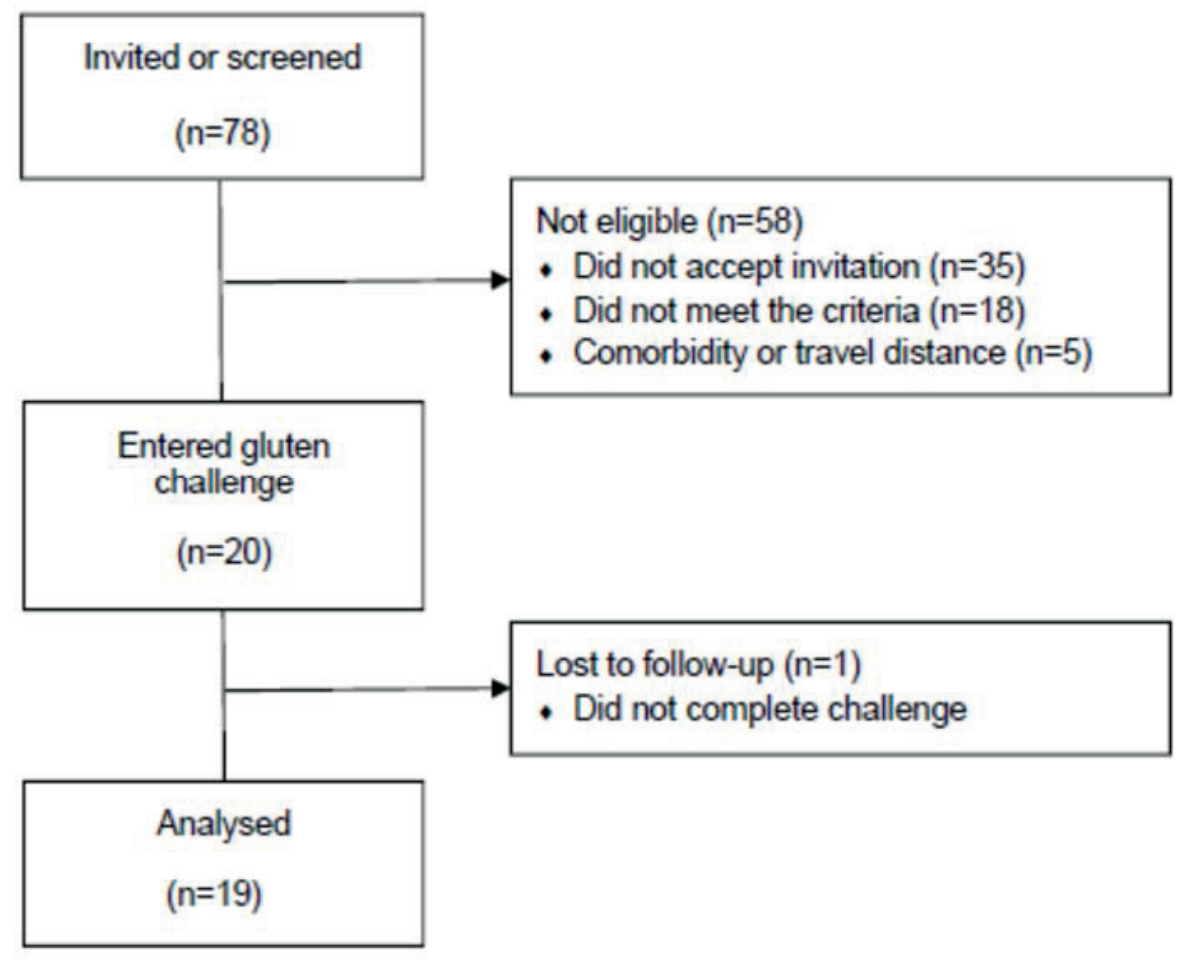

Figure 13 Flowchart of subjects in paper III. 


\subsubsection{Paper IV}

\section{Blinded gluten and fructan challenge}

The study of paper IV was a randomised clinical trial (RCT). Figure 14 shows the design of the randomised, double-blind, placebo-controlled, crossover study with three periods and six sequences $(\mathrm{ABC} / \mathrm{ACB} / \mathrm{BAC} / \mathrm{BCA} / \mathrm{CAB} / \mathrm{CBA})$. Each challenge appeared the same number of times within each period and sequence. Further, the crossover design was balanced so that each challenge preceded every other challenge the same number of times.

Baseline information was obtained in an interview based on a standardised clinical report form (Appendice). Baseline diet and symptoms were recorded during a seven-day period before start of challenge. They were then randomised to one of the six sequences of the seven-day challenges by gluten, fructan and placebo, followed by a minimum of one-week washout period. Washout periods were extended until the symptoms from previous challenge were resolved. All subjects and study team members were blinded throughout the study. Details of randomisation and blinding are described in paper IV.

The challenge vehicle was a quinoa-based $50 \mathrm{~g}, 220 \mathrm{kcal}$ low-FODMAP gluten-free muesli bar that was eaten once daily (Figure 12). The muesli bars were developed and produced by the Monash University, Australia. They were balanced in carbohydrates, fibre, fat and protein and had similar appearance, texture and taste. The fructan bar was added $2.1 \mathrm{~g}$ of fructo oligosaccharides (Orafti ${ }^{\circledR}$ Oligofructose) and the gluten bar $5.7 \mathrm{~g}$ of gluten. The gluten was commercially available, carbohydrate depleted wheat gluten (Vital Wheat Gluten, Manildra Group, Gladesville, New South Wales, Australia).

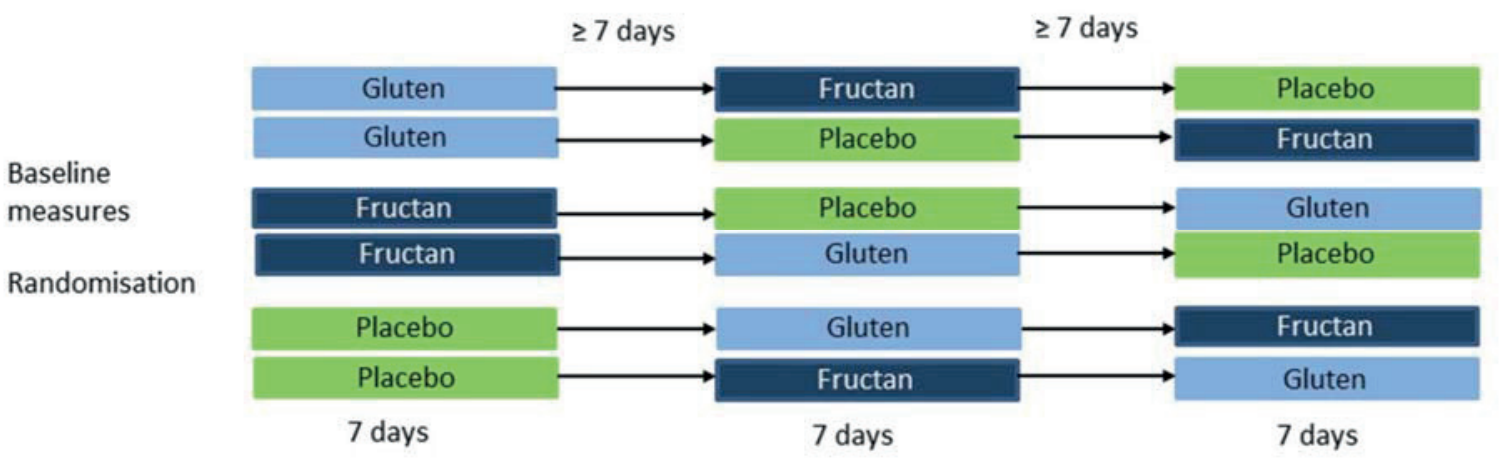

Figure 14 Crossover design of the study in paper IV. 


\section{Study sample of paper IV}

The subjects of paper IV were adults aged 18-80 years with self-reported gluten sensitivity recruited to a randomised clinical trial at Oslo University Hospital from October 2014 to May 2016 according to the following inclusion criteria:

- Strict adherence to gluten-free diet for at least the last six months.

- Reported and measured symptom relief of gluten-free diet.

- Coeliac disease excluded by normal duodenal biopsy while on gluten-containing diet or absence of the genotype HLA-DQ2/8.

- Wheat allergy excluded by negative wheat specific IgE.

Exclusion criteria were:

- Pregnancy or lactation.

- Use of immunosuppressive medication for the last three months.

- IBD or other comorbidity.

- Chronic or severe acute infection.

- Women of fertile age not taking adequate contraceptive measures.

- Allergy to sesame seeds, pecan or macadamia nuts.

Of 232 subjects assessed, 68 were found eligible (Figure 15). Of the excluded, 111 subjects did not meet the inclusion criteria: coeliac disease properly excluded $(n=61)$, long travel distance $(n=20)$, not gluten-free $(n=21)$ or symptomatic on gluten-free diet $(n=4)$. Two subjects were excess according to the predefined 66 subjects needed, thus two extra sequences were made by an external dietitian and kept double blinded. The subjects chose to proceed from baseline and completed the protocol, but were told from the start that they would be excluded from the statistical analysis. Three more subjects were excluded from analysis because of late discovery of coeliac disease related finding of the baseline measures. One had duodenal biopsy of Marsh 3 despite gluten-free diet and former negative biopsy on gluten containing diet. Two had positive HLA-DQ2/8 genotype in blood tests without any further exclusion of coeliac disease. The remaining 59 subjects completed all three challenges and were included in the analysis. 


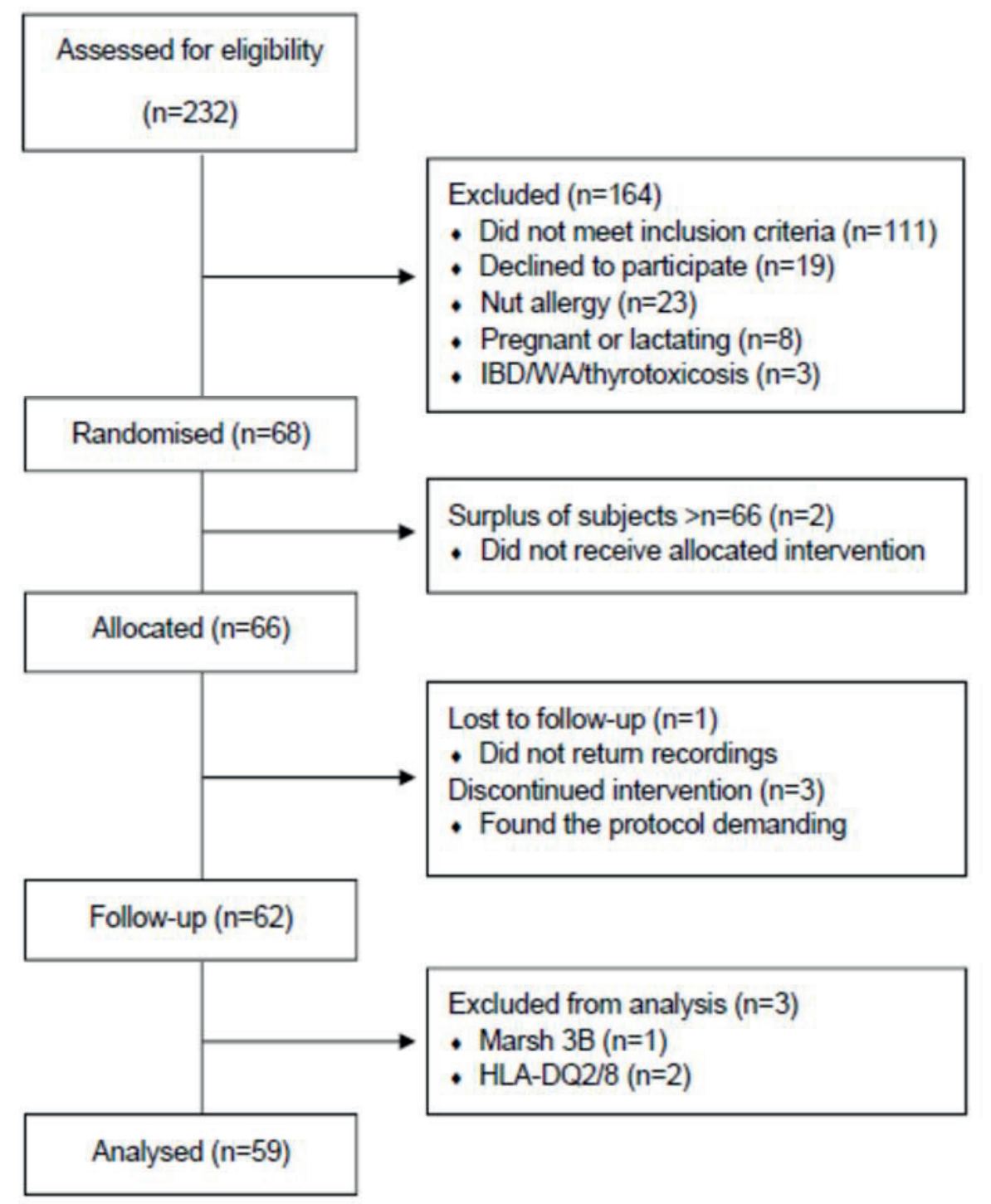

Figure 15 Flowchart of subjects in paper IV. IBD, inflammatory bowel disease, WA, wheat allergy, HLA, human leukocyte antigen 


\subsection{Dietary assessment}

Dietary assessment was performed in paper I and IV. After thorough instruction, subjects were asked to record their food intake by a three-day weighed food record (paper I) and by seven-day dietary record (paper IV), (Table 6). They were told to maintain their usual gluten-free diet and to record recipes and the names of all products consumed.

In paper I underreporting of food intake was assessed by calculated energy intake and calculated basal metabolic rate (BMR). A BMR-factor (energy intake/BMR-ratio) less than 1.47 was considered as underreported food intake ${ }^{169}$.

In paper IV, sources of FODMAP were extracted from the seven-day dietary record and the intake of fructans and total FODMAP was calculated using the nutrition software Foodworks, Version 7 (Xyris Software Australia Pty Ltd, Highgate Hill, QLD, Australia).

Table 6 Dietary assessment methods used in the thesis

\begin{tabular}{lll}
\hline & $\begin{array}{l}\text { Record by weighing } \\
\text { Paper I }\end{array}$ & $\begin{array}{l}\text { Record by household measures } \\
\text { Paper IV }\end{array}$ \\
\hline Description & All food and beverages consumed & All food and beverages consumed \\
& weighed and recorded & recorded by household measures \\
Duration & 3 consecutive days including & 7 consecutive days \\
& Saturday or Sunday & \\
Equipment & Household scale & Picture booklet of portion sizes \\
\hline
\end{tabular}

\subsection{Gluten-free diet adherence}

In paper I adherence to gluten-free diet was assessed by interviewing the subjects about their meal situation, and their use of gluten-free and naturally gluten-free products, by means of a frequency questionnaire and additional standardised questions related to diet understanding and diet practice. The dietitian then categorized the adherence into one of four categories given in Table 7. Reported intakes of regular food used less frequently than once a month, were not included in the calculations of gluten exposure. Energy intake was calculated by means of the Norwegian Food Composition Table (www.matvaretabellen.no).

In paper IV, diet adherence was measured by using a locally developed and unpublished selfadministered questionnaire based on information from focus groups and the coeliac disease adherence 
test (CDAT) (Appendice) ${ }^{170}$. The questionnaire contained eleven questions with a Likert scale of 1-5 where lower scores indicated good adherence.

Table 7 Categories of adherence to gluten-free diet

\begin{tabular}{ll}
\hline Good & $\begin{array}{l}\text { Intake of always known gluten-free food at home and away from } \\
\text { home, always checking of labels, no voluntary transgression }\end{array}$ \\
Fair & $\begin{array}{l}\text { Possible risks like less checking of ingredients, no asking for } \\
\text { ingredients in menus when eating out }\end{array}$ \\
Poor & Additional obvious risks like consuming food of unknown \\
& composition, tasting of gluten containing food or having regular \\
beer weekly or more frequently & Eating regular meals in certain periods, occasions (i.e.vacations, \\
Non-adherent & \\
&
\end{tabular}

\subsection{Prolamin and fructan analyses}

In paper I, a substantial sampling of selected gluten-free and gluten-containing foods was done from regular food markets and special food stores in central parts of Oslo. The samples were analysed by the sandwich R5-ELISA Ridascreen ${ }^{\circledR}$ Gliadin competitive method (Art. No.R7011 and Art. No.R7021). Non-detectable concentrations were set at less than $5 \mathrm{mg}$ gluten $/ \mathrm{kg}$. The mean of the duplicate gluten values was applied for the calculations of gluten exposure.

The muesli bars used in the study of paper III and IV were analysed with the same method to confirm the presence and amount of gluten in the gluten containing muesli bar, and absence of it in the fructan and placebo bar. Further, the presence of 33-mer peptides in the gluten containing muesli bar and their absence in the placebo muesli bar were confirmed by mass spectrometry and label free quantification (The Proteomics Core Facility, Department of Immunology and Transfusion Medicine, Oslo University Hospital, Oslo, Norway).

The content of fructans in the muesli bar was set to mimic the amount of fructans in four slices of white bread, as used in the open challenge of paper I. White bread were sampled, extracted and freezedried according to a standardised sampling procedure ${ }^{49}$. The samples were sent to the Monash University and analysed by the Megazyme Fructan HK kit and high performance liquid chromatography ${ }^{55}$. 


\subsection{Coeliac disease morphology and serology}

In the study of paper III gastroduodenoscopy was done at baseline and repeated on day 14 of gluten challenge in the coeliac subjects. Mucosal remission status at baseline was initially determined by non-blinded routine biopsy assessment. An experienced gastrointestinal pathologist performed the morphometric measurements, cell counting and establishment of Marsh scores, blinded for participant identity and study visit ${ }^{171}$. Mean villous height by crypt depth ratio and quantification of IEL was performed. An IEL-count of 25 per 100 enterocytes was used as cut-off between Marsh scores 0 and $1^{63}$.

Measurement of anti-TG2-IgA and anti-DGP-IgG was done at baseline and repeated in the coeliac subjects on day 6,14 and 28 after start of challenge. Gluten-specific T-cells binding to HLADQ:gluten tetramers were analysed by flow cytometry at baseline and on day 6 of gluten challenge in the coeliac subjects.

\subsection{Patient reported outcome measures}

Recording of symptoms was performed in paper II-IV. Gastrointestinal symptoms were the primary outcome measure in paper II. In paper IV the subjects recorded both gastro- and extra intestinal symptoms. In all the studies self-administered questionnaires were used. The selection of symptoms and questionnaires reflected the clinical characteristics of NCGS described in the literature ${ }^{121,122,172}$ and which methods that were already applied for similar patients in clinical and scientific settings at Oslo University Hospital ${ }^{132,}{ }^{173}$. In paper III a coeliac disease specific questionnaire was used ${ }^{174}$. Table 8 presents an overview of the patient reported outcome measures.

\section{Visual analogue scale (VAS)}

In paper II-IV gastrointestinal symptoms were additionally measured daily using a $100 \mathrm{~mm}$ visual analogue scale (VAS). The method is widely used to record subjective symptoms in challenge studies of IBS and NCGS ${ }^{107,119}$ and in clinical and scientific investigation of food allergies and intolerances (Appendices) ${ }^{175,176}$. VAS was used to measure abdominal pain, bloating, passage of wind, nausea, stool dissatisfaction and overall symptoms (papers II-IV). Further, extra intestinal symptoms often reported in NCGS literature; numbness and tingling in hands and feet, concentration problems and pain in joints and muscles were recorded by VAS (Table 8) ${ }^{24,111,122}$. Finally, the six fatigue complaints were also recorded using VAS. 
Table 8 Overview of patient reported outcome measures used in the thesis

\begin{tabular}{|c|c|c|c|c|c|c|}
\hline Category & Name & Items (n) & Score & $\begin{array}{l}\text { Cut- } \\
\text { off/norm. } \\
\text { data } \\
\end{array}$ & Implication & Paper \\
\hline \multirow[t]{6}{*}{$\begin{array}{l}\text { Gastrointestinal } \\
\text { symptoms }\end{array}$} & \multirow[t]{6}{*}{$\begin{array}{l}\text { GSRS- } \\
\text { IBS }^{177}\end{array}$} & Total items (13) & $13-91$ & None & \multirow[t]{6}{*}{$\begin{array}{l}\text { High score- } \\
\text { more symptoms }\end{array}$} & \multirow[t]{6}{*}{$\begin{array}{l}\text { II, III, } \\
\text { IV }\end{array}$} \\
\hline & & Pain (2) & $2-14$ & & & \\
\hline & & Bloating (3) & $3-21$ & & & \\
\hline & & Constipation (2) & $2-14$ & & & \\
\hline & & Diarrhea (4) & $4-28$ & & & \\
\hline & & Satiety (2) & $2-14$ & & & \\
\hline \multirow{8}{*}{$\begin{array}{l}\text { Coeliac disease } \\
\text { symptoms } \\
\text { Fatigue }\end{array}$} & $\mathrm{CSI}^{174}$ & Total items (16) & $5-80$ & $\begin{array}{l}\leq 30 \\
\geq 45\end{array}$ & \multirow{8}{*}{$\begin{array}{l}\text { Good QoL } \\
\text { Poor QoL } \\
\text { High score - } \\
\text { more fatigue }\end{array}$} & III \\
\hline & \multirow[t]{7}{*}{$\mathrm{GBB}^{178}$} & Total items (6) & $0-24$ & & & \multirow[t]{7}{*}{ IV } \\
\hline & & Weakness (1) & $0-4$ & & & \\
\hline & & Sleepiness (1) & $0-4$ & & & \\
\hline & & Exhaustion (1) & $0-4$ & & & \\
\hline & & Tiredness (1) & $0-4$ & & & \\
\hline & & Dizziness (1) & $0-4$ & & & \\
\hline & & Fatigue (1) & $0-4$ & & & \\
\hline \multirow{3}{*}{$\begin{array}{l}\text { Anxiety and } \\
\text { depression }\end{array}$} & \multirow[t]{3}{*}{$\mathrm{HAD}^{179}$} & Total items (14) & & & & \multirow[t]{3}{*}{ IV } \\
\hline & & Anxiety (7) & $0-21$ & $\geq 8$ & Anxiety & \\
\hline & & Depression (7) & $0-21$ & $\geq 8$ & Depression & \\
\hline \multirow[t]{9}{*}{ HRQoL } & \multirow[t]{9}{*}{ SF-36 ${ }^{180}$} & Total items $(36)^{*}$ & $0-100$ & & \multirow{9}{*}{$\begin{array}{l}\text { High score- } \\
\text { high HRQoL }\end{array}$} & \multirow[t]{9}{*}{ IV } \\
\hline & & Physical functioning (10) & $0-100$ & 88.7 & & \\
\hline & & Role physical (4) & $0-100$ & 83.0 & & \\
\hline & & Role emotional (3) & $0-100$ & 84.1 & & \\
\hline & & Bodily pain (2) & $0-100$ & 74.4 & & \\
\hline & & Social functioning (2) & $0-100$ & 85.7 & & \\
\hline & & Mental health (5) & $0-100$ & 77.9 & & \\
\hline & & Vitality (4) & $0-100$ & 58.5 & & \\
\hline & & General health (5) & $0-100$ & 79.3 & & \\
\hline Any symptoms & VAS & $\begin{array}{l}\text { Pre-selected items within } \\
\text { gastrointestinal and } \\
\text { fatigue symptoms }\end{array}$ & $0-100 \mathrm{~mm}$ & & $\begin{array}{l}\text { High score- } \\
\text { more symptoms }\end{array}$ & $\begin{array}{l}\text { II, III, } \\
\text { IV }\end{array}$ \\
\hline
\end{tabular}

GSRS-IBS, Gastrointestinal Symptom Rating Scale IBS-version, CSI, Coeliac Symptom Index, GBB, Giessen Subjective Complaint List, HAD, Hospital Anxiety and Depression Scale, HRQoL, Health related quality of life, SF-36, Short Form 36 * item "Change in health" is not a real item and therefore not listed, VAS, visual analogue scale. 


\section{Comparison of symptom scoring methods}

In paper II the result of the open bread challenge was retrospectively evaluated against suggested cutoffs for symptom change. A symptom increase of $\geq 30 \%$ as response to gluten in a standardised challenge was considered as a relevant worsening of symptoms according to the Salerno experts criteria ${ }^{139}$. Furthermore, a symptom increase of $\geq 20 \mathrm{~mm}$ on VAS was considered a clinically relevant increase of symptoms when challenged to standardised gluten amount in a research setting ${ }^{119}$. These two cut-offs were applied to the results of the open bread challenges and compared by absolute and specific agreement.

\subsection{Sample size and power calculation}

The sample sizes of the study in paper I was not based on power calculation.

In paper II a retrospective power analysis was performed in Stata. Mean (SD) mm overall symptoms assessed by VAS during challenge was 67 (26) for NCGS $(n=36)$ and 41 (15) for non-NCGS $(n=6)$, and significantly different $(\mathrm{p}=0.001)$. With a significance level of 0.05 , there was $88 \%$ power to detect this difference in VAS score between 36 NCGS subjects and 6 non-NCGS subjects (Stata 14, College Station, TX: Stata Corp 2015 LP).

In paper III the sample size was based on the 20 subjects in the study by Leffler et al. ${ }^{72}$. A post-hoc sample size calculation using the primary end-point results (i.e. Marsh type 3 at end of challenge) in our study vs Leffler et al. ( 0.26 vs 0.70 with $\alpha=0.05$ and $\beta=0.20)$, revealed that a number of 17 subjects completing the study protocol would have been sufficient.

In paper IV the sample size was calculated prior to the study and was based on paired t-test of differences between two challenges within the same subject. The level of significance was set to 0.02 to account for pairwise comparisons between challenges (0.05/3). Earlier studies reported a GSRS-IBS mean difference of 1.5 units and a standard deviation of 3.2. With $80 \%$ power and a two-sided significance level of 0.02 we needed 66 subjects to detect such a difference, given an anticipated dropout of $30 \%$ and six sequences of challenges (Stata 14, College Station, TX: Stata Corp 2015 LP). 


\subsection{Statistical analysis}

Descriptive data were presented as frequencies (\%), means (SDs) or medians (IQRs) in all papers. Statistical analysis was performed using SPSS 22.0 and 24.0 in papers I, II and IV. In paper III statistical analysis was performed using GraphPad Prism 7.02. Two-sided p-values $<0.05$ were considered significant.

In paper I continuous variables were analysed by two-sample t-test or Mann Whitney U-test, and categorical variables by chi-square test.

In paper II changes in symptoms from baseline to challenge for the whole group were tested by the Wilcoxon signed rank test. The two groups, NCGS and non-NCGS, were compared by the Mann Whitney U test. Comparison between the two groups as regards sex was performed by a chi-square test. Spearman correlation coefficient was calculated to estimate the associations between the symptom scores for overall symptoms, abdominal pain and bloating by VAS and total score for GSRS-IBS and the pain and bloating dimensions. Agreement between the scoring methods was estimated by absolute agreement (the proportion of patients on the diagonal, $\mathrm{P}_{\mathrm{A}}$ ) and Kappa ( $\left.\kappa\right)$. Strength of agreement was evaluated according to the Kappa cut-offs given by Landis \& $\operatorname{Koch}^{181}$ : $=0.01 \leq \kappa \leq 0.20$ poor, $0.21 \leq \kappa \leq 0.40$ fair, $0.41 \leq \kappa \leq 0.60$ moderate, $0.61 \leq \kappa \leq 0.80$ substantial and $0.81 \leq \kappa \leq 0.99$ excellent agreement. McNemar test was used to test symmetry. Specific agreement was also calculated, expressing separately the agreement for the diagnosis of NCGS (positive agreement, $\mathrm{P}_{\mathrm{pos}}$ ) and non-NCGS (negative agreement, $\mathrm{P}_{\text {neg }}$ ) using the formulas in de Vet et al ${ }^{182}$.

In paper III normally distributed data were analysed by paired t-test or one-way analysis of variance with post-hoc Dunn's adjustment test for multiple comparisons relative to baseline. Wilcoxon signed rank test was used for non-normal paired data. Statistical analysis was done on GraphPad Prism V. 7.02 (GraphPad Software, La Jolla, California, USA) and SPSS (IBM SPSS Statistics V. 22.0, North Castle, New York, USA).

In paper IV differences between the challenge responses were analysed by linear mixed model and included multiple pairwise comparisons between challenges with Bonferroni corrections. Subjects were modelled as random with a random intercept at participant level. Challenge, period and sequence were modelled as fixed effects. Since we found no significant effect of sequence for any of the outcome variables, sequence was removed from the models. Baseline values were added as covariates. Day was included in the analysis of VAS symptom scores. We tested for interaction between challenge and period, and when significant, effect of challenge was analysed by linear mixed 
model within each period. One-way analysis of variance was used for variables with skewed distribution where data was $\ln$ transformed before analysis.

\subsection{Ethics}

All four studies were performed in accordance with the Helsinki Declaration. The clinical trials in papers I, III and IV were approved by the Regional Committee for Medical Research Ethics (REK Sout/East) and registered at http://clinicaltrials.gov, with trial identifications NCT01100099 and NCT02464150, respectively).

The study of paper II was approved by the local Privacy Commissioner for Research at Oslo University Hospital, Division for patient security and quality with the project identification number 2014/16821. Signed informed consents were obtained from all subjects.

The manuscripts of papers I and III were prepared to the best of the investigators' ability, paper II according to the standard criteria in the Strengthening the Reporting of Observational Studies in Epidemiology (STROBE) statement (http://www.strobe-statement.org) and paper IV according to the standard criteria in the Consolidated Standards of Reporting Trials (CONSORT) statement (http://www.consort-statement.org). 


\section{RESUlts}

\section{Paper I}

Twenty-three subjects with biopsy verified coeliac disease on a gluten-free diet and 34 HLA-DQ2+ NCGS subjects on a self-instituted gluten-free diet were investigated. The groups were comparable although women were slightly more frequent among the NCGS subjects than among coeliac disease subjects, 30 of 34 , and 16 of 23 , respectively ( $\mathrm{p}=0.08)$.

Diet adherence in NCGS subjects was fair to good and did not differ significantly from adherence in subjects with coeliac disease ( $83 \%$ vs $68 \%, \mathrm{p}=0.21$ ). NCGS subjects were mainly self-educated in gluten-free diet compared to coeliac disease subjects ( $91 \%$ and $39 \%$, respectively, $\mathrm{p}<0.001$ ). The gluten level varied thirteen-fold (14 000-181 $400 \mathrm{mg} / \mathrm{kg}$ ) in samples from 10 different brands of regular white bread $(n=11)$. In non-adherent subjects, there was no significant difference in gluten exposure between coeliac disease and NCGS (10 vs $138 \mathrm{mg} /$ day, p=0.83). Finally, there was no significant difference in under-reporting between coeliac disease and NCGS subjects (BMR factor 1.23 vs 1.32 , respectively, $\mathrm{p}=0.87$ ), or between adherent and non-adherent subjects (BMR factor 1.26 vs 1.36 , respectively, $\mathrm{p}=0.93$ ).

\section{Paper II}

Fifty-six patients (44 women) self-instituted on gluten-free diet for a median (IQR) of 16 months (4, 37) with mean (SD) age 41 years (15.4) and median (IQR) BMI $22.6 \mathrm{~kg} / \mathrm{m}^{2}(20,27)$ were studied. The examination of NCGS by an open bread challenge resulted in 47 patients ( $85 \%$ ) diagnosed as NCGS and nine non-NCGS. No significant differences were found between NCGS and non-NCGS as regards sex, BMI and duration of gluten-free diet $(0.50 \leq \mathrm{p} \leq 0.95)$, but the non-NCGS patients were significantly older than the NCGS patients (means 54 and 38 years, respectively, $\mathrm{p}=0.005$ ).

Total GSRS-IBS score and overall symptoms by VAS increased significantly during wheat challenge in NCGS $(\mathrm{p}<0.001)$, but not in non-NCGS subjects ( $\mathrm{p}=0.12$ and $\mathrm{p}=0.08$, respectively). Total GSRSIBS challenge score and overall symptoms by VAS were significantly higher in NCGS than in nonNCGS subjects ( 53 vs $37, \mathrm{p}=0.004$ and 76 vs $39 \mathrm{~mm}, \mathrm{p}=0.02$, respectively).

Applying the Salerno and Monash cut-offs, 35 (63\%) and 42 (75\%) would be classified with NCGS, respectively. According to total GSRS-IBS absolute agreement was lowest between clinician's diagnosis and Salerno cut-off (63 \%) and highest between Salerno and Monash cut-offs (88 \%). Further, there was higher positive than negative agreement in all comparisons. Lowest specific 
agreement was found between clinician's diagnosis and Salerno classification $\left(\mathrm{P}_{\mathrm{pos}}=83 \%, \mathrm{P}_{\text {neg }}=53 \%\right)$ and highest between Salerno and Monash classification $\left(\mathrm{P}_{\mathrm{pos}}=91 \%, \mathrm{P}_{\text {neg }}=80 \%\right)$.

\section{Paper III}

Twenty subjects (16 women), with mean (SD) age 42 years (16.5) and mean (SD) BMI $23.8 \mathrm{~kg} / \mathrm{m}^{2}$ 169 (3.9) were included in the 14-day gluten challenge. The mean duration of gluten-free diet was 119 months, ranging from 6 to 473 months. Seventeen subjects were HLA- DQ2.5 and the remaining three were HLA-DQ8.

The average villous height to crypth depth ratio $(\mathrm{Vh} / \mathrm{Cd})$ changed significantly from 2.70 at baseline to 2.26 on day 14 of gluten challenge ( $\mathrm{p}=0.002$ ). Seven of 19 subjects had biopsy $\mathrm{Vh} / \mathrm{Cd}<2.0$ on day 14 , but two had biopsy $\mathrm{Vh} / \mathrm{Cd}<2$ already at baseline. Hence, villous blunting at the end of challenge occurred in 5 of 19 subjects, and proved the efficacy of the gluten that was also used in the NCGS challenge study. Using cut-off for clinical significant absolute change in $\mathrm{Vh} / \mathrm{Cd} \leq 0.4$ as proposed by others ${ }^{183}$, we found significant decrease from baseline to day 14 in 10 of 19 subjects. The mean IEL count increased significantly from 23.5 at baseline to 40.9 on day 14 of gluten challenge $(p<0.001)$. The frequency of HLA-DQ:gluten tetramer-binding T-cells increased by more than $100 \%$ on day 6 in 12 of 15 subjects.

Symptoms, as scored by the CSI, increased significantly $(\mathrm{p}=0.002)$ from baseline to the end of challenge from a median (IQR) score of 24 (7) to 27 (8) on a 16-80 scale. VAS scores showed significant changes in stool consistency from baseline to week $1(\mathrm{p}=0.046)$, and in flatulence from baseline to week 2 ( $\mathrm{p}=0.019)$. 


\section{Paper IV}

The 59 subjects ( 53 women) that completed all three challenges had a mean (SD) age of 44 (4) years and mean (SD) BMI of $24.4 \mathrm{~kg} / \mathrm{m}^{2}(12)$, and had been on gluten-free diet the last median (IQR) 20 months $(10,48)$. According to the Rome III criteria, 18 subjects were defined as having IBS.

There was a significant difference in mean overall GSRS-IBS between gluten, fructan and placebo challenge, mean (SD) scores were 33.1 (13.3), 38.6 (12.3) and 34.3 (13.9), respectively ( $\mathrm{p}=0.04)$. The score after fructan challenge was borderline significantly higher than after gluten challenge $(\mathrm{p}=0.05)$, and no differences were found for fructan versus placebo $(p=0.19)$ and gluten versus placebo $(p=0.99)$. No significant effect of gluten was found for any symptom, but 13 subjects had highest symptom score by overall GSRS-IBS after gluten challenge.

The fructan challenge induced consistently highest scores in all GSRS-IBS dimensions, but the difference was significant only for bloating where mean (SD) scores for gluten, fructan and placebo were 9.3 (3.5), 11.6 (3.5) and 10.1 (3.7), respectively ( $\mathrm{p}=0.004)$. The fructan GSRS-IBS bloating response was significantly higher than after gluten challenge $(\mathrm{p}=0.003)$, but not higher than after placebo challenge $(\mathrm{p}=0.07)$. There was no significant difference in GSRS-IBS bloating between gluten and placebo challenge $(\mathrm{p}=0.84)$.

Daily overall gastrointestinal symptoms by VAS was highest after fructan challenge in period two, but the difference between the challenges was not significant in either of the periods.

There was a significant difference in SF-36 vitality scale scores between gluten, fructan and placebo challenge, mean (SD) 44.3 (25.2), 38.2 (23.4) and 44.4 (24.3), respectively ( $\mathrm{p}=0.04)$. The GBB dimension weakness were significantly different between gluten, fructan and placebo challenge, 32.8 (30.0), 42.5 (26.6) and 33.5 (29.7), respectively ( $p=0.02$ ). In the pairwise comparisons we found that the vitality score was significantly lower and weakness significantly higher after fructan challenge than after gluten challenge ( $p=0.04$ and $p=0.02$, respectively). No significant differences were found in fructan versus placebo or gluten versus placebo for the two variables $(0.11 \leq \mathrm{p} \leq 1.0)$. Thirteen participants had the highest overall GSRS-IBS score after consuming gluten, 24 had the highest score after consuming fructan, and 22 had the highest score after consuming placebo. No significant differences were found for the other SF-36 scales and measures for fatigue, or for other extra intestinal symptoms $(0.10 \leq \mathrm{p} \leq 0.96)$. 


\section{Discussion}

First, we found that adherence to the gluten-free diet did not differ significantly between coeliac and NCGS subjects. Second, we found that an open wheat challenge with non-standardised symptom evaluation resulted in $85 \%$ diagnosed with NCGS, higher than suggested standards. Third, diagnostic markers changed significantly in coeliac disease subjects after a 14-day gluten challenge. Finally, selfreported gluten sensitive subjects without coeliac disease recorded significantly higher overall gastrointestinal symptoms after fructan challenge compared to gluten. No significant effect of the gluten challenge was found.

\subsection{Methodological considerations}

\subsubsection{Study samples}

The subjects were recruited in the period 2009-2016 which covers the years were the public awareness and scientific research of NCGS increased substantially. There was a great willingness to contribute to research in this group, probably since many had experienced distrust and insufficient follow-up by the health care system. In the RCT of paper IV with the most comprehensive intervention, the drop-out rate was only $6 \%$. Practical and economic constraints restricted the recruitment to the southern east of Norway in all the studies. All the studies were carried out at the Oslo University Hospital, Rikshospitalet, one of very few sites that have offered a diagnostic workup for these patients.

Inclusion criteria for the self-reported gluten sensitive subjects in paper I were not as strict as the criteria in papers II and IV, in that they were not properly investigated for coeliac disease. Moreover, the subjects of paper II were exclusively referred patients, in contrast to subjects of papers I, III and IV which had a mix of referred patients and responders to public advertisements. Thus, both time span, selection and referral bias may have influenced the composition of the study samples. However, comparing the characteristics of the sample in papers I, II and IV in terms of gender, age and diet adherence, the samples appeared to be similar.

The subjects of the Paper IV study were recruited in accordance to strict inclusion criteria over a short period of time. Heterogeneity is a common characteristic of the NCGS population ${ }^{141}$, but must also be considered as possible disturbance in interpretation of the results. We abstained from baseline interventions of the study sample in order to make the subjects present as close to a clinical setting as possible. However, in regards to gender, thyroid disease, IBS and coeliac disease in close family our sample was very much alike the samples described in other challenge and cross-sectional studies ${ }^{119}$, $121,122,140,184,185$. Further, we did not find any effect of any of these factors on the challenge outcome. 
Regarding adequate exclusion of coeliac disease and coeliac disease serology, our sample was more homogenous than in previous challenge studies ${ }^{119,184}$.

\subsubsection{Study design}

A cross-sectional design was applied for the studies of papers I-II in order to compare groups retrospectively. The design in the paper III-study was an uncontrolled intervention. Controlled studies have far greater validity than uncontrolled interventions. However, the two-week gluten challenge of coeliac disease subjects aimed to assess change from baseline and was designed to validate the use of two-week gluten challenge in the diagnostic setting ${ }^{72}$.

\section{Crossover design}

The crossover design of paper IV was chosen to enable blinding of the dietary interventions. The design is rigorous and therefore has several advantages. First, the influence of confounding covariates was reduced because the subjects served as their own control. Second, the crossover design was statistically efficient and allowed fewer subjects than a parallel study ${ }^{186,187}$. The crossover design is particularly suitable for IBS or NCGS, chronic and stable diseases where the treatment intend to alleviate the disease condition, not cure it. A common disadvantage with the crossover design is the carryover effect that can bias the interpretation of the result ${ }^{188}$. Carryover effects are difficult to measure and should not be ignored. Washout periods in between each challenge intend to diminish the impact of the carryover effect. Our washout periods seemed to be of sufficient length, since symptom scores did not differ from baseline, indicating that there were minimal symptoms to carry over to the next challenge.

A crossover design should be uniform across sequence (ABC-CBA) and periods (challenge week 1-3). Then, there would be no effect of sequence or period biasing the effect of challenge. However, we observed an effect of period on the gastrointestinal symptom scores by VAS. It indicated that the effect of challenge was not the same across the periods. The placebo scores were highest in period 1 and the fructan scores were highest in period 2. Although the washout appeared to be long enough, we speculate whether a prolonged washout of at least two weeks could diminish the effect of period. Further, one week of single blinded placebo challenge prior to the challenge could possibly alleviate the expectations prior to the first period. However, the period effect is almost impossible to overcome completely because of increased subject comfort and knowledge in later periods, and improvement in skill and technique of the study team members. 


\section{Background diet}

The subjects' background diet may influence the endpoints; however, to control the background diet during a dietary intervention is a tricky exercise ${ }^{186}$. One study has succeeded in doing this.

Biesiekierski et al. succeeded in providing all food to the subjects in the crossover challenge in IBS patients ${ }^{119}$. It requires enormous effort from the investigators and reduces the self-determination of the subjects. However, the effort reduces background noise and yields high quality results. A limitation with our challenge study was that we did not control the background diet. We had two reasons for not doing it. First, we aimed to design the study as close to the clinical setting and real life as possible. Second, we wanted to spare participant burden and investigation resources. To overcome that we did not provide the background diet, we instructed the subjects to record their diet for 7 days before they entered the interventions to assess diet adherence, and told them not to change their habitual diet during the challenge periods. However, compliance was not checked during the study, and changes in the background diet could therefore not be excluded.

\subsubsection{Dietary assessment}

The 3-day weighed food record (paper I) and the 7-day food diary record (paper IV) were both prospective and open ended surveys which allowed abundant information to be collected independently of the subjects' memory. However, both methods require a high level of motivation and a relatively large burden is passed onto the respondents ${ }^{189}$. Moreover, some subjects may improve their dietary habits unintentionally through self-reflection. Some subjects may also change their diet intentionally to avoid burden on response, choose not to report actual intake or even drop out ${ }^{189}$. These limitations may result in under reporting of dietary intake. Knowing that gluten-free diet was an inclusion criterion for participation may have resulted in underreporting of gluten-containing food. However, the motivation a genuine interest in participating in research and own follow-up is believed to result in an honest contribution. Factors such as seasonal variations, illness fluctuations and travelling may always influence dietary assessment. The open ended dietary assessment methods entail a considerable effort from the investigators in terms of data collection, entry an analysis. However, an important reason why we chose the open ended methods was that assessment of glutenfree diet requires manually calculation of gluten-free foods that are not included in the Norwegian Food Composition Table. The validated, pre-coded food frequency questionnaires developed for the Norwegian adult population were unsuited for a population on gluten-free diet.

The purpose of calculating gluten exposure in paper I required a detailed description of the diet. This was achieved by choosing the weighed food record. A weakness, however, is the short time period which limits the generalization of the results. The purpose of the dietary assessment in the RCT in 
addition to evaluate diet adherence, was to describe the gluten-free diet in NCGS in general for future publications. That required a longer period of time, and therefore a 7-day food record was suitable.

\subsubsection{Gluten-free diet adherence}

Gluten-free diet is the only available treatment for coeliac disease, and follow-up of coeliac patients includes evaluation of diet adherence, especially in cases with persisting symptoms or delayed mucosal healing. Despite the clear need of a standardised instrument, validation of a test to measure gluten-free diet adherence has been difficult. Studies of conventional serologic tests have not yielded favourable results ${ }^{190-192}$. Several approaches of variable reliability are available; patient selfassessment, dietary assessment, serological and histological testing. However, the current gold standard is still considered to be evaluation by an expert dietitian with extensive experience in dietary education and follow-up of new and treated coeliac patients ${ }^{193}$. Where there are no objective biomarkers to monitor, such as in NCGS, adherence can only be evaluated by dietary assessment or by a dietitian. Further, the importance of dietary strictness may be different between NCGS and coeliac disease.

With the exception of the study of paper II, gluten-free diet adherence was determined by a multilevel assessment to ensure a result as reliable as possible. In paper I where the purpose was to compare adherence between groups we used patients' self-assessment and dietary assessment by weighed food record. These methods were supportive to the dietitian administered questionnaire considering diet understanding, diet practice and risk behaviour. The assessment of gluten-free diet of the study in paper II was exclusively based on the dietitian's dietary interview and the patients' self-assessment, since the purpose was to ensure that the patients were on a gluten-free diet. We used the multilevel approach in the RCT of paper IV to ensure that the study subjects were strictly adherent. Here, the dietitian questionnaire was improved by including information from focus groups of coeliac adults and by using background information from Leffler's CDAT ${ }^{170,193-196}$. This questionnaire was selfadministered and recorded in presence of the dietitian at the first study visit. Good adherence was required for participation, but single accidental transgressions the last six months such as having had a meal on a vacation or been served a meal at friends with unintended content of gluten were accepted.

Both Biagi et al. and Leffler et el. have developed standardised questionnaires for assessment of adherence ${ }^{170,197}$. We chose not to use these tools since they were aimed to measure the gluten-free diet adherence in coeliac disease and the level of adherence in the gluten-free diet in NCGS may not need to be as strict as in coeliac disease. Further, there was no reference method to use, since diet adherence in NCGS had not been described before. Although the dietitian assessment is regarded as gold standard, a limitation is the lack of standardisation that hampers comparison with future studies. 


\subsubsection{Gluten challenges}

\section{Open challenge}

When the National Administration of Labour and Welfare decided that reimbursement for gluten-free diet was applicable for individuals with gluten sensitivity without coeliac disease, a standardised challenge and confirmation by a gastroenterologist was required. To meet this requirement an open bread challenge with a standardised symptom recording was developed at Oslo University Hospital, Rikshospitalet in 2009. The fundamental attitude from the clinicians was that the patients were always right. Patients were not contradicted in their experience of having adverse reactions to wheat, bread or cereals or when they perceived gluten sensitivity. There were good reasons for choosing an open challenge to manage these patients: the wheat challenge mimicked the real life setting, it was a method close to how other food intolerances are managed and easy for both patient and clinician to administer. The method was accepted by the Norwegian Labour and Welfare Service and worked for the purpose of getting reimbursement for expenses related to gluten-free diet, and of the patient having a diagnosis. However, the method has limitations for the purpose of defining NCGS in the individual. The open challenge is known to overestimate positive outcomes caused by the nocebo effect ${ }^{5,186,198}$. Further, wheat fructans known to reduce symptoms in individuals with IBS if removed from the diet, had not been considered in this workup ${ }^{156,199}$. The coexistence of gluten and fructans in wheat does not allow distinguishing between reactions caused by gluten or fructans. The open wheat challenge procedure of Oslo University Hospital, Rikshospitalet was therefore terminated in 2015.

\section{Blinded challenge}

For conditions that manifest mainly with subjective symptoms, such as NCGS and other food intolerances, there have been strong indications and recommendations for the use of DBPCFC ${ }^{186}$, especially when it is not possible to contrast the results with objective biomarkers ${ }^{198}$. The muesli bars developed by Monash University, Australia allowed blinded intervention. Some subjects did observe minor differences in consistency and taste between the three types of muesli bars, but they were not able to differentiate gluten, fructan and placebo. Thus, the similarity was not perfect but the blinding was successful.

Although DBPCFC is considered the gold standard to define adverse reactions to food, a reappraisal of the procedure has revealed that the method has many pitfalls and is not as ideal as has been believed for a long time ${ }^{15,200,201}$. The limitations include poor standardisation, high costs, requirement of wellequipped facilities and trained personnel in addition to sensitivity and specificity issues ${ }^{198}$. In clinical trials, however, where successful blinding is possible and the aim is to prove or disprove the existence of a condition or to define the culprit of symptoms, the DBPCFC remains the preferred method ${ }^{36}$. 
However, an obstacle with the method used in NCGS patients is the large nocebo ${ }^{1}$ effect, the response to placebo ${ }^{119,184,185,202}$. In a clinical context, this phenomenon may cause false positive results. The problem arises of how to separate a nocebo response from a specific response with confidence, and to define who will benefit from a gluten-free diet. Therefore, DBPCFC is all but a gold standard for the clinical setting. The method is suggested to be supportive to diet history in investigation of adverse reactions to food ${ }^{203}$. For the long term follow-up of the individual patient with presumed NCGS in a clinical setting, standardised elimination and open challenge should be sufficient ${ }^{198}$.

The Australian muesli bars had previously not been used in any challenge. They were developed to enable successful blinding and mimic gluten-containing food. The moderate doses of gluten and low doses of fructans were chosen to resemble the clinical situation as closely as possible. The gluten was evidently biologically active as subjects with previously biopsy-proven coeliac disease who were challenged with the gluten muesli bars for 14-days developed significant changes (paper III). Further, the dose of $5.7 \mathrm{~g}$ gluten was believed to be adequate since previous studies have been able to demonstrate symptom responses on equivalent and lower amounts of gluten ${ }^{184,202}$.

\subsubsection{Patient reported outcome measures}

Patient reported outcome measures are useful for the aim of comparing means, comparing changes and "responder" proportions, especially for conditions where the clinical manifestations are highly subjective, such as in IBS and NCGS. Disease specific measures are developed for coeliac disease and IBS ${ }^{174,177,204-208}$. An outcome measure needs to be translated and validated to be a reliable measure in countries and conditions other than the original setting. Clinical experience and previous studies within our research group governed the choice of outcome measure in the present studies ${ }^{132,173,209,210 .}$ We considered our tools from clinical practice and research as more suitable and valid than other outcome measures adapted for IBS (ref), although an obvious limitation with GSRS-IBS and GBB in the present studies is the lack of validation for a Norwegian setting and for the NCGS population. However, the GSRS-IBS has been widely used in clinical investigation of coeliac disease, IBS and NCGS and was also used in Brottveit's research of coeliac disease and NCGS ${ }^{173}$. Another limitation with the GSRS-IBS is the lack of cut-off values ${ }^{177}$. However, as outcome measures in general, GSRSIBS works well for the assessment of effect of intervention and for the purpose of comparing different interventions ${ }^{211}$. Recall bias may occur when recording symptoms 7-14 days retrospectively by GSRS-IBS as in the study of papers III and IV. However, the daily scored VAS scales that have been used in similar challenge studies ${ }^{119,202}$ were consistent with the main findings of GSRS-IBS.

\footnotetext{
${ }^{1}$ A psychological phenomenon, in which the recipient perceives a deterioration in condition as response to a sham or dummy intervention, in this case the challenge.
} 


\subsection{Interpretation of results}

\subsubsection{Diet adherence in coeliac and non-coeliac patients}

Despite different case histories and motivation for dietary changes in coeliac disease and NCGS patients, we found minimal differences in the gluten-free diet between the groups. Adherence in coeliac disease patients seemed slightly, but not significantly better than in NCGS patients, so the prudent expectation that patients with coeliac disease had a stricter gluten-free diet than patients with NCGS was discarded. However, with increased sample size a small difference might have been detected. A type two error cannot be excluded.

The level of adherence to the gluten-free diet needed in NCGS has been unexplored until now. However, there is no evidence that the gluten-free diet in NCGS need to be as strict as for coeliac disease patients. In NCGS there is currently no defined mechanism of gluten as symptom trigger or known long-term consequences of gluten exposure. Thus, a level of adherence that allows acceptable symptom relief in the individual may be sufficient.

The $83 \%$ of coeliac disease patients with good adherence corresponded with existing knowledge ${ }^{212 \text {, }}$ ${ }^{213}$. However, a systematic review found that rates for adherence ranged from $42 \%$ to $91 \%$ depending on definition and method of assessment ${ }^{214}$. More recently, a study using the CDAT found that $75 \%$ of coeliac disease adults had adequate adherence to gluten-free diet (CDAT $\leq 13)^{212}$. In 2260 Dutch coeliac patients, $96 \%$ reported very stringent ( $50 \%$ ) or sufficient diet as response to one single selfreported question about diet adherence ${ }^{213}$. An Indian study found that $53 \%$ of coeliac patients had excellent or good adherence based on how patients categorised gluten-free and gluten-containing foods from a list ${ }^{215}$. The level of adherence increased to $92 \%$ with repeated counselling, which highlights the importance of professional diet education. If the $39 \%$ of coeliac patients that were selftaught in paper I had been professionally educated, the proportion of patients with good adherence may have increased.

Transgression did occur in both coeliac disease and NCGS patients, mostly by intake of regular beer, bread or pizza. Considered the finding of two times the expected level of gluten in regular bread, serious consequences in coeliac disease by repeated intended intake of regular bread cannot be excluded. The findings indicated that the grade of adherence is not automatically stricter in coeliac than in NCGS individuals. 


\subsubsection{Clinical workup of NCGS}

\section{Open wheat challenge in clinical practice}

The open wheat challenge is an example of how the health care system (Oslo University Hospital, Rikshospitalet) dealt with a new type of patients to the best of its ability. In the sum up of the clinical material of 2009-2015 we found a high internal consistency in that the highest symptom scores during challenge was found in the patients that were diagnosed with NCGS and lowest in non-NCGS.

Overall, this finding confirmed that the investigation succeeded in classifying correctly as regarded the symptoms. The $85 \%$ prevalence of NCGS diagnosis was not surprising because of the highly selected patient material.

However, the result must be interpreted cautiously because of the methodological limitations of the open challenge ${ }^{3}$. Further, the possible reimbursement may have motivated patients to seek the diagnosis.

\section{Symptom scoring}

Management of less defined conditions such as IBS and NCGS could be more straight forward in clinical practice with standardised cut-offs for symptom change. However, symptom relief and symptom increase are highly subjective definitions, and such standardisation would probably help the clinician more than the patient. It is difficult to standardise level of symptoms in conditions with subjective manifestations. In a clinical setting the most meaningful approach is to define the presence or absence of symptoms at baseline and then measure changes as response to intervention. Whether or not the change is significant or satisfactory will depend up on the individual. Thus, evaluation of symptom changes in clinical practice is possible and meaningful without cut-offs.

In the scientific context defined cut-offs facilitate the ability to describe and compare groups. In Biesiekierski et al the $20 \mathrm{~mm}$ minimum change of symptoms was set to separate between positive and negative response to gluten challenge ${ }^{119}$. In assessing pain in children $20 \mathrm{~mm}$ has been defined as "little more" and $40 \mathrm{~mm}$ as "much more" of the symptom ${ }^{216}$, and $22 \mathrm{~mm}$ has been considered as minimal clinical change for measuring nausea in adults ${ }^{175}$. The suggested minimal $30 \%$ symptom change as response to the shift from normal diet to gluten-free diet, and as response to a gluten challenge was an attempt to standardise the diagnostics of NCGS ${ }^{139}$. However, the high prevalence of placebo responses in such challenges reduces the clinical value of this standard. 


\subsubsection{Exclusion of coeliac disease}

One inclusion criterion for subjects with self-reported gluten sensitivity in the crossover gluten challenge (paper IV) was adequately exclusion of coeliac disease. Many reported that they had undergone a gastroscopy with duodenal biopsy while on gluten-containing diet. However, further elaboration revealed cases were the gluten exposure was too short and/or too low $(<4$ slices of bread in $<2$ weeks). These subjects were considered non-eligible for participation. There was a risk of false negative result for coeliac disease that could lead to an incorrect diagnosis of NCGS. Previous studies investigating NCGS may have suffered from inadequate exclusion of coeliac disease of the study subjects and therefore been biased by coeliac disease subjects ${ }^{108,217}$. A less invasive method could simplify the exclusion or confirmation of coeliac disease for those already on a gluten-free diet. However, the 14-day gluten challenge was not enough to detect coeliac disease by conventional histological evaluation of duodenal biopsies. This study supported clinical decision making in favour of longer duration of gluten challenge.

The optimal dose of gluten in a short challenge is not known and should probably be seen in conjunction with the duration of the challenge. One study of 6-week gluten challenge in adults in mucosal remission used daily doses of 1.5, 2, 3 and $6 \mathrm{~g}$ gluten, showing a clear dose response effect, diminishing towards the higher doses, as doses of 3 and $6 \mathrm{~g}$ were both able to give $\mathrm{Vh} / \mathrm{Cd} \leq 2$ in about $70 \%$ of the subjects ${ }^{218}$. It is, however, not clear when the villous blunting occurred during the 6 -week time frame. Thus, although a daily gluten dose of $3 \mathrm{~g}$ may be sufficient for a 6-week challenge, it may not be sufficient for a 14-day challenge, as seen in our study where the use of $5.7 \mathrm{~g}$ gluten daily only gave $\mathrm{Vh} / \mathrm{Cd} \leq 2$ in approximately one-third of the subjects. An alternative strategy for response evaluation could be repeated sets of duodenal biopsies, before and after gluten challenge. This approach could provide a more sensitive readout than the recommended practice of only taking one set of biopsies at the end of a gluten challenge. Applying the absolute change in $\mathrm{Vh} / \mathrm{Cd}$ of 0.4 and an IEL change of about $50 \%$ in H\&E-stained biopsies, the sensitivity of the 14-day gluten challenge increased to $50 \%$ but was still found unsatisfactory ${ }^{183}$. A twofold change in gluten-specific T-cell response in blood, measured by HLA-DQ:gluten tetramers, was detected after 6 days of gluten challenge in a majority of subjects with coeliac disease in remission. This approach could be applied to detect coeliac disease after a short gluten challenge. The method is promising but needs further evaluation.

\subsubsection{Symptom inducers in NCGS}

Previous and recent publications and editorials have questioned the role of gluten as symptom trigger in people without coeliac disease and discussed the ambiguous overlap between IBS and NCGS, but with a restricted number of good clinical trials ${ }^{39,118,133,155,219-221}$. It is beyond controversy that intake 
of wheat, rye and barley can induce symptoms in individuals without coeliac disease ${ }^{222}$. Further, there are sources of evidence that some individuals may benefit from a gluten-free diet without having coeliac disease. However, not all effects of a gluten-free diet are due to the removal of gluten. Randomised double-blind placebo-controlled gluten challenges have shown that gluten induce more symptoms than placebo in subjects that self-report gluten sensitivity ${ }^{107,109}$. However, double-blind crossover re-challenge studies have failed to identify specificity of gluten in inducing symptoms in all but possibly a minority $(<10 \%)$ of patients with self-reported NCGS ${ }^{217}$. Further, there are no defined predictors of response to a gluten-free diet. Large placebo responses in challenge studies demonstrate how difficult it is to define who will benefit from a gluten-free $\operatorname{diet}^{119,184,185,202}$. Further, alteration of the gluten content of the diet has effects on dietary constituents in addition to gluten such as the fructans. Consequently, research has gradually looked beyond gluten to search for the real culprit and meanwhile suggested that non-coeliac wheat sensitivity is a more correct name ${ }^{141,220,223}$.

The present crossover challenge is the first randomised clinical trial to study the effect of fructans (without gluten) in individuals with self-reported NCGS. The most certain finding was the lack of difference between gluten and placebo responses. This finding alone weakens the role of gluten in NCGS. The gluten dose was certainly moderate $(5.7 \mathrm{~g})$. Nevertheless, lower doses have shown to induce symptoms in other challenge studies of suspected NCGS individuals ${ }^{184,202}$. Several blinded, crossover studies have claimed in their conclusions that the presence of NCGS is unequivocally present in a proportion of patients believing they are gluten sensitive, and strong recommendations that gluten-free diet should be used in patients with IBS have been made on the basis of such data. In these studies, patients with greater gluten response have been labelled as having NCGS. For instance, in the study by Zanini et al., patients were asked to identify which of the rechallenged substance was gluten, based upon their symptoms ${ }^{185}$. One-third identified gluten and the authors then defined that subgroup as having NCGS. The same interpretation was applied in the study of Elli et al. ${ }^{202}$. Di Sabatino also found that gluten induced significantly more symptoms than placebo. However, only three subjects could be defined as having a gluten specific response when a statistical approach such as two standard deviations was applied ${ }^{184}$.

The fructans induced significantly higher symptom score for overall GSRS-IBS and several subdimensions. The response to fructans strengthen the hypothesis that wheat fructans are the real symptom inducer rather than gluten. This picture fits well with the mechanistic effect of FODMAP on gastrointestinal symptoms which is already well studied and understood ${ }^{136,162,199,224}$. The fact that the responses were not huge in magnitude is not unexpected as, in the context of usual food, cereal-based fructans will be ingested in association with other indigestible oligosaccharides as well as other FODMAP. 
Originally, the fructan content of the muesli bar was not decided with the purpose of triggering symptoms, but to mimic the content of fructans in four slices of white wheat bread $(2.1 \mathrm{~g})$.

Consequently, the fructan challenge almost doubled their habitual daily fructan exposure of $2.2 \mathrm{~g} /$ day. The amount is sufficient to cause symptoms ${ }^{98}$. However, the amount was still lower than the $5 \mathrm{~g}$ that did not induce gastrointestinal symptoms in healthy adults in the study of Erickson et al $2017^{225}$.

In addition to increase in the overall GSRS-IBS, the effect on GSRS bloating fitted well with the significant improvement of bloating as a response to low FODMAP diet reduction in IBS patients ${ }^{156}$. Likewise, the lack of fructan effect on bowel habits supported the lack of effect on appearances and fecal water content in a feeding intervention ${ }^{226}$.

The effect of the fructan challenge was not restricted to abdominal symptoms. The SF-36 vitality scale was significantly lower and VAS weakness significantly increased as response to the fructan challenge compared to gluten and placebo. Improvement in quality of life in IBS patients has been found as an effect of low FODMAP diet ${ }^{106}$. Whether improvement in vitality and weakness are directly related to fructan exposure or secondary to the higher degree of gastrointestinal symptoms cannot be ascertained.

Wheat-generated symptoms may depend on combined exposure to gluten and fructans with synergistic actions. This combination was not studied here. It is also possible that fructans present naturally in the food matrix behaves differently to supplements of pure fructo-oligosaccharides added to the diet. Further, the fructo-oligosaccharide added in the muesli bars originated from chicory roots and might have different effect from the fructo-oligosaccharide in wheat. Other components of wheat, such as the ATIs and the lectin, wheat germ agglutinin, were not considered in the current study apart from not being able to detect the ATIs ${ }^{45}$. In vitro studies have found effect on cell activation of these components ${ }^{45,227}$, but in IBS and NCGS patients the pathogenic role of ATIs and wheat germ agglutinin is unexplored.

The results of the current study weakens the role of gluten as a symptom inducer in patients with selfreported NCGS, supported the report by Biesiekierski et al. in a blinded re-challenge study where the subjects were receiving a low FODMAP diet with tight control of background confounders ${ }^{119}$. In the initial run-in to the blinded re-challenges, Biesiekierski et al. taught the subjects how to minimize FODMAP in their diets, and this caused a uniform reduction of symptoms. This may have been a placebo effect, but the findings of the present study support that it was a specific effect of the reduction of total FODMAP. Biesiekierski et al. was not able to find any specific or dose dependent (3 and $16 \mathrm{~g}$ ) effect of gluten in their randomised double-blind placebo-controlled challenge study. 


\subsubsection{Implications}

Norway has been one of few countries that have provided governmental reimbursement for patients with NCGS, equivalent to what patients with coeliac disease receive. In the light of the present findings, this reimbursement may need reconsidering or implementation of more rigorous requirements. Clinicians may need to have focus on lowering dietary FODMAP before removing gluten from the patient's diet. Overall, self-reported gluten-sensitivity without coeliac disease should be managed as IBS rather than an independent entity.

\subsection{Limitations}

An important limitation of the comparisons between coeliac disease and NCGS in paper I was the small number of subjects in each group, which influenced the number of diet recordings, the variety and number of analysed foods and the number of gluten-consuming subjects. For this reason type two errors cannot be excluded.

The number of NCGS subjects may have been overestimated in papers I-II due to the open bread challenge, which is known to create false positive results. Further, the challenge vehicle included several possible symptom-inducing components, and the symptom change was not evaluated in accordance to a standard.

A methodological weakness of the study in papers II-IV was the lack of validation of several of the patient reported outcomes measures. Despite long experience with the methods in clinic and research, the results must be interpreted with some modesty.

A possible limitation in generalizing from the findings of the 14-day challenge in coeliac disease patients of paper III was the low number of subjects. Further, coeliac disease patients who had a history of strong gluten-related symptoms were excluded to ensure that the subjects were able to complete the 14-day challenge and that evaluation of morphological response was possible.

Limitations of the randomised double-blind placebo-controlled challenge in Paper IV included no control of the background diet and no dietary assessment during the challenge to ensure that the subjects adhered strictly to the habitual gluten-free diet. Changes in the background diet with possible implications for the symptoms were not controlled. Muesli bars as challenge vehicle has to our knowledge not been used in gluten challenges before. Gluten was proved biologically active, however, the source of fructooligosaccharide was not tested. Further, the effect of time that appeared as a significant period by challenge interaction for the symptoms measured by VAS, was probably an effect of the subjects' expectation of distress, which is difficult to overcome in crossover studies. It 
entailed different challenge effect between periods, which is not ideal in a crossover design. Repeated active and placebo challenges may overcome such period effect. Although there was no difference between baseline and washout symptoms, the period effect could have been reduced with increased length of the washout periods. Finally, the study did not include the combination of gluten and fructans together as a separate challenge arm. The possibility of a synergistic effect of the combined components cannot be ignored.

\subsection{Future perspectives}

Exploring the nature of gluten-free diet whether it is subjects with or without coeliac disease is of importance since it excludes bread and cereals as the most important staple food of the Western diet. Future studies should explore the nutrient composition of gluten-free diet applied by non-coeliac subjects.

Our findings propose that cereals are the most frequent source of gluten in transgressions of glutenfree diet. The results also indicate lack of standardised recipes regarding vital gluten as bread ingredient even within the same brand. Consequently, gluten challenge by a certain number of slices of white bread may give highly variable gluten loads. Whether the aim is to estimate gluten exposure as a cause of diet transgression or to standardise a gluten challenge in coeliac disease wok-up, it requires extended knowledge about gluten content of wheat flour and the amount of purified vital gluten added in bread and cereals during production.

The current guidelines for coeliac disease workup for subjects already on a gluten-free diet may be an obstacle of obtaining a correct diagnosis. A less invasive workup that is based on a short-duration gluten challenge, followed by blood test based on HLA-DQ:gluten tetramers as biomarker is promising but should be explored further.

Finding the alternative food component that is responsible for symptom induction in self-reported NCGS is important as it provides guidance on likely more efficacious and less restrictive dietary approach to giving symptomatic relief to the patients. The clinical challenge is how to define those few patients with specific gluten response. One clinical approach is to reintroduce a gluten-containing, low FODMAP food, such as sourdough spelt bread, after an elimination phase of the low FODMAP diet. However, even with clinical relevant symptom response to such a reintroduction, open or blinded, the gluten specificity of the symptoms would not be certain. Further aspects are suggested for future research:

- The fructan effect and lack of gluten response as well as the efficacy of muesli bars as challenge vehicle need to be replicated to prove the validity of the current findings. 
- The effect of a low FODMAP diet should be further explored in the group of self-reported NCGS on self-instituted gluten-free diet.

- Mechanistic research in subjects with self-reported NCGS needs to focus beyond gluten.

- Studies designed to measure extra-intestinal symptoms as primary outcome are needed to explore effects beyond the gastrointestinal symptoms.

- The possibility of a synergistic effect of gluten and fructan in combination should be explored.

- The effect of gluten removal and reduction of fructans in the diet should be compared in an "all food provided"-setting. 


\section{CONCLUSIONS}

Gluten-free diet adherence did not differ between coeliac disease and NCGS subjects. Diet adherence was fair to good in NCGS even though most of them were self-educated in gluten-free diet. Gluten content of bread differed greatly and certain brands contained more than two times the expected gluten level.

Open wheat challenges in clinical follow-up of patients with presumed NCGS from 2009 to 2015 resulted in $85 \%$ diagnosed as NCGS. Subjects diagnosed with NCGS reported significantly more gastrointestinal symptoms than non-NCGS subjects. An overestimation in the clinician's diagnosis was probable since the prevalence was lower according to both the Salerno and Monash cut-offs classifications. Best agreement was found between the Salerno and Monash cut-offs, and lowest between clinician's diagnosis and Salerno cut-off.

A 14-day gluten challenge was inadequate when villous blunting or increased coeliac disease specific antibody levels were used as outcome measures. Repeated biopsies taken before and after a short gluten challenge can increase the sensitivity of the test, but not enough to recommend this procedure. Longer duration challenge is required. Increase in CD4+ effector-memory gut-homing HLADQ:gluten tetramer-binding T cells in blood six days after gluten challenge was a more sensitive and less invasive biomarker that should be explored further.

The randomised, double-blind placebo-controlled crossover challenge study in subjects with selfreported NCGS showed that fructans emerge as a culprit without any evidence to implicate gluten. In other words, 'self-reported NCGS' is in the vast majority not 'NCGS', but rather likely to be a doserelated effect of fructans. The finding weakens the use of the term "NCGS" and raises doubts about the need for a gluten-free diet in such patients. 


\section{REFERENCES}

1. Zopf Y, Baenkler HW, Silbermann A, et al. The differential diagnosis of food intolerance. Dtsch Arztebl Int 2009;106:359-69; quiz 369-70; 4 p following 370.

2. Sicherer SH, Sampson HA. 9. Food allergy. Journal of Allergy and Clinical Immunology 2006;117:S470-S475.

3. Bindslev-Jensen C, Ballmer-Weber BK, Bengtsson U, et al. Standardization of food challenges in patients with immediate reactions to foods--position paper from the European Academy of Allergology and Clinical Immunology. Allergy 2004;59:690-7.

4. Pereira B, Venter C, Grundy J, et al. Prevalence of sensitization to food allergens, reported adverse reaction to foods, food avoidance, and food hypersensitivity among teenagers. $\mathrm{J}$ Allergy Clin Immunol 2005;116:884-92.

5. Venter C, Pereira B, Grundy J, et al. Incidence of parentally reported and clinically diagnosed food hypersensitivity in the first year of life. J Allergy Clin Immunol 2006;117:1118-24.

6. Bohn L, Storsrud S, Tornblom H, et al. Self-reported food-related gastrointestinal symptoms in IBS are common and associated with more severe symptoms and reduced quality of life. Am J Gastroenterol 2013;108:634-41.

7. Monsbakken KW, Vandvik PO, Farup PG. Perceived food intolerance in subjects with irritable bowel syndrome-- etiology, prevalence and consequences. Eur J Clin Nutr 2006;60:667-72.

8. Hayes PA, Fraher MH, Quigley EM. Irritable bowel syndrome: the role of food in pathogenesis and management. Gastroenterol Hepatol (N Y) 2014;10:164-74.

9. Johansson SGO, Bieber T, Dahl R, et al. Revised nomenclature for allergy for global use: Report of the Nomenclature Review Committee of the World Allergy Organization, October 2003. Journal of Allergy and Clinical Immunology 2004;113:832-836.

10. Levin ME, Gray CL, Goddard E, et al. South African food allergy consensus document 2014. S Afr Med J 2015;105:62-5.

11. Bruijnzeel-Koomen C, Ortolani C, Aas K, et al. Adverse reactions to food. European Academy of Allergology and Clinical Immunology Subcommittee. Allergy 1995;50:623-35.

12. Staudacher HM, Irving PM, Lomer MC, et al. Mechanisms and efficacy of dietary FODMAP restriction in IBS. Nat Rev Gastroenterol Hepatol 2014;11:256-66.

13. McKenzie YA, Alder A, Anderson W, et al. British Dietetic Association evidence-based guidelines for the dietary management of irritable bowel syndrome in adults. J Hum Nutr Diet 2012;25:260-74.

14. Skypala I. Adverse food reactions--an emerging issue for adults. J Am Diet Assoc 2011;111:1877-91.

15. Niggemann B, Beyer K. Pitfalls in double-blind, placebo-controlled oral food challenges. Allergy 2007;62:729-32.

16. Leung J, Crowe SE. Food allergy and food intolerance. World Rev Nutr Diet 2015;111:76-81.

17. Inomata N. Wheat allergy. Curr Opin Allergy Clin Immunol 2009;9:238-43.

18. Rubio-Tapia A, Hill ID, Kelly CP, et al. ACG clinical guidelines: diagnosis and management of celiac disease. Am J Gastroenterol 2013;108:656-76; quiz 677.

19. Beaudouin E, Renaudin JM, Morisset M, et al. Food-dependent exercise-induced anaphylaxis-update and current data. Eur Ann Allergy Clin Immunol 2006;38:45-51.

20. Sollid LM, Lundin KE. Diagnosis and treatment of celiac disease. Mucosal Immunol 2009;2:3-7.

21. Lundin KE, Qiao SW, Snir O, et al. Coeliac disease - from genetic and immunological studies to clinical applications. Scand J Gastroenterol 2015;50:708-17.

22. Ludvigsson JF, Leffler DA, Bai JC, et al. The Oslo definitions for coeliac disease and related terms. Gut 2013;62:43-52. 
23. DiGiacomo DV, Tennyson CA, Green PH, et al. Prevalence of gluten-free diet adherence among individuals without celiac disease in the USA: results from the Continuous National Health and Nutrition Examination Survey 2009-2010. Scand J Gastroenterol 2013;48:921-5.

24. Golley S, Corsini N, Topping D, et al. Motivations for avoiding wheat consumption in Australia: results from a population survey. Public Health Nutr 2015;18:490-9.

25. Sanders DS, Carter MJ, Hurlstone DP, et al. Association of adult coeliac disease with irritable bowel syndrome: a case-control study in patients fulfilling ROME II criteria referred to secondary care. Lancet 2001;358:1504-8.

26. Hauser W, Musial F, Caspary WF, et al. Predictors of irritable bowel-type symptoms and healthcare-seeking behavior among adults with celiac disease. Psychosom Med 2007;69:3706.

27. Sainsbury A, Sanders DS, Ford AC. Prevalence of irritable bowel syndrome-type symptoms in patients with celiac disease: a meta-analysis. Clin Gastroenterol Hepatol 2013;11:359-65.e1.

28. Aziz I, Branchi F, Pearson K, et al. A Study Evaluating the Bidirectional Relationship Between Inflammatory Bowel Disease and Self-reported Non-celiac Gluten Sensitivity. Inflamm Bowel Dis 2015;21:847-53.

29. Aziz I, Sanders DS. The irritable bowel syndrome-celiac disease connection. Gastrointest Endosc Clin N Am 2012;22:623-37.

30. Spiller R, Aziz Q, Creed F, et al. Guidelines on the irritable bowel syndrome: mechanisms and practical management. Gut 2007;56:1770-98.

31. Catassi C, Alaedini A, Bojarski C, et al. The Overlapping Area of Non-Celiac Gluten Sensitivity (NCGS) and Wheat-Sensitive Irritable Bowel Syndrome (IBS): An Update. Nutrients 2017;9(11). pii: E1268. doi: 10.3390/nu9111268.

32. Husby S, Murray J. Non-celiac gluten hypersensitivity: What is all the fuss about? F1000Prime Reports 2015;12;7:54. doi: 10.12703/P7-54.

33. Volta U, De Giorgio R. New understanding of gluten sensitivity. Nat Rev Gastroenterol Hepatol 2012;9:295-9(5):295-9.

34. Sapone A, Bai JC, Ciacci C, et al. Spectrum of gluten-related disorders: consensus on new nomenclature and classification. BMC Med 2012;10:13. doi: 10.1186/1741-7015-10-13

35. Catassi C, Bai J, Bonaz B, et al. Non-Celiac Gluten sensitivity: the new frontier of gluten related disorders. Nutrients 2013;5:3839-53.

36. Gibson PR, Skodje GI, Lundin KE. Non-coeliac gluten sensitivity. J Gastroenterol Hepatol 2017;32 Suppl 1:86-89.

37. Gibson PR, Muir J, Newnham ED. Other dietary confounders: FODMAPS et al. Digestive diseases 2015;33:269-276.

38. Newnham ED. Does gluten cause gastrointestinal symptoms in subjects without coeliac disease? J Gastroenterol Hepatol 2011;26 Suppl 3:132-4.

39. Biesiekierski JR, Muir JG, Gibson PR. Is gluten a cause of gastrointestinal symptoms in people without celiac disease? Curr Allergy Asthma Rep 2013;13:631-8.

40. Shewry PR. Wheat. J Exp Bot 2009;60:1537-53.

41. Schalk K, Lexhaller B, Koehler P, et al. Isolation and characterization of gluten protein types from wheat, rye, barley and oats for use as reference materials. PLoS One 2017;12:e0172819.

42. Wieser H. Chemistry of gluten proteins. Food Microbiol 2007;24:115-9.

43. Hoppe C, Gobel R, Kristensen M, et al. Intake and sources of gluten in 20- to 75-year-old Danish adults: a national dietary survey. Eur J Nutr 2017;56:107-117.

44. Pastorello EA, Farioli L, Conti A, et al. Wheat IgE-mediated food allergy in European patients: alpha-amylase inhibitors, lipid transfer proteins and low-molecular-weight glutenins. Allergenic molecules recognized by double-blind, placebo-controlled food challenge. Int Arch Allergy Immunol 2007;144:10-22.

45. Junker Y, Zeissig S, Kim SJ, et al. Wheat amylase trypsin inhibitors drive intestinal inflammation via activation of toll-like receptor 4. J Exp Med 2012;209:2395-408.

46. Schuppan D, Zevallos V. Wheat amylase trypsin inhibitors as nutritional activators of innate immunity. Dig Dis 2015;33:260-3.

47. Biesiekierski JR. What is gluten? J Gastroenterol Hepatol 2017;32 Suppl 1:78-81. 
48. Gibson P. There is more to wheat than gluten and more to NCGS than IBS, In International Coeliac Disease Symposium, Prague, Czech Republic, 21-24 June, 2015.

49. Muir JG, Shepherd SJ, Rosella O, et al. Fructan and free fructose content of common Australian vegetables and fruit. J Agric Food Chem 2007;55:6619-27.

50. Muir JG, Rose R, Rosella O, et al. Measurement of short-chain carbohydrates in common Australian vegetables and fruits by high-performance liquid chromatography (HPLC). J Agric Food Chem 2009;57:554-65.

51. Gibson GR, Roberfroid MB. Dietary modulation of the human colonic microbiota: introducing the concept of prebiotics. J Nutr 1995;125:1401-12.

52. Van Loo J, Cummings J, Delzenne N, et al. Functional food properties of non-digestible oligosaccharides: a consensus report from the ENDO project (DGXII AIRII-CT94-1095). Br J Nutr 1999;81:121-32.

53. Rumessen JJ, Gudmand-Hoyer E. Functional bowel disease: malabsorption and abdominal distress after ingestion of fructose, sorbitol, and fructose-sorbitol mixtures. Gastroenterology 1988;95:694-700.

54. De Giorgio R, Volta U, Gibson PR. Sensitivity to wheat, gluten and FODMAPs in IBS: Facts or fiction? Gut 2016;65:169-178.

55. Biesiekierski JR, Rosella O, Rose R, et al. Quantification of fructans, galacto-oligosacharides and other short-chain carbohydrates in processed grains and cereals. J Hum Nutr Diet 2011;24:154-76.

56. Whelan K, Abrahmsohn O, David GJ, et al. Fructan content of commonly consumed wheat, rye and gluten-free breads. Int J Food Sci Nutr 2011;62:498-503.

57. Kupfer SS, Jabri B. Pathophysiology of celiac disease. Gastrointest Endosc Clin N Am 2012;22:639-60.

58. Dicke WK, Weijers HA, Van De Kamer JH. Coeliac disease. II. The presence in wheat of a factor having a deleterious effect in cases of coeliac disease. Acta Paediatr 1953;42:34-42.

59. Abadie V, Sollid LM, Barreiro LB, et al. Integration of genetic and immunological insights into a model of celiac disease pathogenesis. Annu Rev Immunol 2011;29:493-525.

60. Ludvigsson JF, Bai JC, Biagi F, et al. Diagnosis and management of adult coeliac disease: guidelines from the British Society of Gastroenterology. Gut 2014;63:1210-28.

61. Dube C, Rostom A, Sy R, et al. The prevalence of celiac disease in average-risk and at-risk Western European populations: a systematic review. Gastroenterology 2005;128:S57-67.

62. Jabri B, Sollid LM. Mechanisms of disease: immunopathogenesis of celiac disease. Nat Clin Pract Gastroenterol Hepatol 2006;3:516-25.

63. Haere $\mathrm{P}$, Hoie $\mathrm{O}$, Schulz T, et al. Long-term mucosal recovery and healing in celiac disease is the rule - not the exception. Scand J Gastroenterol 2016:1-8.

64. Shan L, Molberg O, Parrot I, et al. Structural basis for gluten intolerance in celiac sprue. Science 2002;297:2275-9.

65. Lundin KE, Scott H, Fausa O, et al. T cells from the small intestinal mucosa of a DR4, DQ7/DR4, DQ8 celiac disease patient preferentially recognize gliadin when presented by DQ8. Hum Immunol 1994;41:285-91.

66. Lundin KE, Sollid LM, Bosnes V, et al. T-cell recognition of HLA class II molecules induced by gamma-interferon on a colonic adenocarcinoma cell line (HT29). Scand J Immunol 1990;31:469-75.

67. Sollid LM, Markussen G, Ek J, et al. Evidence for a primary association of celiac disease to a particular HLA-DQ alpha/beta heterodimer. J Exp Med 1989;169:345-50.

68. Sollid LM, Jabri B. Triggers and drivers of autoimmunity: lessons from coeliac disease. Nat Rev Immunol 2013;13:294-302.

69. Bouziat R, Hinterleitner R, Brown JJ, et al. Reovirus infection triggers inflammatory responses to dietary antigens and development of celiac disease. Science 2017;356:44-50.

70. Stene LC, Honeyman MC, Hoffenberg EJ, et al. Rotavirus infection frequency and risk of celiac disease autoimmunity in early childhood: a longitudinal study. Am J Gastroenterol 2006;101:2333-40. 
71. Kim HS, Patel KG, Orosz E, et al. Time Trends in the Prevalence of Celiac Disease and Gluten-Free Diet in the US Population: Results From the National Health and Nutrition Examination Surveys 2009-2014. JAMA Intern Med 2016;176:1716-1717.

72. Leffler D, Schuppan D, Pallav K, et al. Kinetics of the histological, serological and symptomatic responses to gluten challenge in adults with coeliac disease. Gut 2013;62:9961004.

73. Lahdeaho ML, Maki M, Laurila K, et al. Small- bowel mucosal changes and antibody responses after low- and moderate-dose gluten challenge in celiac disease. BMC Gastroenterol 2011;11:129.

74. Mearin F, Lacy BE, Chang L, et al. Bowel Disorders. Gastroenterology 2016.

75. Lewis SJ, Heaton KW. Stool form scale as a useful guide to intestinal transit time. Scand J Gastroenterol 1997;32:920-4.

76. Lovell RM, Ford AC. Effect of gender on prevalence of irritable bowel syndrome in the community: systematic review and meta-analysis. Am J Gastroenterol 2012;107:991-1000.

77. Agarwal N, Spiegel BM. The effect of irritable bowel syndrome on health-related quality of life and health care expenditures. Gastroenterol Clin North Am 2011;40:11-9.

78. Peery AF, Dellon ES, Lund J, et al. Burden of gastrointestinal disease in the United States: 2012 update. Gastroenterology 2012;143:1179-87.e1-3.

79. Ballou S, Keefer L. The impact of irritable bowel syndrome on daily functioning: Characterizing and understanding daily consequences of IBS. Neurogastroenterol Motil 2017;29.

80. Zuo XL, Li YQ, Shi L, et al. Visceral hypersensitivity following cold water intake in subjects with irritable bowel syndrome. J Gastroenterol 2006;41:311-7.

81. Simren M, Abrahamsson H, Bjornsson ES. An exaggerated sensory component of the gastrocolonic response in patients with irritable bowel syndrome. Gut 2001;48:20-7.

82. Portincasa P, Moschetta A, Baldassarre G, et al. Pan-enteric dysmotility, impaired quality of life and alexithymia in a large group of patients meeting ROME II criteria for irritable bowel syndrome. World J Gastroenterol 2003;9:2293-9.

83. Marshall JK, Thabane M, Borgaonkar MR, et al. Postinfectious irritable bowel syndrome after a food-borne outbreak of acute gastroenteritis attributed to a viral pathogen. Clin Gastroenterol Hepatol 2007;5:457-60.

84. Thabane M, Kottachchi DT, Marshall JK. Systematic review and meta-analysis: The incidence and prognosis of post-infectious irritable bowel syndrome. Aliment Pharmacol Ther 2007;26:535-44.

85. Staudacher HM, Whelan K. Altered gastrointestinal microbiota in irritable bowel syndrome and its modification by diet: Probiotics, prebiotics and the low FODMAP diet. Proceedings of the Nutrition Society 2016;75:306-318.

86. Simren M, Barbara G, Flint HJ, et al. Intestinal microbiota in functional bowel disorders: a Rome foundation report. Gut 2013;62:159-76.

87. Ford AC, Spiegel BM, Talley NJ, et al. Small intestinal bacterial overgrowth in irritable bowel syndrome: systematic review and meta-analysis. Clin Gastroenterol Hepatol 2009;7:1279-86.

88. Chang L. The role of stress on physiologic responses and clinical symptoms in irritable bowel syndrome. Gastroenterology 2011;140:761-5.

89. Litleskare S, Wensaas KA, Eide GE, et al. Perceived food intolerance and irritable bowel syndrome in a population 3 years after a giardiasis-outbreak: A historical cohort study. BMC Gastroenterology 2015;15 (1) (no pagination).

90. Simren M, Mansson A, Langkilde AM, et al. Food-related gastrointestinal symptoms in the irritable bowel syndrome. Digestion 2001;63:108-15.

91. Guo H, Jiang T, Wang J, et al. The value of eliminating foods according to food-specific immunoglobulin $\mathrm{G}$ antibodies in irritable bowel syndrome with diarrhoea. J Int Med Res 2012;40:204-10.

92. Drisko J, Bischoff B, Hall M, et al. Treating irritable bowel syndrome with a food elimination diet followed by food challenge and probiotics. J Am Coll Nutr 2006;25:514-22. 
93. Jones VA, McLaughlan P, Shorthouse M, et al. Food intolerance: a major factor in the pathogenesis of irritable bowel syndrome. Lancet 1982;2:1115-7.

94. Ong DK, Mitchell SB, Barrett JS, et al. Manipulation of dietary short chain carbohydrates alters the pattern of gas production and genesis of symptoms in irritable bowel syndrome. $\mathrm{J}$ Gastroenterol Hepatol 2010;25:1366-73.

95. Olesen M, Gudmand-Hoyer E. Efficacy, safety, and tolerability of fructooligosaccharides in the treatment of irritable bowel syndrome. Am J Clin Nutr 2000;72:1570-5.

96. Pedersen A, Sandstrom B, Van Amelsvoort JM. The effect of ingestion of inulin on blood lipids and gastrointestinal symptoms in healthy females. Br J Nutr 1997;78:215-22.

97. Clausen MR, Jorgensen J, Mortensen PB. Comparison of diarrhea induced by ingestion of fructooligosaccharide Idolax and disaccharide lactulose: role of osmolarity versus fermentation of malabsorbed carbohydrate. Dig Dis Sci 1998;43:2696-707.

98. Shepherd SJ, Parker FC, Muir JG, et al. Dietary triggers of abdominal symptoms in patients with irritable bowel syndrome: randomized placebo-controlled evidence.

Clin.Gastroenterol.Hepatol. 2008;6:765-771.

99. Tuck CJ, Taylor KM, Gibson PR, et al. Increasing Symptoms in Irritable Bowel Symptoms With Ingestion of Galacto-Oligosaccharides Are Mitigated by alpha-Galactosidase Treatment. Am J Gastroenterol 2018;113(1):124-134.

100. Longstreth GF, Thompson WG, Chey WD, et al. Functional bowel disorders. Gastroenterology 2006;130:1480-91.

101. Chen L, Ilham SJ, Feng B. Pharmacological Approach for Managing Pain in Irritable Bowel Syndrome: A Review Article. Anesth Pain Med 2017;7:e42747.

102. Peters SL, Yao CK, Philpott H, et al. Randomised clinical trial: the efficacy of gut-directed hypnotherapy is similar to that of the low FODMAP diet for the treatment of irritable bowel syndrome. Alimentary Pharmacology and Therapeutics 2016;44:447-459.

103. NICE. National Institute for Health and Clinical Excellence (NICE) Irritabel bowel syndrome in adults. Diagnosis and management of irritabel bowel syndrome in primary care, 2017. https://www.nice.org.uk/guidance/cg61. Accessed February 20, 2018.

104. Bohn. Diet Low in FODMAPs Reduces Symptoms of Irritable Bowel Syndrome as Well as Traditional Dietary Advice: A Randomized Controlled Trial. Gastroenterology 2015;149:1399-1407.e2.

105. Mazzawi T, Hausken T, Gundersen D, et al. Effects of dietary guidance on the symptoms, quality of life and habitual dietary intake of patients with irritable bowel syndrome. Mol Med Rep 2013;8:845-52.

106. Ostgaard H, Hausken T, Gundersen D, et al. Diet and effects of diet management on quality of life and symptoms in patients with irritable bowel syndrome. Mol Med Rep 2012;5:1382-90.

107. Biesiekierski JR, Newnham ED, Irving PM, et al. Gluten causes gastrointestinal symptoms in subjects without celiac disease: a double-blind randomized placebo-controlled trial. Am J Gastroenterol 2011;106:508-14; quiz 515.

108. Wahnschaffe U, Schulzke JD, Zeitz M, et al. Predictors of clinical response to gluten-free diet in patients diagnosed with diarrhea-predominant irritable bowel syndrome. Clin Gastroenterol Hepatol 2007;5:844-50; quiz 769.

109. Shahbazkhani B, Sadeghi A, Malekzadeh R, et al. Non-Celiac Gluten Sensitivity Has Narrowed the Spectrum of Irritable Bowel Syndrome: A Double-Blind Randomized PlaceboControlled Trial. Nutrients 2015;7:4542-54.

110. Vazquez-Roque MI, Camilleri M, Smyrk T, et al. A controlled trial of gluten-free diet in patients with irritable bowel syndrome-diarrhea: effects on bowel frequency and intestinal function. Gastroenterology 2013;144:903-911 e3.

111. Lundin KE, Alaedini A. Non-celiac gluten sensitivity. Gastrointest Endosc Clin N Am 2012;22:723-34.

112. Cooper BT, Holmes GK, Ferguson R, et al. Gluten-sensitive diarrhea without evidence of celiac disease. Gastroenterology 1980;79:801-6.

113. Verdu EF, Armstrong D, Murray JA. Between celiac disease and irritable bowel syndrome: the "no man's land" of gluten sensitivity. Am J Gastroenterol 2009;104:1587-94. 
114. Troncone R, Jabri B. Coeliac disease and gluten sensitivity. J Intern Med 2011;269:582-90.

115. Fasano A, Sapone A, Zevallos V, et al. Nonceliac gluten sensitivity. Gastroenterology 2015;148:1195-204.

116. Lundin KE. Non-celiac gluten sensitivity - why worry? BMC Med 2014;12:86.

117. Volta U, Caio G, De Giorgio R, et al. Non-celiac gluten sensitivity: a work-in-progress entity in the spectrum of wheat-related disorders. Best Pract Res Clin Gastroenterol 2015;29:477-91.

118. Volta U, Pinto-Sanchez MI, Boschetti E, et al. Dietary triggers in irritable bowel syndrome: Is there a role for gluten? Journal of Neurogastroenterology and Motility 2016;22:547-557.

119. Biesiekierski JR, Peters SL, Newnham ED, et al. No effects of gluten in patients with selfreported non-celiac gluten sensitivity after dietary reduction of fermentable, poorly absorbed, short-chain carbohydrates. Gastroenterology 2013;145:320-8 e1-3.

120. Makharia A, Catassi C, Makharia GK. The Overlap between Irritable Bowel Syndrome and Non-Celiac Gluten Sensitivity: A Clinical Dilemma. Nutrients 2015;7:10417-26.

121. Aziz I, Lewis NR, Hadjivassiliou M, et al. A UK study assessing the population prevalence of self-reported gluten sensitivity and referral characteristics to secondary care. Eur J Gastroenterol Hepatol 2014;26:33-9.

122. Volta U, Bardella MT, Calabro A, et al. An Italian prospective multicenter survey on patients suspected of having non-celiac gluten sensitivity. BMC Med 2014;12:85.

123. Ontiveros N, Lopez-Gallardo JA, Vergara-Jimenez MJ, et al. Self-Reported Prevalence of Symptomatic Adverse Reactions to Gluten and Adherence to Gluten-Free Diet in an Adult Mexican Population. Nutrients 2015;7:6000-15.

124. Cabrera-Chavez F, Dezar GVA, Islas-Zamorano AP, et al. Prevalence of self-reported gluten sensitivity and adherence to a gluten-free diet in argentinian adult population. Nutrients 2017;9 (1) (no pagination).

125. Cabrera-Chavez F, Granda-Restrepo DM, Aramburo-Galvez JG, et al. Self-Reported Prevalence of Gluten-Related Disorders and Adherence to Gluten-Free Diet in Colombian Adult Population. Gastroenterology Research and Practice 2016;2016 (no pagination).

126. Tanpowpong P, Broder-Fingert S, Katz AJ, et al. Predictors of dietary gluten avoidance in adults without a prior diagnosis of celiac disease. Nutrition 2015;31:236-8.

127. van Gils T, Nijeboer P, CE IJ, et al. Prevalence and Characterization of Self-Reported Gluten Sensitivity in The Netherlands. Nutrients 2016;8(11) pii: E714.

128. Carroccio A, Giambalvo O, Blasca F, et al. Self-Reported Non-Celiac Wheat Sensitivity in High School Students: Demographic and Clinical Characteristics. Nutrients 2017;9(7) pii: E771. doi: 10.3390/nu9070771.

129. Francavilla R, Cristofori F, Castellaneta S, et al. Clinical, serologic, and histologic features of gluten sensitivity in children. J Pediatr 2014;164:463-7 e1.

130. Vriezinga. Coeliac disease and gluten-related disorders in childhood. Nature reviews. Gastroenterology \& hepatology 2015;12:527-536.

131. Sapone A, Lammers KM, Casolaro V, et al. Divergence of gut permeability and mucosal immune gene expression in two gluten-associated conditions: celiac disease and gluten sensitivity. BMC Med 2011;9:23.

132. Brottveit M, Beitnes AC, Tollefsen S, et al. Mucosal cytokine response after short-term gluten challenge in celiac disease and non-celiac gluten sensitivity. Am J Gastroenterol 2013;108:842-50.

133. Volta U, Caio G, Karunaratne TB, et al. Non-coeliac gluten/wheat sensitivity: advances in knowledge and relevant questions. Expert Rev Gastroenterol Hepatol 2017;11:9-18.

134. Hollon J, Puppa EL, Greenwald B, et al. Effect of gliadin on permeability of intestinal biopsy explants from celiac disease patients and patients with non-celiac gluten sensitivity. Nutrients 2015;7:1565-76.

135. Di Sabatino A, Giuffrida P, Fornasa G, et al. Innate and adaptive immunity in self-reported nonceliac gluten sensitivity versus celiac disease. Digestive and Liver Disease 2016;48:745752. 
136. Barrett JS, Gearry RB, Muir JG, et al. Dietary poorly absorbed, short-chain carbohydrates increase delivery of water and fermentable substrates to the proximal colon. Aliment Pharmacol Ther 2010;31:874-82.

137. Volta U, Tovoli F, Cicola R, et al. Serological tests in gluten sensitivity (Nonceliac Gluten Intolerance). Journal of Clinical Gastroenterology 2012;46(8):680-5.

138. Kabbani TA, Vanga RR, Leffler DA, et al. Celiac disease or non-celiac gluten sensitivity? An approach to clinical differential diagnosis. Am J Gastroenterol 2014;109:741-6; quiz 747.

139. Catassi C, Elli L, Bonaz B, et al. Diagnosis of Non-Celiac Gluten Sensitivity (NCGS): The Salerno Experts' Criteria. Nutrients 2015;7:4966-77.

140. Zingone F, Bartalini C, Siniscalchi M, et al. Alterations in Diets of Patients With Nonceliac Gluten Sensitivity Compared With Healthy Individuals. Clin Gastroenterol Hepatol 2017;15:63-68.e2.

141. Tavakkoli A, Lewis SK, Tennyson CA, et al. Characteristics of patients who avoid wheat and/or gluten in the absence of Celiac disease. Dig Dis Sci 2014;59:1255-61.

142. Lovik A, Lundin KE. [Dietary treatment of coeliac disease and dermatitis herpetiformis]. Tidsskr Nor Laegeforen 2003;123:3237-40.

143. Newnham ED, Shepherd SJ, Strauss BJ, et al. Adherence to the gluten-free diet can achieve the therapeutic goals in almost all patients with coeliac disease: A 5-year longitudinal study from diagnosis. J Gastroenterol Hepatol 2016;31:342-9.

144. Garcia-Manzanares A, Lucendo AJ. Nutritional and dietary aspects of celiac disease. Nutr Clin Pract 2011;26:163-73.

145. Kupper C. Dietary guidelines and implementation for celiac disease. Gastroenterology 2005;128:S121-S127.

146. Case S. The gluten-free diet: how to provide effective education and resources. Gastroenterology 2005;128:S128-34.

147. Alvarez-Jubete L, Arendt EK, Gallagher E. Nutritive value and chemical composition of pseudocereals as gluten-free ingredients. Int J Food Sci Nutr 2009;60 Suppl 4:240-57.

148. Guttormsen V, Lovik A, Bye A, et al. No induction of anti-avenin IgA by oats in adult, diettreated coeliac disease. Scand.J.Gastroenterol. 2008;43:161-165.

149. Storsrud S, Olsson M, Arvidsson Lenner R, et al. Adult coeliac patients do tolerate large amounts of oats. Eur J Clin Nutr 2003;57:163-9.

150. Storsrud S, Hulthen LR, Lenner RA. Beneficial effects of oats in the gluten-free diet of adults with special reference to nutrient status, symptoms and subjective experiences. Br J Nutr 2003;90:101-7.

151. Thompson T, Dennis M, Higgins LA, et al. Gluten-free diet survey: are Americans with coeliac disease consuming recommended amounts of fibre, iron, calcium and grain foods? J Hum Nutr Diet 2005;18:163-9.

152. Hallert C, Grant C, Grehn S, et al. Evidence of poor vitamin status in coeliac patients on a gluten-free diet for 10 years. Aliment.Pharmacol.Ther. 2002;16:1333-1339.

153. Theethira TG, Dennis M. Celiac disease and the gluten-free diet: consequences and recommendations for improvement. Dig Dis 2015;33:175-82.

154. Shepherd SJ, Gibson PR. Nutritional inadequacies of the gluten-free diet in both recentlydiagnosed and long-term patients with coeliac disease. J Hum Nutr Diet 2013;26:349-58.

155. Talley NJ, Walker MM. Celiac Disease and Nonceliac Gluten or Wheat Sensitivity: The Risks and Benefits of Diagnosis. JAMA Intern Med 2017;177:615-616.

156. Halmos EP, Power VA, Shepherd SJ, et al. A diet low in FODMAPs reduces symptoms of irritable bowel syndrome. Gastroenterology 2014;146:67-75 e5.

157. Marsh A, Eslick EM, Eslick GD. Does a diet low in FODMAPs reduce symptoms associated with functional gastrointestinal disorders? A comprehensive systematic review and metaanalysis. European Journal of Nutrition 2016;55:897-906.

158. Barrett JS. How to institute the low-FODMAP diet. Journal of Gastroenterology and Hepatology 2017;32:8-10.

159. Gibson PR, Shepherd SJ. Personal view: food for thought--western lifestyle and susceptibility to Crohn's disease. The FODMAP hypothesis. Aliment Pharmacol Ther 2005;21:1399-409. 
160. Gibson PR, Shepherd SJ. Evidence-based dietary management of functional gastrointestinal symptoms: The FODMAP approach. J Gastroenterol Hepatol 2010;25:252-8.

161. Rumessen JJ. Fructose and related food carbohydrates. Sources, intake, absorption, and clinical implications. Scand J Gastroenterol 1992;27:819-28.

162. Shepherd SJ, Lomer MC, Gibson PR. Short-chain carbohydrates and functional gastrointestinal disorders. Am J Gastroenterol 2013;108:707-17.

163. Staudacher HM. Nutritional, microbiological and psychosocial implications of the low FODMAP diet. Journal of Gastroenterology and Hepatology 2017;32:16-19.

164. Staudacher HM, Whelan K, Irving PM, et al. Comparison of symptom response following advice for a diet low in fermentable carbohydrates (FODMAPs) versus standard dietary advice in patients with irritable bowel syndrome. J Hum Nutr Diet 2011;24:487-95.

165. Eswaran SL, Chey WD, Han-Markey T, et al. A Randomized Controlled Trial Comparing the Low FODMAP Diet vs. Modified NICE Guidelines in US Adults with IBS-D. American Journal of Gastroenterology. 2016;11.

166. de Roest RH, Dobbs BR, Chapman BA, et al. The low FODMAP diet improves gastrointestinal symptoms in patients with irritable bowel syndrome: a prospective study. Int $\mathrm{J}$ Clin Pract 2013;67:895-903.

167. Brottveit M, Raki M, Bergseng E, et al. Assessing possible celiac disease by an HLA-DQ2gliadin Tetramer Test. Am J Gastroenterol 2011;106:1318-24.

168. NAV. Rettskildene for Grunnstønad. Volume 2014, 2014. https://www.nav.no/rettskildene/Forside/Folketrygdloven/kapittel-6-grunnstonad-oghjelpestonad. Accessed February 20,2018.

169. Black AE. Critical evaluation of energy intake using the Goldberg cut-off for energy intake: basal metabolic rate. A practical guide to its calculation, use and limitations. Int J Obes Relat Metab Disord 2000;24:1119-30.

170. Leffler DA, Dennis M, Edwards George JB, et al. A simple validated gluten-free diet adherence survey for adults with celiac disease. Clin Gastroenterol Hepatol 2009;7:530-6, 536 e1-2.

171. Oberhuber G, Granditsch G, Vogelsang H. The histopathology of coeliac disease: time for a standardized report scheme for pathologists. Eur J Gastroenterol Hepatol 1999;11:1185-94.

172. Biesiekierski JR, Newnham ED, Shepherd SJ, et al. Characterization of Adults With a SelfDiagnosis of Nonceliac Gluten Sensitivity. Nutr Clin Pract 2014;29:504-509.

173. Brottveit M, Vandvik PO, Wojniusz S, et al. Absence of somatization in non-coeliac gluten sensitivity. Scand J Gastroenterol 2012;47:770-7.

174. Leffler DA, Dennis M, Edwards George J, et al. A validated disease-specific symptom index for adults with celiac disease. Clin Gastroenterol Hepatol 2009;7:1328-34, 1334 e1-3.

175. Meek R, Kelly AM, Hu XF. Use of the visual analog scale to rate and monitor severity of nausea in the emergency department. Acad Emerg Med 2009;16:1304-10.

176. Demoly P, Bousquet PJ, Mesbah K, et al. Visual analogue scale in patients treated for allergic rhinitis: an observational prospective study in primary care: asthma and rhinitis. Clin Exp Allergy 2013;43:881-8.

177. Wiklund IK, Fullerton S, Hawkey CJ, et al. An irritable bowel syndrome-specific symptom questionnaire: development and validation. Scand.J.Gastroenterol. 2003;38:947-954.

178. Spangenberg L, Brähler E. Bevölkerungsrepräsentative Neunormierung des Gießen-Tests (1492 Jahre). Psychotherapie Psychosomatik medizinische Psychologie 2011;61:e15-e18.

179. Mykletun A, Stordal E, Dahl AA. Hospital Anxiety and Depression (HAD) scale: factor structure, item analyses and internal consistency in a large population. Br J Psychiatry 2001;179:540-4.

180. Loge JH, Kaasa S. Short form 36 (SF-36) health survey: normative data from the general Norwegian population. Scand J Soc Med 1998;26:250-8.

181. Landis JR, Koch GG. The measurement of observer agreement for categorical data. Biometrics 1977;33:159-74.

182. de Vet HC, Mokkink LB, Terwee CB, et al. Clinicians are right not to like Cohen's kappa. Bmj 2013;346:f2125. 
183. Taavela J, Koskinen O, Huhtala H, et al. Validation of morphometric analyses of smallintestinal biopsy readouts in celiac disease. PLoS One 2013;8:e76163.

184. Di Sabatino A, Volta U, Salvatore C, et al. Small Amounts of Gluten in Subjects With Suspected Nonceliac Gluten Sensitivity: A Randomized, Double-Blind, Placebo-Controlled, Cross-Over Trial. Clin Gastroenterol Hepatol 2015;13(9):1604-12.e3.

185. Zanini B, Baschè R, Ferraresi A, et al. Randomised clinical study: gluten challenge induces symptom recurrence in only a minority of patients who meet clinical criteria for non-coeliac gluten sensitivity. Alimentary pharmacology \& therapeutics 2015;42:968-76.

186. Yao CK, Gibson PR, Shepherd SJ. Design of clinical trials evaluating dietary interventions in patients with functional gastrointestinal disorders. Am J Gastroenterol 2013;108:748-58.

187. Irvine EJ, Tack J, Crowell MD, et al. Design of Treatment Trials for Functional Gastrointestinal Disorders. Gastroenterology 2016;150:1469-1480.e1.

188. S. S. Cross-over Trials in Clinical Research, Ch 5 Normal data from designs with more than three treatments. Statistics in Practice 2002:157-186.

189. Shim JS, Oh K, Kim HC. Dietary assessment methods in epidemiologic studies. Epidemiol Health 2014;36:e2014009.

190. Vahedi K, Mascart F, Mary JY, et al. Reliability of antitransglutaminase antibodies as predictors of gluten-free diet compliance in adult celiac disease. Am.J.Gastroenterol. 2003;98:1079-1087.

191. Dickey W, Hughes DF, McMillan SA. Disappearance of endomysial antibodies in treated celiac disease does not indicate histological recovery. Am J Gastroenterol 2000;95:712-4.

192. Sategna-Guidetti C, Grosso S, Bruno M, et al. Reliability of immunologic markers of celiac sprue in the assessment of mucosal recovery after gluten withdrawal. J Clin Gastroenterol 1996;23:101-4.

193. Leffler DA, Edwards George JB, Dennis M, et al. A prospective comparative study of five measures of gluten-free diet adherence in adults with coeliac disease. Aliment Pharmacol Ther 2007;26:1227-35.

194. Nilsen MW. Gluten-free diet adherence amd micronutrient status: The celiac study in Eastern Norway (CELIEN). Department of Nutrition Research, Institute for Medical Research. Volume Master of Science: University of Oslo, 2012.

195. Tjønsø TN. Clinical Symptoms, Intestinal Histology and Nutrient Intake, The celiac study in Eastern Norway (CELIEN). Department of Nutrition Research, Institute for Medical Research. Volume Master of Science: University of Oslo, 2012.

196. Leffler DA, Edwards-George J, Dennis M, et al. Factors that influence adherence to a glutenfree diet in adults with celiac disease. Dig Dis Sci 2008;53:1573-81.

197. Biagi F, Andrealli A, Bianchi PI, et al. A gluten-free diet score to evaluate dietary compliance in patients with coeliac disease. Br.J.Nutr. 2009;102:882-887.

198. Asero R, Fernandez-Rivas M, Knulst AC, et al. Double-blind, placebo-controlled food challenge in adults in everyday clinical practice: a reappraisal of their limitations and real indications. Curr Opin Allergy Clin Immunol 2009;9:379-85.

199. Staudacher HM, Lomer MC, Anderson JL, et al. Fermentable carbohydrate restriction reduces luminal bifidobacteria and gastrointestinal symptoms in patients with irritable bowel syndrome. J Nutr 2012;142:1510-8.

200. Muraro A, Werfel T, Hoffmann-Sommergruber K, et al. EAACI Food Allergy and Anaphylaxis Guidelines: diagnosis and management of food allergy. Allergy 2014;69:10081025.

201. Niggemann B, Rolinck-Werninghaus C, Mehl A, et al. Controlled oral food challenges in children--when indicated, when superfluous? Allergy 2005;60:865-70.

202. Elli L, Tomba C, Branchi F, et al. Evidence for the Presence of Non-Celiac Gluten Sensitivity in Patients with Functional Gastrointestinal Symptoms: Results from a Multicenter Randomized Double-Blind Placebo-Controlled Gluten Challenge. Nutrients 2016;8 (2):84. doi: 10.3390/nu8020084. 
203. Vatn MH, Grimstad IA, Thorsen L, et al. Adverse reaction to food: assessment by doubleblind placebo-controlled food challenge and clinical, psychosomatic and immunologic analysis. Digestion 1995;56:421-8.

204. Hauser W, Gold J, Stallmach A, et al. Development and validation of the Celiac Disease Questionnaire (CDQ), a disease-specific health-related quality of life measure for adult patients with celiac disease. J.Clin.Gastroenterol. 2007;41:157-166.

205. Drossman DA, Patrick DL, Whitehead WE, et al. Further validation of the IBS-QOL: a disease-specific quality-of-life questionnaire. Am J Gastroenterol 2000;95:999-1007.

206. Camilleri M, Mangel AW, Fehnel SE, et al. Primary endpoints for irritable bowel syndrome trials: a review of performance of endpoints. Clin Gastroenterol Hepatol 2007;5:534-40.

207. Spiegel B, Bolus R, Harris LA, et al. Measuring irritable bowel syndrome patient-reported outcomes with an abdominal pain numeric rating scale. Aliment Pharmacol Ther 2009;30:1159-70.

208. Spiegel B, Camilleri M, Bolus R, et al. Psychometric evaluation of patient-reported outcomes in irritable bowel syndrome randomized controlled trials: a Rome Foundation report. Gastroenterology 2009; 137:1944-53.e1-3.

209. Boye B, Jahnsen J, Mokleby K, et al. The INSPIRE study: are different personality traits related to disease-specific quality of life (IBDQ) in distressed patients with ulcerative colitis and Crohn's disease? Inflamm Bowel Dis 2008;14:680-6.

210. Boye B, Lundin KE, Jantschek G, et al. INSPIRE study: does stress management improve the course of inflammatory bowel disease and disease-specific quality of life in distressed patients with ulcerative colitis or Crohn's disease? A randomized controlled trial. Inflamm Bowel Dis 2011;17:1863-73.

211. Svedlund J, Sjodin I, Dotevall G. GSRS--a clinical rating scale for gastrointestinal symptoms in patients with irritable bowel syndrome and peptic ulcer disease. Dig Dis Sci 1988;33:12934.

212. Villafuerte-Galvez J, Vanga RR, Dennis M, et al. Factors governing long-term adherence to a gluten-free diet in adult patients with coeliac disease. Aliment Pharmacol Ther 2015;42:75360 .

213. van Hees NJ, Van der Does W, Giltay EJ. Coeliac disease, diet adherence and depressive symptoms. J Psychosom Res 2013;74:155-60.

214. Hall NJ, Rubin G, Charnock A. Systematic review: adherence to a gluten-free diet in adult patients with coeliac disease. Aliment Pharmacol Ther 2009;30:315-330.

215. Rajpoot P, Sharma A, Harikrishnan S, et al. Adherence to gluten-free diet and barriers to adherence in patients with celiac disease. Indian J Gastroenterol 2015;34:380-6.

216. Bulloch B, Tenenbein M. Assessment of Clinically Significant Changes in Acute Pain in Children. Academic Emergency Medicine 2002;9:199-202.

217. Molina-Infante J, Carroccio A. Suspected Nonceliac Gluten Sensitivity Confirmed in Few Patients After Gluten Challenge in Double-Blind, Placebo-Controlled Trials. Clin Gastroenterol Hepatol 2017;15:339-348.

218. Lahdeaho ML, Kaukinen K, Laurila K, et al. Glutenase ALV003 attenuates gluten-induced mucosal injury in patients with celiac disease. Gastroenterology 2014;146:1649-58.

219. Sanders DS, Aziz I. Non-celiac wheat sensitivity: separating the wheat from the chat! Am J Gastroenterol 2012;107:1908-12.

220. Pinto-Sanchez MI, Verdu EF. Non-coeliac gluten sensitivity: are we closer to separating the wheat from the chaff? Gut 2016;65:1921-1922.

221. Gibson PR. Use of the low-FODMAP diet in inflammatory bowel disease. Journal of Gastroenterology and Hepatology 2017;32:40-42.

222. Kaukinen K, Turjanmaa K, Maki M, et al. Intolerance to cereals is not specific for coeliac disease. Scand J Gastroenterol 2000;35:942-6.

223. Carroccio A, Mansueto P, Iacono G, et al. Non-celiac wheat sensitivity diagnosed by doubleblind placebo-controlled challenge: exploring a new clinical entity. Am J Gastroenterol 2012;107:1898-906; quiz 1907. 
224. Gibson PR, Barrett JS. The concept of small intestinal bacterial overgrowth in relation to functional gastrointestinal disorders. Nutrition 2010;26:1038-43.

225. Erickson J, Korczak R, Wang Q, et al. Gastrointestinal tolerance of low FODMAP oral nutrition supplements in healthy human subjects: a randomized controlled trial. Nutr J 2017;16:35.

226. Halmos EP, Christophersen CT, Bird AR, et al. Diets that differ in their FODMAP content alter the colonic luminal microenvironment. Gut 2015;64:93-100.

227. de Punder K, Pruimboom L. The dietary intake of wheat and other cereal grains and their role in inflammation. Nutrients 2013;5:771-87. 



\title{
APPENDICES
}

\author{
I. Ethical approvals \\ II. Participant consent forms \\ III. Notification of imported foodstuff \\ IV. Questionnaires
}





\section{UNIVERSITETET I OSLO \\ DET MEDISINSKE FAKULTET}

Lege, gastroenterolog dr.med. Knut E.A.Lundin

Medisinsk avdeling

Rikshospitalet

Rikshospitalet-Radiumhospitalet HF

Dato: 12.09 .06

Deres ref.:

Vår ref.: S-06114
Regional komité for medisinsk forskningsetikk

Sør- Norge (REK Sør)

Postboks 1130 Blindern

NO-0318 Oslo

Telefon: 22844666

Telefaks: 22844661

E-post: rek-2@medisin.uio.no

Nettadresse: www.etikkom.no

\section{S-06114 Cøliakidiagnose i en blodprøve}

Vi viser til brev datert 15.6.2006 vedlagt revidert informasjonsskriv med samtykkeerklæring.

Komiteen tar svar på merknader til etterretning.

Komiteen har ingen merknader til skjema for opprettelse av forskningsbiobank.

Komiteen har ingen merknader til revidert pasientinformasjon og samtykkeerklæring.

Komiteen tilrår at prosjektet gjennomføres og at forskningsbiobank opprettes.

Komiteen videresender skjema for opprettelse av forskningsbiobank og informasjonsskrivet samt komiteens vedtak til Sosial- og helsedirektoratet for endelig behandling av opprettelse av forskningsbiobanken.

Vi ønsker lykke til med prosjektet.

Med vennlig hilsen

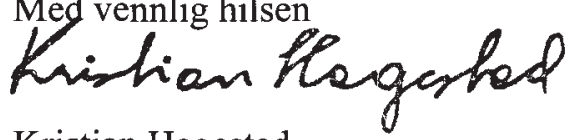

Kristian Hagestad

Fylkeslege cand.med., spes. i samf.med

Fungerende leder

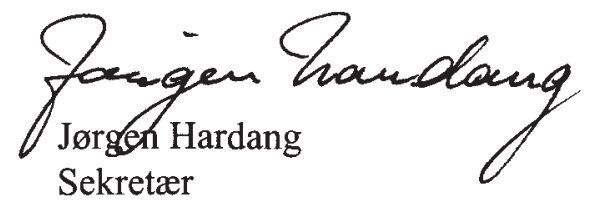

Kopi: Sosial- og helsedirektoratet, Postboks 7000, St. Olavs plass, 0130 Oslo 
Postadresse:

Trondheimsveien 235

0514 Oslo

\section{PERSONVERNOMBUDETS TILRÅDING}

Sentralbord:

02770
Til:
Gry Irene Skodje
Kopi:
Knut Lundin
Fra:
Personvernombudet ved Oslo universitetssykehus
Saksbehandler:
Henrik Lindgren Jensen
Dato:
22.04.2015
Offentlighet:
Ikke unntatt offentlighet
Sak:
Personvernombudets tilråding til innsamling og
databehandling av personopplysninger
Saksnummer/
ePhortenummer:

Org.nr:

NO 993467049 MVA

www.oslo-universitetssykehus.no

\section{Personvernombudets tilråding til innsamling og behandling av personopplysninger for prosjektet "Glutenprovokasjon ved mistent ikke-cøliakisk glutensensitivitet"}

Viser til innsendt melding om behandling av personopplysninger / helseopplysninger. Det følgende er personvernombudets tilråding av prosjektet.

Med hjemmel i personopplysningsforskriften $\S 7-12$, jf. helseregisterloven $\S 36$, har Datatilsynet ved oppnevning av personvernombud ved Oslo Universitetssykehus (OUS), fritatt sykehuset fra meldeplikten til Datatilsynet. Behandling og utlevering av person/helseopplysninger meldes derfor til sykehusets personvernombud.

Databehandlingen tilfredsstiller forutsetningene for melding gitt $\mathrm{i}$ personopplysningsforskriften $\S 7-27$ og er derfor unntatt konsesjon.

Personvernombudet tilrår at prosjektet gjennomføres under forutsetning av følgende:

1. Databehandlingsansvarlig er Oslo universitetssykehus HF ved adm. dir.

2. Avdelingsleder eller klinikkleder ved OUS har godkjent studien.

3. Behandling av personopplysningene / helseopplysninger i prosjektet skjer i samsvar med og innenfor det formål som er oppgitt i meldingen.

4. Data lagres som oppgitt i meldingen. Annen lagringsform forutsetter gjennomføring av en risikovurdering som må godkjennes av Personvernombudet.

5. Vedlagte samtykke benyttes, inklusive markerte tillegg og endringer foretatt av personvernombudet. Eventuelle fremtidige endringer som berører formålet, utvalget inkluderte eller databehandlingen må forevises personvernombudet før de tas i bruk.

6. Kryssliste som kobler avidentifiserte data med personopplysninger lagres som angitt i meldingen og oppbevares separat på prosjektleders avlåste kontor.

7. Dersom formålet eller databehandlingen endres må personvernombudet informeres om dette. 
8. Kontaktperson for prosjektet skal hvert tredje år sende personvernombudet ny melding som bekrefter at databehandlingen skjer i overensstemmelse med opprinnelig formål og helseregisterlovens regler.

9. Data slettes eller anonymiseres ved prosjektslutt01.01.2028 ved at krysslisten slettes og eventuelle andre identifikasjonsmuligheter i databasen fjernes. Når formålet med registeret er oppfylt sendes melding om bekreftet sletting til personvernombudet.

Prosjektet er registrert i sykehusets offentlig tilgjengelig database over forsknings- og kvalitetsstudier.

Lykke til med prosjektet!

Med vennlig hilsen

Henrik Lindgren Jensen

Personvernrådgiver

Oslo universitetssykehus HF

Stab pasientsikkerhet og kvalitet

Seksjon for personvern og informasjonssikkerhet

Epost: personvern@,oslo-universitetssykehus.no

Web: www.oslo-universitetssykehus.no/personvern 


\begin{tabular}{|c|c|c|}
\hline \multicolumn{2}{|c|}{$\begin{array}{l}\text { Akershus } \\
\text { universitetssykehus }\end{array}$} & Akershus universitetssykehus $\mathrm{HF}$ \\
\hline & & $\begin{array}{l}\text { Postadresse: } \\
\text { Postboks 95 } \\
1478 \text { Lørenskog }\end{array}$ \\
\hline \multicolumn{2}{|c|}{ REK-PROSJEKT } & Sentralbord: \\
\hline \multicolumn{2}{|c|}{ PERSONVERNOMBUDETS UTTALELSE TIL } & 02900 \\
\hline \multicolumn{2}{|c|}{ UTLEVERING AV PASIENTJOURNAL } & $\begin{array}{l}\text { Org.nr: } \\
\text { NO } 983971636 \text { MVA }\end{array}$ \\
\hline Til: & $\begin{array}{l}\text { Knut Lundin, prof overlege, avd for } \\
\text { transplantasjonsmedisin, OUS HF og Gry Skodje, } \\
\text { klinisk ernæringsfysiolog }\end{array}$ & www.ahus.no \\
\hline Kopi: & $\begin{array}{l}\text { Kst Geir Arne Larsen, Gastrokirurgisk avdeling } \\
\text { Jane Beate Bjur, seksjonsjef,Journalarkivet }\end{array}$ & \\
\hline Fra: & $\begin{array}{l}\text { Personvernombudet ved } \\
\text { Akershus universitetssykehus }\end{array}$ & \\
\hline Saksbehandler: & Marianne B Blair & \\
\hline Dato: & 04.07 .2015 & \\
\hline Offentlighet: & Ikke unntatt offentlighet & \\
\hline Sak: & $\begin{array}{l}\text { Personvernombudets uttalelse til innsamling og } \\
\text { behandling av personopplysninger }\end{array}$ & \\
\hline $\begin{array}{l}\text { Saksnummer/ } \\
\text { Personvernnumr }\end{array}$ & $15-127$ & \\
\hline
\end{tabular}

Personvernombudets uttalelse till innsamling og behandling av personopplysninger for forskning i prosjektet "Gluten- og fodmap-provokasjon ved glutensensitivitet uten cøliaki"

Prosjektbeskrivelse:

Bakgrunn:

Betegnelsen glutensensitivitet omfatter cøliaki, hveteallergi og ikke-cøliakisk

glutensensitivitet. Felles for tilstandene er behandling med gluten- og hvetefri kost. Coliaki og hveteallergi er veldefinerte diagnoser med standardisert utredning. Ikke-coliakisk glutensensitivitet (NCGS) mangler presis definisjon, utredningen er ikke standardisert og sykdomsmekanismen er ukjent. Tilstanden er klinisk lik coliaki, men uten intestinal inflammasjon eller positiv serologi. Det foregår internasjonal forskning for å øke kunnskapen NAV innrømmer grunnstønad ved positiv test på glutenprovokasjon hos spesialist, men definerer ikke hvordan provokasjonen skal utfores. Oslo

Universitetssykehus, Rikshospitalet har i flere år utredet disse pasientene ved hjelp av standardisert, åpen glutenprovokasjon, der positiv test bekrefter NCGS. Metoden har svakheter som vi ønsker å forbedre ved à prøve ut en dobbeltblindet placebokontrollert provokasjon med gluten og fodmap hver for seg.

Målsetning:

A forbedre utredningen av glutensensitivitet uten coliaki ved à utvikle en standardisert og objektiv diagnostikk til bruk i klinikken: dobbeltblindet placebokontrollert glutenprovokasjon

Viser til innsendt melding om behandling av personopplysninger / helseopplysninger. Det følgende er et formelt svar på meldingen og gjelder kun utlevering av pasientopplysninger i prosjekt der Akershus universitetssykehus HF ikke har noen annen rolle. Forutsetningene nedenfor må være oppfylt før rekruttering av pasienter til studien kan starte. 
Med hjemmel i Personopplysningsforskriftens § 7-12 jf. Personopplysningsloven $\S 31$, har Datatilsynet, ved oppnevning av personvernombud, fritatt sykehuset fra meldeplikten til Datatilsynet. Forskningsprosjekter (studier) som omfatter høsting, lagring og tilgjengeliggjøring samt behandling av person-/helseopplysninger, meldes derfor til sykehusets personvernombud, se særlig helseregisterloven $\S 3$ om formål og $\S 6$ om alminnelige vilkår for å behandle helseopplysninger.

Personvernombudet har vurdert det til at den planlagte databehandlingen av personopplysninger / helseopplysninger tilfredsstiller de krav som stilles i helseforskningsog personvernlovgivningen. Personvernombudet har ingen innvendinger til at den planlagte utleveringen av personopplysninger / helseopplysninger som kan utføreses under forutsetning av følgende:

1. Forskningsansvarlig / databehandlingsansvarlig er Oslo universitetssykehus HF ved adm. direktør.

2. Avdelingsleder og forskningsansvarlig i Gastrokirurgisk avdeling blir informert ved kopi av tilrådingen.

3. Studien er vurdert og godkjent av Regional komité for medisinsk og helsefaglig forskningsetikk (REK), og eventuelle merknader må følges.

4. Vedlagte pasientsamtykke er ifølge REK tilstrekkelig til å innhente informasjon fra eksterne.

5. Pasientopplysningene lagres som oppgitt i meldingen. Kodeliste som kobler avidentifiserte data (indirekte identifiserbare helseopplysninger) med personopplysninger lagres som angitt i meldingen og oppbevares separat nedlåst på adgangsbegrenset rom på sykehuset eller elektronisk som separat fil på tilgangsstyrt prosjektområde på forskningsserver med tilstrekkelige sikkerhetsinnretninger.

6. Behandling av personopplysningene / helseopplysninger (sensitive opplysninger) $\mathrm{i}$ prosjektet skjer i samsvar med og innenfor det formål som er oppgitt i meldingen og fremlagt dokumentasjon forøvirig.

7. Prosjektslutt er 31.03.2017. Av dokumentasjonshensyn skal opplysningene likevel bevares inntil 31.12.2028 forutsatt overensstemmende med vedtak fra REK da skal data slettes eller anonymiseres ved at kodelisten slettes og eventuelle andre identifikasjonsmuligheter i databasen fjernes (senest 6 mnd etter sluttdato).

8. Dersom formålet, utvalget av inkluderte eller databehandlingen endres må tillatelse innhentes fra REK fra forskningsansvarlig.

Utleveringen er registrert i sykehusets offentlig tilgjengelig database over forsknings- og kvalitetsstudier.

Lykke til med studien!

Med vennlig hilsen

Personvernombud

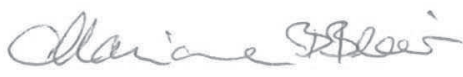

Marianne B Blair

Akershus universitetssykehus HF

Epost: personvern@ahus.no

Web: www.ahus.no 


\begin{tabular}{|c|c|c|c|c|}
\hline Region: & Saksbehandler: & Telefon: & Vår dato: & Vår referanse: \\
\hline \multirow[t]{2}{*}{ REK sør-øst } & Anette Solli Karlsen & 22845522 & 16.09 .2014 & $\begin{array}{l}\text { 2013/1237/REK sør-øst } \\
\text { A }\end{array}$ \\
\hline & & & Deres dato: & Deres referanse: \\
\hline
\end{tabular}

Knut E. A. Lundin

Seksjon for gastromedisin, Oslo Universitetssykehus HF

\section{3/1237 Gluten provokasjon ved cøliaki og gluten sensitivitet}

Forskningsansvarlig: Oslo Universitetssykehus HF

Prosjektleder: Knut E. A. Lundin

Vi viser til søknad om prosjektendring datert 04.09.2014 for ovennevnte forskningsprosjekt. Søknaden er behandlet av leder for REK sør-øst på fullmakt, med hjemmel i helseforskningsloven § 11.

\section{Vurdering}

REK har vurdert følgende endringer i prosjekt:

-Endring i studiedesign. Prosjektet omfatter nå en 3-armet utprøving.

-Utvidelse av antall forskningsdeltakere: Det planlegges å inkludere 66 deltakere i prosjektet (tidligere godkjent 40).

-Innsamling av nytt biologisk materiale. Deltakere skal samle avføringsprøver ved 4 anledninger, disse skal inngå i prosjektets biobank og undersøkes for korte fettsyrer, $\mathrm{pH}$, total bakterieforekomst og bakteriesammensetning.

-Forlenget provokasjonsperiode. Provokasjonsperioden forlenges fra 3 til 7 dager.

-revidert informasjonsskriv i forhold til endringer beskrevet ovenfor.

Komiteens leder har vurdert søknaden og har ingen innvendinger til de endringer som er beskrevet.

\section{Vedtak}

Komiteen godkjenner med hjemmel i helseforskningsloven $\S 11$ annet ledd at prosjektet videreføres i samsvar med det som fremgår av søknaden om prosjektendring og i samsvar med de bestemmelser som følger av helseforskningsloven med forskrifter.

Dersom det skal gjøres ytterligere endringer i prosjektet i forhold til de opplysninger som er gitt i søknaden, må prosjektleder sende ny endringsmelding til REK.

Av dokumentasjonshensyn skal opplysningene oppbevares i 5 år etter prosjektslutt. Opplysningene skal oppbevares avidentifisert, dvs. atskilt i en nøkkel- og en datafil. Opplysningene skal deretter slettes eller anonymiseres, senest innen et halvt år fra denne dato. Forskningsprosjektets data skal oppbevares forsvarlig, se personopplysningsforskriften kapittel 2, og Helsedirektoratets veileder for «Personvern og informasjonssikkerhet i forskningsprosjekter innenfor helse- og omsorgssektoren».

Prosjektet skal sende sluttmelding til REK, se helseforskningsloven $\S 12$, senest 6 måneder etter at prosjektet er avsluttet.

Komiteens vedtak kan påklages til Den nasjonale forskningsetiske komité for medisin og helsefag, jf.

Besøksadresse:

Gullhaugveien 1-3, 0484 Oslo
Telefon: 22845511

E-post: post@helseforskning.etikkom.no Web: http://helseforskning.etikkom.no/ saksbehandlingen, bes adressert til REK sør-øst og ikke til enkelte personer
Kindly address all mail and e-mails to the Regional Ethics Committee, REK sør-øst, not to individual staff 
helseforskningsloven $\S 10$ tredje ledd og forvaltningsloven $\S 28$. En eventuell klage sendes til REK sør-øst A. Klagefristen er tre uker fra mottak av dette brevet, jf. forvaltningsloven $\S 29$.

Med vennlig hilsen

Knut Engedal

Professor dr. med.

Leder

Anette Solli Karlsen

Komitesekretær

Kopi til:pline@ous-hf.no; oushfdlgodkjenning@ous-hf.no 


\section{Generell forskningsbiobank}

\section{Tarmsykdommer}

Prosjektbeskrivelse:

Formålet til forskningsgruppene som arbeider med tarmsykdommer ved Oslo Universitetssykehus Rikshospitalet er å; 1)kartlegge arvelige og miljømessige faktorer og forhold ved kroppens immunsystem som kan bidra til at tarmsykdommer oppstår og som kan være av betydning for forløpet av sykdommene og assosierte tilstander, og 2)forbedre diagnostikk og behandling av tarmsykdommer. Til slike studier vil vi ha behov for å bygge opp en biobank bestående av flere typer biologisk materiale. Totalt tre ulike forskningsgrupper vil i første omgang søke REK om prosjektgodkjenning for bruk av materialet i biobanken. Disse arbeider med dels ulike aspekter ved tarmsykdommmer og det er således ikke naturlig å søke om en prosjektbiobank. Det kan også finnes andre miljøer ved Oslo Universitetssykehus Rikshospitalet eller samarbeidende institusjoner som vil ha nytte av materialet i sin forskning.

(Redigert av REK)

Ref. nr.: 2012/341 Startdato for innsamling av materiale: 01.05 .2012

Behandlingsstatus: Under behandling

Ansvarshavende: Knut E. A. Lundin

Forskningsansvarlig(e): Oslo Universitetssykehus Rikshospitalet

Finansieringskilder: Norsk senter for primær skleroserende cholangitt

\section{Behandlet i REK}

Dato REK

15.03.2012REK sør-øst

15.02.2017REK sør-øst

$\underline{15.02 .2017 R E K ~ s ø r-ø s t ~}$ 
Utfylt av: GRY IRENE SKODJE (for GRY IRENE SKODJE)

Adresse: GRY IRENE SKODJE, HOVSETERVEIEN 64 B 0768 OSLO

\section{Ny importør av næringsmidler}

Her ser du en oppsummering av hva du har fylt inn i skjemaet - det er ikke innsendt ennå.

\section{Du har registrert/meldt om nytt tilsynsobjekt av type Import av næringsmidler}

\section{Tilsynsobjekt: Import av næringsmidler}

Generelle opplysninger om tilsynsobjektet

Navn på benyttet skjema Ny importør av næringsmidler

Navn på tilsynsobjektet Import av næringsmidler

Aktivitet Import av næringsmidler

Beskrivelse Muslibarer produsert ved Monash University i Melbourne, Australia, til bruk i klinisk studie på Rikshospitalet.

Kontaktperson

Gry Skodje

\section{Detaljer om tilsynsobjektet}

Importøren varsler også i

Traces

$\mathrm{Nei}$

\section{Registrerte varegrupper}

19042010

Musli-preparater på basis av ustekte flak av korn

Registrerte første mottakere

GRY IRENE SKODJE 
Deres ref:

Vår ref:

Dato:

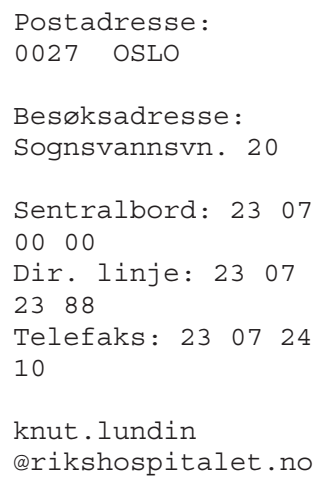

\section{FORESPØRSEL OM DELTAGELSE I FORSKNINGSPROSJEKT GLUTENPROVOKASJON VED "USIKKER CØLIAKI" PASIENTINFORMASJON}


Vi vil spørre deg om du vil delta i et forskningsprosjekt for å vurdere nytten av en blodprøve hos pasienter der cøliakidiagnosen er usikker. Deltakelse er helt frivillig.

For å vite om du kan delta i denne studien må du ha en spesiell vevstype som kalles DQ2, denne vevstypen finnes hos nesten alle med cøliaki, og hos ca $25 \%$ av den norske befolkningen.

Vevstypen finner man ved å ta en vanlig blodprøve. Dersom du har denne vevstypen, kan du delta i studien.

Før du bestemmer deg om du vil delta, må du lese dette informasjonsskrivet nøye. Om du bestemmer deg for å delta i denne studien, må du signere på den vedlagte samtykkeerklæringen. Selv om du takker ja til å delta i studien, kan du når som helst trekke deg uten å oppgi noen grunn. Dette vil ikke få følger i forhold til dine rettigheter til utredning og behandling som du måtte ha i forhold til pasientrettighetsloven.

Bakgrunn: Cøliaki er en tynntarmsykdom der tarmtottene er skadet. Dermed blir tarmens evne til å oppta fødemidler redusert. Pasientene kan få diaré og symptomer som skyldes redusert opptak av jern, folsyre og kalk. Cøliaki utløses hos disponerte individer ved inntak av kornslag som hvete, rug og bygg. Man har lenge lett etter hvilke deler av hvete som er skadelig for tarmen, og vår forskningsgruppe har gjort flere avgjørende gjennombrudd. Vi vet i dag at sykdommen kommer i stand ved at immunapparatet reagerer på små protein biter (peptider) fra hvete gluten. Grunnpilaren i behandlingen av cøliaki er glutenfri diett. Når gluten ikke lenger inntas vil immunapparatet ikke lenger reagere, og betennelsen i slimhinnen gå tilbake. Et problem oppstår når cøliakipasienter begynner med glutenfri diett før diagnosen er sikker. Tarmen vil da bli normal og det er nødvendig med langvarig provokasjon med gluten for at tarmen igjen skal bli skadet og legen kan stille diagnosen basert på undersøkelsen av vevsprøver tatt fra tynntarmen under gastroskopi.

Hensikt med prosjektet: $\AA$ undersøke om det er mulig å finne sykdomsspesifikke celler i blod hos voksne pasienter med "usikker cøliaki" etter at de har inntatt glutenholdige måltider. Vi håper at denne blodprøven i framtida kan bidra i diagnostikk av pasienter med "usikker cøliaki". Samtidig vil vi se etter forandringer i vevsprøver tatt fra tynntarmen og i tynntarmsfunksjonen målt ved pusteprøve.

Tidsrom: I løpet av 2006-2007

Metoder: Vi vil undersøke 50 pasienter med "usikker cøliaki". Det vil si pasienter som lever på glutenfri diett, uten å ha fått påvist cøliaki med vevsprøver fra tynntarm tatt under normalt kosthold. I tillegg vil vi undersøke 10 pasienter med kjent cøliaki som kontrollpersoner. Hos forsøkspersonene som samtykker i dette, gjør vi først en gastroskopi ("kikkertundersøkelse" av magesekk og øvre del av tynntarm) med taking av vevsprøver fra tynntarmen. Gastroskopiundersøkelsen oppleves ofte som litt ubehagelig, men er gjort på noen få minutter. Taking av vevsprøver medfører som regel ikke ekstra ubehag. En slik gastroskopi er rutine i diagnostikk av cøliaki. Når man tar vevsprøve fra tynntarmen kan det være en risiko for blødning, men denne er ansett som svært liten. Vi tar i denne sammenheng ikke vevsprøver fra pasienter med kjent blødningstendens eller som bruker blodfortynnende medisiner på en slik måte at det gir blødningsrisiko. Det er svært sjelden man får komplikasjoner etter en slik vevsprøvetaking.

Få uker etter dette vil forsøkspersonene spise fire skiver brød tre dager på rad. Bortsett fra disse brødskivene, vil man spise glutenfri kost som vanlig. Vi vil ta blodprøve like før dette og tre dager etter at pasienten har spist den siste porsjonen med brød. Blodprøvene vi tar vil så bli undersøkt med avanserte metoder for å lete etter effekter av glutenprovokasjonen. Vi vil også gjøre ny gastroskopi med taking av vevsprøver fra tynntarmen og ny pusteprøve $\mathrm{Vi}$ anser risikoen for den enkelte pasient i denne studien som meget liten. Glutenprovokasjon kan gi kortvarig ubehag for pasientene, slik som kan skje når en pasient med cøliaki får i seg mindre mengder gluten. Det er 
imidlertid meget lite sannsynlig at disse negative effektene vil vare mer enn noen få dager. I forbindelse med glutenprovokasjonen ber vi deg fylle ut et spørreskjema med registrering av fysiske og psykiske symptomer.

Om du skulle få respons på glutenprovokasjonen, i form av endringer i vevsprøver fra tynntarm eller påvisning av glutenspesifikke celler i blod, vil vi anbefale en videre provokasjon. En videre glutenprovokasjon bør vare 8 uker, dette tilsvarer det spesialavdelinger i fordøyelsessykdommer anbefaler. Etter denne blir det en ny gastroskopi.

Etiske og personverns aspekter: Studien er forelagt den regionale etiske komité, som er en helt uavhengig instans, og som ikke har innvendinger mot at studien gjennomføres. Det opprettes en såkalt forskningsbiobank ledet av dr.med. Knut E. A. Lundin. Om en forsøksperson skulle ønske å tilbakekalle samtykket kan vedkommende kreve det biologiske materialet destruert og å slette eller utlevere helse- og personopplysninger. Dette kan ikke gjøres om opplysningene allerede har inngått i vitenskaplige arbeider. En forsøksperson kan når som helst trekke seg fra studien, uten å begrunne dette nærmere. Dette vil ikke få konsekvenser for videre utredning og behandling i helsevesenet. Pasientkontakten vil bli registrert i sykehusets journalsystem. Etter studien planlegger vi å ta vare på det biologiske materialet i fem år med tanke på mulige oppfølgingsstudier. Forskerne i studien har taushetsplikt.

Økonomiske aspekter: Det legges ikke opp til å utbetale noe honorar til forsøkspersonene, men vi kan dekke reiseutgifter eller andre utgifter til studien. Ingen av legene som er involvert mottar noen form for honorar fra noe firma for studien.

\section{Aktuelle telefonnumre:}

Dr Margit Brottveit, gastromedisinsk avdeling, Ullevål universitetssykehus, tlf 22118592 (kontor), 957 65633(mobil). Dr. Knut E. A. Lundin, Medisinsk avdeling, Rikshospitalet, Tel 23072388 (sentralbord), 230724 00(gastrolab), 90980325 (mobil). 


\section{SAMTYKKE-ERKL/ERING}

Jeg har fått utlevert og lest den utdelte pasientinformasjon, og har fått muntlig informasjon om forsøket.

Jeg samtykker i å delta i forsøket. Jeg er klar over at mitt samtykke ikke hindrer meg i når som helst å trekke meg fra forsøket uten å oppgi grunn. Hvis jeg trekker meg fra forsøket vil dette ikke få noen konsekvenser for sykehusets oppfølging av min tilstand.

Oslo,

Underskrift

Navn (blokkbokstaver):

Telefon (privat):

Telefon (arbeid):

Telefon (mobil):

Det attesteres at informasjon er gitt

Oslo,

$\overline{\text { Underskrift (ansvarlig lege) }}$ 


\section{Forespørsel om deltakelse i forskningsprosjektet}

\section{"Glutenprovokasjon ved mistenkt glutensensitivitet uten coliaki - en retrospektiv studie"}

\section{Bakgrunn}

Dette er et spørsmål til deg om å delta i en forskningsstudie for å evaluere utredningsmetoden ved mistenkt glutensensitivitet uten cøliaki (NCGS). Gastromedisinsk poliklinikk og Seksjon for klinisk ernæring, Rikshospitalet har utredet pasienter med mistenkt NCGS ved hjelp av åpen glutenprovokasjon siden 2009. Det er en relativt ny utredning som brukes i liten grad på andre sykehus enn Rikshospitalet. Det er derfor behov for å gjøre en systematisk gjennomgang og evaluere metoden.

Hovedhensikent med studien er å evaluere åpen glutenprovokasjon ved mistenkt glutensensitivitet uten cøliaki utført ved Oslo Universitetssykehus (OUS) Rikshospitalet fra 2009 og fortløpende.

Du blir forespurt om deltakelse fordi du har blitt utredet med denne metoden på Rikshospitalet.

Leger og forskere ved OUS arbeider hele tiden for å forbedre forståelsen av årsaken til tarmsykdommer og for å forbedre diagnostikk og behandling av slike tilstander. Resultatene av forskningen kan gi oss verdifull kunnskap og forståelse av mekanismer som kan ha betydning for framtidig oppfølging og behandling av pasientene.

\section{Hva innebærer studien?}

Deltakelse i studien innebærer at du gir tillatelse til at vi kan bruke opplysninger fra din journal som omhandler utredningen av NCGS. Opplysningene som vil bli lagret er informasjon fra utredningen hos lege og klinisk ernæringsfysiolog og resultatene fra glutenprovokasjonen. Det vil også bli lagret blodprøvesvar og svar på gastroskopi dersom dette er utført.

\section{Mulige fordeler og ulemper}

Du vil ikke ha noen spesielle fordeler av studien, men erfaringer fra studien vil senere kunne hjelpe andre med samme diagnose.

\section{Hva skjer med informasjonen om deg?}

Informasjonen som registreres om deg skal kun brukes slik som beskrevet i hensikten med studien. Alle opplysningene vil bli behandlet uten navn og fødselsnummer/direkte gjenkjennende opplysninger. En kode knytter deg til dine opplysninger gjennom en navneliste. Det er kun autorisert personell knyttet til prosjektet som har adgang til navnelisten og som kan finne tilbake til deg. Det vil ikke være mulig å identifisere deg $i$ resultatene av studien når disse publiseres.

Hvis du sier ja til å delta i studien, har du rett til å få innsyn i hvilke opplysninger som er registrert om deg. Du har videre rett til å få korrigert eventuelle feil i de opplysningene vi har registrert. Dersom du trekker deg fra studien, kan du kreve å få slettet innsamlede opplysninger. Opplysningene blir senest slettet i 2028.

\section{Frivillig deltakelse}

Det er frivillig å delta i studien. Dersom du ikke ønsker å delta, trenger du ikke å oppgi noen grunn, og det får ingen konsekvenser for den videre behandlingen du får ved sykehuset.

Dersom du ønsker å delta, undertegner du samtykkeerklæringen på neste side. Om du nå sier ja til å delta, kan du senere trekke tilbake ditt samtykke uten at det påvirker din øvrige behandling på sykehuset. Dersom du senere ønsker å trekke deg, kan du kontakte prosjektleder Knut Lundin på 23072400 eller 23072404. 


\section{Samtykke for deltakelse i studien:}

\section{"Glutenprovokasjon ved mistenkt glutensensitivitet uten cøliaki - en retrospektiv studie"}

Jeg er villig til å delta i studien

(Navn, blokkbokstaver, evt navnelapp)

(Dato, signatur)

\section{Bekreftelse på at informasjon er gitt deltakeren i studien}

Jeg bekrefter å ha gitt informasjon om studien

Klinisk klinisk ernæringsfysiolog/stipendiat

Rikshospitalet, OUS

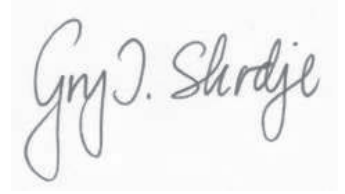

(Signatur)
Klinisk ernæringsfysiolog

Ernæringspoliklinikken, OUS 


\section{Forespørsel om deltakelse i forskning "Mekanismene for cøliaki - delprosjekt 14 dagers provokasjon med gluten"}

\section{Bakgrunn og hensikt}

Dette er et spørsmål til deg om å delta i forskning for å øke kunnskapen om tynntarmsykdommer med spesielt fokus på cøliaki. Leger og forskere ved Oslo Universitetssykehus (OUS) arbeider hele tiden for å forbedre forståelsen av årsaken til tarmsykdommer og for å forbedre diagnostikk og behandling av slike tilstander. Resultatene av forskningen kan gi oss verdifull kunnskap og forståelse av mekanismer som kan ha betydning for framtidig oppfølging og behandling av pasientene.

\section{Forløp studieplan:}

I denne studien ønsker vi å undersøke hvor raskt totteforandringene kommer tilbake, etter at cøliakere re-introduserer gluten i kosten. Vi ønsker også å undersøke hvordan immunsystemet i tarmen aktiveres i løpet av en slik provokasjon. Studien innebærer at du spiser gluten i to uker. Du vil først snakke med studielegen og få nøye informasjon. Det vil bli tatt blodprøver ved første konsultasjon. Deretter skal det inntas glutenholdig brød daglig i to uker. Du vil få nærmere beskjed om hvilken type brød du skal spise, bortsett fra dette inntas glutenfri kost som før. Det vil bli tatt blodprøver også etter at du har spist gluten. Du må regne med ubehag mens du spiser gluten, dette er vanligvis forbigående og du vil få informasjon om hvordan du skal forholde deg til symptomer under studien. Cøliakere med kraftig reaksjon på gluten bør ikke delta i studien, dette vil bli tatt opp i samtalen med studielegene. Det er ønskelig å utføre gastroskopi før og etter provokasjon med gluten, men det er mulig å delta i studien også uten å stille til gastroskopi. Alle prosedyere blir utført på OUS Rikshospitalet av studielegene. Alle deltagere får informasjon om timeplanen i studien, og det er selvsagt frivillig å delta. Man kan også trekke seg mens studien pågår, uten å oppgi grunn, men studielegene vil bistå med medisinsk hjelp og råd.

\section{Hva innebærer deltakelse i studiene?}

I forbindelse med dette prosjektet er det nødvendig å ta prøver av blod, avføring og vevsprøver fra tarmene. Den aktuelle studie med 14 dagers provokasjon med gluten er nært knyttet til vår øvrige cøliakiforskning, og alt biologisk materiale fra denne studien kan komme til nytte i våre $\emptyset$ vrige prosjekter. Vi spør deg derfor om du vil gi tillatelse til:

- at deler av prøvene som blir til overs kan oppbevares til senere bruk i forskning på tarmsykdommer som ledd i vår overordnede studie "Immunologisk basis for cøliaki".

- at blod- og/eller vevsprøver som allerede finnes ved OUS laboratorier, tatt i forbindelse med tidligere undersøkelser og behandling eller forskningsprosjekt, også kan benyttes i forskningen

- å ta blodprøver til studier av arvestoff (gener) og andre komponenter av mulig betydning for utvikling av tarmsykdom

- å ta vevsprøver fra tarmslimhinnen,

\section{Mulige fordeler og ulemper}

Resultatene av forskningen vil som hovedregel ikke ha direkte betydning for din behandling på det nåværende tidspunkt, men de vil danne grunnlag for bedre behandlingstilbud for pasienter med tarmsykdommer som cøliaki i framtiden. Dette kan også komme deg til nytte. All informasjon av 
medisinsk relevans som fremkommer som ledd i forskningen, vil bli vurdert av prosjektleder og klinikerne som deltar i forskningen. Der det er klinisk grunn til det, vil du bli kontaktet for å drøfte funnene. Du kan også få tilgang til resultatet av prøver som er utført på ditt biologiske materiale ved å kontakte prosjektleder.

Mulige ulemper knyttet til glutenprovokasjon og undersøkelser er beskrevet under kapittel A.

\section{Frivillig deltakelse}

Det er frivillig å delta i studiene. Du kan når som helst og uten å oppgi noen grunn trekke ditt samtykke til å delta. Dette vil ikke få konsekvenser for din videre behandling fra sykehusets side. Dersom du ønsker å delta, undertegner du samtykkeerklæringen på siste side. Dersom du senere ønsker å trekke deg eller har spørsmål til studiene, kan du kontakte overlege, dr. med. Knut E. A. Lundin, Gastro undersøkelse. OUS Rikshospitalet, tlf. 230723 88, 23072400 el. 23070000.

Ytterligere informasjon om studiene finnes i kapittel $\boldsymbol{A}$ - utdypende forklaring av hva studiene innebærer.

Ytterligere informasjon om biobank, personvern og forsikring finnes i kapittel B Personvern, biobank, økonomi og forsikring.

\section{Samtykkeerklæring følger etter kapittel B.}




\section{Kapittel A- utdypende forklaring om deltakelse i forskning}

\section{Hvem blir forespurt om å delta i forskning påen}

Pasienter som er henvist til OUS, eller samarbeidende sykehus, til utredning og/eller behandling for tarmsykdommer inkludert, men ikke begrenset til, tynntarmsykdommen cøliaki og deres nære slektninger kan bli forespurt om å gi sitt samtykke til deltakelse i studiene. Det er også aktuelt å inkludere frivillige cøliakere eller andre personer, som ønsker å bidra til forskning.

\section{Bakgrunnsinformasjon om studiene}

Årsaken til cøliaki er bare delvis kjent. Hos pasienter med cøliaki skjer det en immunreaksjon mot gluten, et protein som finnes i hvete, spelt, rug og bygg. Så lenge pasientene spiser skadelige kornslag, gjør betennelsen at tarmtottene er borte, og opptaket av næring og vitaminer fra tarmen reduseres. Pasientene merker dette med magesmerter, urolig mage, mange har diaré, og de fleste føler tretthet. Noen pasienter med aktiv cøliaki opplever seg som friske, men det er da vanlig at de allikevel føler seg enda bedre når de starter med gluten fri kost. Når pasientene med cøliaki slutter å spise skadelige kornslag går betennelsen tilbake og tottene vokser ut igjen. Mange pasienter som reagerer på gluten eller annen mat gjør det uten de typiske cøliakiforandringene i tarmen. Man snakker da gjerne om "non-cøliakisk gluten sensitivitet". Gener er av betydning for utviklingen av sykdommene, men andre faktorer spiller også en viktig rolle. Vi ønsker å kartlegge videre hvilke gener som kan bidra til utvikling og forløp av cøliaki og hvordan gener kan samspille med immunsystemet eller andre faktorer. Økt forståelse av sykdomsmekanismene kan gi grunnlag for bedre oppfølging og behandling av pasienter med slike sykdommer.

I studiene er vi ofte interesserte i vevsprøver fra personer som ikke har cøliaki. Dette vil være personer som kommer til undersøkelse enten på grunn av andre, kjente sykdomstilstander, eller der man ønsker å utelukke sykdom. Slike personer er svært verdifulle for studiene fordi vi da sammenligner immunsystemet hos cøliakere med immunsystemet hos andre.

Noen ganske få pasienter med cøliaki utvikler komplikasjoner i form av forstadier til kreft eller kreft i tarmen eller lymfesystem. Vi vil arbeide med å utvikle metoder for å kunne påvise tidlige stadier av kreft, slik at behandling kan iverksettes så tidlig som mulig.

\section{Prøver fra blod, afvøring og vev}

Blodprøver vil bli tatt 5 ganger i løpet av studien. Den totale mengde blod vil tilsvare det som vanligvis blir tatt ved blodgiving til blodbanken (ca. $400 \mathrm{ml}$ ). Hvis det foreligger kjent blodmangel, eller hvis dette oppdages ved første blodprøve, vil man vurdere forsvarligheten av ytterligere blodtaking og evt. redusere på mengden blod som tas hvis blodmangelen er mild/moderat.

Det planlegges taking av avføringsprøver med tilrettelagt oppsamlingsutstyr. Vevsprøver tas ved gastroskopi.

Prøvene fra deg vil enten bli lagret i fryseboks eller vi vil straks prosessere dem videre. Vår laboratorieaktivitet favner nær sagt alle metoder innen moderne, bioteknologisk forskning. Dette innbefatter:

- Undersøkelse av celler og signalstoffer i vevsprøver, blod og serum

- Dyrkning av dine immunceller i reagensrør og undersøkelse på deres funksjon og 
reaksjonsmønster

- Undersøkelse av hvilke gener som er skrudd på i vevsprøver og i blodceller

- Isolering av enkelte gener hos den enkelte pasient og undersøkelse på hvilke varianter de har

- Undersøkelse av hele arvematerialet hos pasientene for å forstå samspillet mellom de enkelte genene

\section{Mulige ubehag/ulemper}

Deltakelse i studiene kan medføre ekstra ubehag og ulempe for deg. Du vil bli spurt om å spise mat som du kan reagere på. Dette er en vanlig prosedyre ved utredning av matvareintoleranse og cøliaki. Noen personer kan oppleve symptomer som kvalme, oppkast, slapphet og diare. Vi ønsker derfor kun å inkludere personer som ikke har en historie med sterk reaksjon på gluten. Som en ekstra sikkerhet vil den første dosen med gluten bli gitt på sykehus med mulighet for raskt tilsyn av lege i timene etter inntak.

Som ledd i denne studien vil du gjennomgå en gastroskopi. Dette er en undersøkelse du sannsynligvis kjenner godt fra før. Man fører da en slange med kamera på tuppen for å undersøke slimhinnen i tarmen, og via et rørsystem kan man også ta små vevsprøver. De fleste opplever denne undersøkelsen som noe ubehagelig da man under undersøkelsen vil kunne oppleve brekninger, luftsmerter i magen og noen vil også kunne få følelse av angst. Undersøkelsen er ufarlig da komplikasjonsraten er svært lav i trenede hender. Ved OUS Rikshospitalet er det personell med lang erfaring innen dette og det foreligger også tilbud om beroligende medisin før undersøkelsen.

Alle prosedyrene utføres av spesialtrenet personell som vil legge stor vekt på å minimalisere ubehaget for den enkelte deltager. Det blir ikke tatt prøver hvis man mistenker at dette kan gå utover pasientenes sikkerhet eller hvis pasienten er uvanlig besværet under prøvetakingen.

Man kan tenke seg at det i studien gjøres funn som har klinisk betydning for den enkelte pasient. Dette kan for eksempel innebære at man finner tegn til ondartet sykdom (kreft). Slike opplysninger vil uten unntak bli vurdert av prosjektleder etter at de er spilt inn fra forskerne i studien. Dagens vitenskapelige metoder innbefatter analyse på enkeltgener hos den enkelte pasient. Selv om vi planlegger all vår forskning slik at den ikke skal fange opp såkalte "sykdomsgener", kan man ikke helt garantere at dette kan skje. Vi har allerede etablert en beredskap for slike tilfeller. Vi har avtalt med spesialist i medisinsk genetikk, som vil rådgi prosjektleder og ta seg av informasjon til den enkelte pasient. Dette er i henhold til gjeldende regelverk og lovgivning.

\section{Ny informasjon som kan påvirke studiene}

Dersom ny informasjon blir tilgjengelig som kan påvirke din villighet til å delta i studiene, vil du bli orientert så raskt som mulig. 


\section{Kapittel B - Personvern, biobank, økonomi og forsikring}

\section{Hva skjer med prøvene og informasjonen om deg?}

\section{Kodenummer}

Prøvene tatt av deg og informasjonen som registreres om deg skal kun brukes slik som beskrevet i denne informasjonen. Prøvene blir merket med et kodenummer og vil bli behandlet uten navn og fødselsnummer eller andre direkte gjenkjennende opplysninger. Listen som knytter ditt navn til kodenummeret vil bli oppbevart separat. Det er kun autorisert, sentralt personell (leger eller annet personell med taushetsplikt) knyttet til forskningsprosjektene som har adgang til navnelisten og som kan finne tilbake til deg.

Det vil ikke være mulig å identifisere deg i resultatene av studiene når disse publiseres.

\section{Personvern}

Opplysninger som registreres om deg vil gjelde forhold som vi mener kan være av betydning for utvikling og forløp av din tarmsykdom. Dette vil også inkludere andre tilstander som av og til ses samtidig med tarmsykdommer. Vi vil registrere symptomer, blodprøvesvar, funn ved andre typer undersøkelser (for eksempel røntgenundersøkelser) og behandling som er gitt. Vi vil primært benytte opplysninger fra din journal ved OUS. Av og til vil det være nødvendig å innhente supplerende opplysninger av tilsvarende type fra journal hos fastlege eller annen helseinstitusjon.

I enkelte prosjekter kan det bli aktuelt å koble forskningsdata til andre registre. Slik kobling vil bare skje etter forutgående godkjenning av Datatilsynet og Regional etisk komité for medisinsk og helsefaglig forskningsetikk. Opplysninger fra aktuelle registre omfatter: eventuell kreftforekomst (Kreftregisteret), dødsårsak (Dødsårsaksregisteret), medisinske forhold rundt fødsel (Medisinsk fødselsregister), medikamenter (Reseptregisteret) og bosted (Folkeregisteret). Alle data lagres i henhold til prosedyrer som er godkjent av Personvernombudet.

Oslo Universitetssykehus ved administrerende direktør er databehandlingsansvarlig.

\section{Biobank}

Prøver fra blod, andre vevsvæsker og vev og informasjonen utledet av dette materialet vil bli lagret i en forskningsbiobank ved OUS. Hvis du sier ja til å delta i studiene, gir du også samtykke til at det biologiske materialet og analyseresultater inngår i biobanken. Biobanken er tilrådd av Regional etisk komité for medisinsk og helsefaglig forskningsetikk, og godkjent av Helsedirektoratet. Biobanken drives i tråd med nasjonale og lokale retningslinjer. Overlege, dr. med. Knut E. A. Lundin er ansvarshavende for forskningsbiobanken. Biobanken og helseopplysningene planlegges å lagres i første omgang til 2028. Det kan bli aktuelt å søke om forlenget oppbevaring, og vi ber derfor om å kunne komme tilbake for å be om slik forlengelse. Når forskningsprosjektet avsluttes, vil materiale og opplysninger bli destruert og slettet etter interne retningslinjer.

Utlevering av materiale og opplysninger til andre

Hvis du sier ja til å delta i studiene, gir du også ditt samtykke til at prøver og avidentifiserte 
opplysninger utleveres til forskningsgrupper vi samarbeider med. Vi samarbeider i størst utstrekning med forskningsgrupper innen EU, men samarbeidet kan også gjelde land med lover som ikke tilfredsstiller europeisk personvernlovgivning.

\section{Rett til innsyn og sletting av opplysninger om deg og sletting av prøver}

Hvis du sier ja til å delta i studiene, har du rett til å få innsyn i hvilke opplysninger som er registrert om deg. Du har videre rett til å få korrigert eventuelle feil i de opplysningene vi har registrert. Dersom du trekker deg fra studiene, kan du kreve å få slettet innsamlede prøver og opplysninger. Opplysninger som allerede er publisert kan imidlertid ikke slettes fra eventuelle publikasjoner. Det samme gjelder gensekvenser, cellelinjer eller annet biologisk materiale som er laget på basis av de prøvene du har avgitt. Eiendomsretten til disse bearbeidete produktene vil tilfalle forskerne i prosjektet, etter de regler som er gjeldende innenfor OUS og Universitet i Oslo. Det er et uttrykt mål at eventuelle oppfinnelser innen medisinsk vitenskap skal patenteres. Dette fordi de da kan kommersialiseres og bidra til nye behandlingsmåter utviklet av legemiddelindustri. Eiendomsretten til slik oppfinnelser tilfaller oppfinnerne/forskerne, og affiseres ikke av at du trekker din individuelle godkjenning tilbake. All vitenskapelig virksomhet i prosjektet kan selvsagt bli gjenstand for offentlig ettersyn.

\section{Sensitive opplysninger}

Alle forhold rundt en pasients helse er sensitive opplysninger. Håndtering av slike opplysninger er vel regulert av lovverket og interne retningslinjer.

\section{Økonomi}

Prosjektet og biobanken er finansiert gjennom offentlige forskningsmidler. Slike midler tilføres forskningsgruppen fra Universitetet i Oslo, fra Helse Sør-Øst, fra EUs forskningsprogram, fra National Institute of Health, fra stiftelsen Helse og Rehabilitering, fra forskningsstiftelsen Inven2 og fra en rekke andre finansieringskilder.

\section{Forsikring}

Du har vanlige pasientrettigheter som ledd i din kontakt med helseinstitusjonen og eventuell søknad til Norsk pasientskadeerstatning kan sendes på vanlig måte. Det er ingen spesiell forsikring knyttet til prosjektene.

\section{Informasjon om utfallet av studiene}

Deltakerne har rett til å få informasjon om resultatene av studiene som utføres. I hovedsak vil resultatene bli tilgjengelige som publikasjoner i internasjonale vitenskapelige tidsskrift. 


\section{Samtykke til deltakelse i studien "Mekanismene for cøliaki - delprosjekt 14 dager provokasjon med gluten"}

Navnelapp eller navn med blokkbokstaver og fødselsdato:

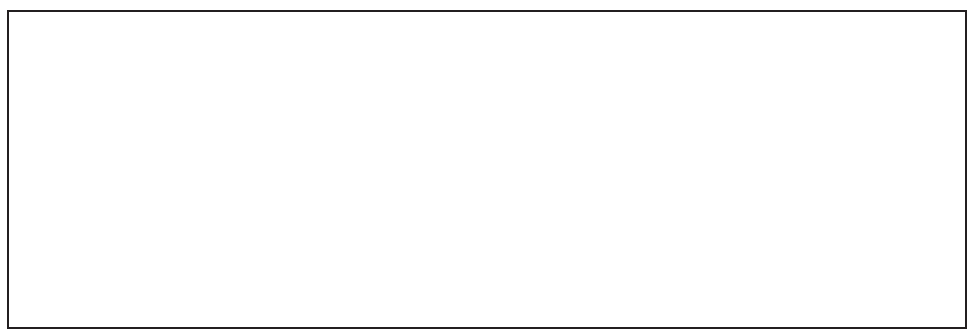

Jeg er villig til å delta i studiene "Mekanismene for cøliaki".

(Signert av prosjektdeltaker, dato)

Stedfortredende samtykke når berettiget, enten i tillegg til personen selv eller istedenfor

(Signert av nærstående, dato)

Jeg bekrefter å ha gitt informasjon om studiene

(Signert, medlem av prosjektledelsen, dato) 


\title{
Forespørsel om deltakelse i forskningsprosjektet
}

\author{
Delstudie til "Glutenprovokasjon ved coliaki og glutensensitivitet uten coliaki"
}

\section{"Gluten-og FODMAP-provokasjon av ikke-coliakisk glutensensitivitet”}

\section{Bakgrunn og hensikt}

Dette er et spørsmål til deg om å delta i en forskningsstudie for å undersøke effekten av gluten og andre kostholdsfaktorer ved glutensensitivitet uten cøliaki. Leger og forskere ved Oslo Universitetssykehus (OUS) arbeider hele tiden for å forbedre forståelsen av årsaken til tarmsykdommer og for å forbedre diagnostikk og behandling av slike tilstander. Resultatene av forskningen kan gi oss verdifull kunnskap og forståelse av mekanismer som kan ha betydning for framtidig oppfølging og behandling av pasientene.

\section{Studiens forløp}

I denne studien ønsker vi å undersøke i hvilken grad det er gluten eller såkalte kortkjedete karbohydrater (FODMAP $=$ Fermentable Oligo- Di- Monosaccharides And Polyols) som er årsaken til plager hos pasienter med mistenkt glutensensitivitet uten cøliaki. Du vil bli tilfeldig valgt ut til å spise en müslibar som inneholder enten gluten, FODMAP eller narremiddel (placebo) i 7 dager - en såkalt matvareprovokasjon. Verken du eller forskeren vet hvilken type du får. Dette skjer tre ganger fordi hver deltaker skal spise gluten i en uke, FODMAP i en uke og placebo i en uke. Vi ønsker å undersøke plagene som oppstår ved inntak av de ulike müslibarene. Du vil derfor bli bedt om å fylle ut spørreskjemaer som handler om blant annet mage- og tarmplager, livskvalitet og konsentrasjonsevne ved hver av de tre provokasjonene. Mellom hver provokasjon får du omtrent en ukes pause før neste provokasjon. Bortsett fra müslibaren skal du spise ditt vanlige glutenfrie kosthold. Vi ønsker at du tar en avføringsprøve før du starter og ved slutten av hver provokasjonsperiode, i alt seks prøver. Du vil få instruksjon og nødvendig utstyr til å ta disse hjemme.

Før du starter får du grundig informasjon i samtale med studielegen og klinisk ernæringsfysiolog. Her vil vi også gjøre en gastroskopiundersøkelse og ta vevsprøver fra tynntarmen. Det vil bli tatt blodprøver ved første konsultasjon, og deretter på første dag av hver provokasjonsuke.

Alle prosedyrer blir utført på OUS Rikshospitalet av spesialtrenet personell. Alle deltagere får informasjon om timeplanen i studien, og det er selvsagt frivillig å delta. Man kan også trekke seg mens studien pågår, uten å oppgi grunn, men studielegene vil bistå med medisinsk hjelp og råd.

\section{Hva innebærer deltakelse i studien?}

I forbindelse med dette prosjektet er det nødvendig å ta prøver av blod, vevsprøver og avføring. Den aktuelle studien er nært knyttet til vår øvrige cøliakiforskning, og alt biologisk materiale fra denne studien kan komme til nytte i våre øvrige prosjekter. Vi spør deg derfor om du vil gi tillatelse til:

- undersøker celler og signalstoffer i vevsprøver, blod og serum

- at deler av prøvene som blir til overs kan oppbevares til senere bruk i forskning på tarmsykdommer

- å ta ekstra blodprøver til studier av arvestoff (gener) og andre komponenter av mulig betydning for utvikling av tarmsykdom

- å fylle ut spørreskjemaer for å kartlegge symptomer før, under og etter matvareprovokasjon 


\section{Mulige fordeler og ulemper}

Resultatene av din individuelle provokasjonsperiode vil kunne gi deg direkte informasjon om din tilstand slik at du får tilpasset medisinsk behandling og kostholdsveiledning. Forskningsresultatene vil danne grunnlag for bedre utredning og behandlingstilbud for pasienter mistenkt glutensensitivitet uten cøliaki i nær framtid. All informasjon av medisinsk relevans som fremkommer som ledd i forskningen, vil bli vurdert av prosjektleder og klinikerne som deltar i forskningen. Der det er klinisk grunn til det, vil du bli kontaktet for å drøfte funnene. Du kan også få tilgang til resultatet av prøver som er utført på ditt biologiske materiale ved å kontakte prosjektleder.

\section{Hva skjer med prøvene og informasjonen om deg?}

Prøvene tatt av deg og informasjonen som registreres om deg skal kun brukes slik som beskrevet i hensikten med studien. Alle opplysningene og prøvene vil bli behandlet uten navn og fødselsnummer eller andre direkte gjenkjennende opplysninger. En kode knytter deg til dine opplysninger og prøver gjennom en navneliste.

Det er kun autorisert personell knyttet til prosjektet som har adgang til navnelisten og som kan finne tilbake til deg. Det vil ikke være mulig å identifisere deg i resultatene av studien når disse publiseres.

\section{Frivillig deltakelse}

Det er frivillig å delta i studiene. Du kan når som helst og uten å oppgi noen grunn trekke ditt samtykke til å delta. Dette vil ikke få konsekvenser for din videre behandling fra sykehusets side. Dersom du ønsker å delta, undertegner du samtykkeerklæringen på siste side. Dersom du senere ønsker å trekke deg eller har spørsmål til studiene, kan du kontakte overlege, dr. med. Knut E. A. Lundin, Gastroundersøkelse. OUS Rikshospitalet, tlf. 230723 88, 23072400 el. 23070000.

Ytterligere informasjon om studien finnes i kapittel $\boldsymbol{A}$-utdypende forklaring av hva studien inneborer.

Ytterligere informasjon om biobank, personvern og forsikring finnes i kapittel B - Personvern, biobank, økonomi og forsikring.

\section{Samtykkeerklæring følger etter kapittel B.}




\title{
Kapittel A- utdypende forklaring av hva studien innebarer
}

\author{
Hvem blir forespurt om å delta i forskningsstudien? \\ Pasienter som er henvist til OUS, eller samarbeidende sykehus, til utredning og/eller behandling for \\ glutensensitivitet uten cøliaki kan bli forespurt om å gi sitt samtykke til deltakelse i studien. \\ Invitasjonen går også ut til publikum der kriteriet for å delta er at cøliaki er utelukket ved gastroskopi \\ med tynntarmsbiopsi. Hveteallergi skal også være utelukket. Personer som kan delta skal ha oppnådd \\ symptomlindring på konsekvent glutenfri kost.
}

\section{Bakgrunnsinformasjon om studien}

Et ukjent antall i befolkningen har ikke cøliaki, men tåler likevel ikke gluten i kosten. Tilstanden er definert som en klinisk tilstand der gluten i kosten gir symptomer som ligner på cøliaki, men der man ikke finner tegn til cøliaki verken med blodprøver eller etter gastroskopi med biopsi.

Årsakssammenhengen er uklar og man har ingen god definisjon på sykdommen. Tilstanden har vært kjent i flere år, men utbredelsen har økt de siste få årene. Mange kommer til spesialisthelsetjenesten for å få hjelp, og selv der er utredningen er utfordrende. Det er fortsatt usikkert om det er gluten som gir symptomer. Noe forskning peker mot de såkalte FODMAP som en forklaring på plagene. Målet med studien er å øke kunnskapen om glutensensitivitet uten cøliaki ved å undersøke betydningen av gluten og FODMAP i kostholdet. Vi ønsker også å forbedre utredningsmetoden.

\section{Prøver fra vev og vevsvasker, blod og avføring}

Ved gastroskopi vil det bli tatt vevsprøver fra tynntarm. Disse vil bli brukt til å vurdere betennelsesmarkører i tynntarmen. Det vil bli tatt blodprøver ved fire anledninger i løpet av studien. Du vil også bli bedt om å ta avføringsprøver seks ganger. Dette tas for å undersøke hvordan immunsystemet og tarmens bakterieflora reagerer på inntaket av det du blir bedt om å spise.

\section{Mulige fordeler}

En åpenbar fordel for deg som deltar er at du får en grundig utredning av din tilstand som vil gi svar på hva som vil være den beste behandlingen for deg. Som deltaker er det viktig at du rapporterer hvordan du har det så sant som mulig i spørreskjemaene. Det er også viktig at du melder fra dersom du ikke får til å følge studieplanen slik som planlagt. Dersom du skulle velge ikke å delta i studien vil du få tilbud om standard behandling.

\section{Mulige ubehag/ulemper}

Deltakelse i studien kan medføre ekstra ubehag og ulempe for deg i deler av forløpet. I dette tilfellet ønsker vi at du skal spise mat (gluten) som du kan reagere på, dette er en vanlig prosedyre ved utredning av matvareintoleranse. Det kan gi ubehag, men det er ingen risiko forbundet med å delta. Dersom gluten gir alvorlige reaksjoner, skal du ikke delta.

Som ledd i denne studien vil du gjennomgå en gastroskopi. Dette er en undersøkelse du sannsynligvis kjenner godt fra før. Man fører da en slange med kamera på tuppen for å undersøke slimhinnen i tarmen, og via et rørsystem kan man også ta små vevsprøver. De fleste opplever denne undersøkelsen som noe ubehagelig da man under undersøkelsen vil kunne oppleve brekninger, luftsmerter i magen og noen vil også kunne få følelse av angst. Undersøkelsen er ufarlig da komplikasjonsraten og blødningsrisikoen er svært lav i trenede hender. Ved OUS Rikshospitalet er det personell med lang erfaring innen dette og det foreligger også tilbud om beroligende medisin før undersøkelsen. Alle prosedyrene utføres av spesialtrenet personell som vil legge stor vekt på å minimalisere ubehaget for den enkelte deltager. Det blir ikke tatt prøver hvis man mistenker at dette kan gå utover pasientenes sikkerhet eller hvis pasienten er uvanlig besværet under prøvetakingen. 
Man kan tenke seg at det i studien gjøres funn som har klinisk betydning for den enkelte pasient. Dette kan for eksempel innebære at man finner tegn til ondartet sykdom (kreft). Slike opplysninger vil uten unntak bli vurdert av prosjektleder etter at de er spilt inn fra forskerne i studien. Dagens vitenskapelige metoder innbefatter analyse på enkeltgener hos den enkelte pasient. Selv om vi planlegger all vår forskning slik at den ikke skal fange opp såkalte "sykdomsgener", kan man ikke helt garantere at dette kan skje. Vi har allerede etablert en beredskap for slike tilfeller. Vi har avtalt med spesialist i medisinsk genetikk, som vil rådgi prosjektleder og ta seg av informasjon til den enkelte pasient. Dette er i henhold til gjeldende regelverk og lovgivning.

\section{Ny informasjon som kan påvirke studiene}

Dersom ny informasjon blir tilgjengelig som kan påvirke din villighet til å delta i studiene, vil du bli orientert så raskt som mulig.

\section{Kapittel B - Personvern, biobank, økonomi og forsikring}

\section{Hva skjer med prøvene og informasjonen om deg?}

\section{Kodenummer}

Prøvene tatt av deg og informasjonen som registreres om deg skal kun brukes slik som beskrevet $\mathrm{i}$ denne informasjonen. Prøvene blir merket med et kodenummer og vil bli behandlet uten navn og fødselsnummer eller andre direkte gjenkjennende opplysninger. Listen som knytter ditt navn til kodenummeret vil bli oppbevart separat. Det er kun autorisert, sentralt personell (leger eller annet personell med taushetsplikt) knyttet til forskningsprosjektene som har adgang til navnelisten og som kan finne tilbake til deg.

Det vil ikke være mulig å identifisere deg i resultatene av studiene når disse publiseres.

\section{Personvern}

Opplysninger som registreres om deg vil gjelde forhold som vi mener kan være av betydning for utvikling og forløp av din tarmsykdom. Dette vil også inkludere andre tilstander som av og til ses samtidig med tarmsykdommer. Vi vil registrere symptomer, blodprøvesvar, funn ved andre typer undersøkelser (for eksempel røntgenundersøkelser) og behandling som er gitt. Vi vil primært benytte opplysninger fra din journal ved OUS. Av og til vil det være nødvendig å innhente supplerende opplysninger av tilsvarende type fra journal hos fastlege eller annen helseinstitusjon.

I enkelte prosjekter kan det bli aktuelt å koble forskningsdata til andre registre. Slik kobling vil bare skje etter forutgående godkjenning av Datatilsynet og Regional etisk komité for medisinsk og helsefaglig forskningsetikk. Opplysninger fra aktuelle registre omfatter: eventuell kreftforekomst (Kreftregisteret), dødsårsak (Dødsårsaksregisteret), medisinske forhold rundt fødsel (Medisinsk fødselsregister), medikamenter (Reseptregisteret) og bosted (Folkeregisteret). Alle data lagres i henhold til prosedyrer som er godkjent av Personvernombudet.

Oslo Universitetssykehus ved administrerende direktør er databehandlingsansvarlig.

\section{Biobank}

Prøver fra blod, andre vevsvæsker og vev og informasjonen utledet av dette materialet vil bli lagret $\mathrm{i}$ en forskningsbiobank ved OUS. Hvis du sier ja til å delta i studiene, gir du også samtykke til at det biologiske materialet og analyseresultater inngår i biobanken. Biobanken er tilrådd av Regional etisk 
komité for medisinsk og helsefaglig forskningsetikk, og godkjent av Helsedirektoratet. Biobanken drives i tråd med nasjonale og lokale retningslinjer. Overlege, dr. med. Knut E. A. Lundin er ansvarshavende for forskningsbiobanken. Biobanken og helseopplysningene planlegges å lagres $\mathrm{i}$ første omgang til 2028. Det kan bli aktuelt å søke om forlenget oppbevaring, og vi ber derfor om å kunne komme tilbake for å be om slik forlengelse. Når forskningsprosjektet avsluttes, vil materiale og opplysninger bli destruert og slettet etter interne retningslinjer.

\section{Utlevering av materiale og opplysninger til andre}

Hvis du sier ja til å delta i studiene, gir du også ditt samtykke til at prøver og avidentifiserte opplysninger utleveres til forskningsgrupper vi samarbeider med. Vi samarbeider i størst utstrekning med forskningsgrupper innen EU, men samarbeidet kan også gjelde land med lover som ikke tilfredsstiller europeisk personvernlovgivning.

\section{Rett til innsyn og sletting av opplysninger om deg og sletting av prøver}

Hvis du sier ja til å delta i studiene, har du rett til å få innsyn i hvilke opplysninger som er registrert om deg. Du har videre rett til å få korrigert eventuelle feil i de opplysningene vi har registrert. Dersom du trekker deg fra studiene, kan du kreve å få slettet innsamlede prøver og opplysninger. Opplysninger som allerede er publisert kan imidlertid ikke slettes fra eventuelle publikasjoner. Det samme gjelder gensekvenser, cellelinjer eller annet biologisk materiale som er laget på basis av de prøvene du har avgitt. Eiendomsretten til disse bearbeidete produktene vil tilfalle forskerne i prosjektet, etter de regler som er gjeldende innenfor OUS og Universitet i Oslo. Det er et uttrykt mål at eventuelle oppfinnelser innen medisinsk vitenskap skal patenteres. Dette fordi de da kan kommersialiseres og bidra til nye behandlingsmåter utviklet av legemiddelindustri. Eiendomsretten til slik oppfinnelser tilfaller oppfinnerne/forskerne, og affiseres ikke av at du trekker din individuelle godkjenning tilbake. All vitenskapelig virksomhet i prosjektet kan selvsagt bli gjenstand for offentlig ettersyn.

\section{Sensitive opplysninger}

Alle forhold rundt en pasients helse er sensitive opplysninger. Håndtering av slike opplysninger er vel regulert av lovverket og interne retningslinjer.

\section{Økonomi}

Prosjektet og biobanken er finansiert gjennom offentlige forskningsmidler. Slike midler tilføres forskningsgruppen fra Universitetet i Oslo, fra Helse Sør-Øst, fra EUs forskningsprogram, fra National Institute of Health, fra stiftelsen Helse og Rehabilitering, fra forskningsstiftelsen Inven2 og fra en rekke andre finansieringskilder.

\section{Forsikring}

Du har vanlige pasientrettigheter som ledd i din kontakt med helseinstitusjonen og eventuell søknad til Norsk pasientskadeerstatning kan sendes på vanlig måte. Det er ingen spesiell forsikring knyttet til prosjektene.

\section{Informasjon om utfallet av studiene}

Deltakerne har rett til å få informasjon om resultatene av studiene som utføres. I hovedsak vil resultatene bli tilgjengelige som publikasjoner i internasjonale vitenskapelige tidsskrift. 


\section{Samtykke til deltakelse i studien}

\section{"Gluten-og FODMAP-provokasjon av ikke-coliakisk glutensensitivitet"}

Del av: "Glutenprovokasjon ved coliaki og glutensensitivitet uten coliaki»

Jeg er villig til å delta i studien Gluten- og FODMAP-provokasjon ved glutensensitivitet uten cøliaki

(Signert av prosjektdeltaker, dato)

Stedfortredende samtykke når berettiget, enten i tillegg til personen selv eller istedenfor

(Signert av nærstående, dato)

Jeg bekrefter å ha gitt informasjon om studien

(Signert, rolle i studien, dato) 
1. De siste 6 månedene har jeg fulgt en glutenfri diett:

Hele tiden

Mesteparten av tiden

Halvparten av tiden

Litt av tiden

Ikke i det hele tatt

2. Drikke du øl? $\quad \square$ Ja $\quad \square$ Nei $\quad \square$ Av og til

Hvis Ja eller Av og til, hvilke merker velger du?
3. Spiser du
a) Vanlig brød?
$\square \mathrm{Ja}$
$\square$ Nei
Av og til
b) Vanlig havre?
$\square \mathrm{Ja}$
$\square$ Nei
Av og til
c) Spelt?
$\square \mathrm{Ja}$
$\square$ Nei
Av og til

4. Dersom du har fått i deg gluten, opplever du symptomer?

$\square$ Alltid $\square$ Ofte $\quad \square$ Avogtil $\square$ Sjelden $\square$ Aldri

5. Hvor ofte får du symptomer hvis du får i deg selv små mengder gluten, for eksempel brødsmuler?
$\square$ Alltid
$\square$ Ofte
$\square$ Av og til
$\square$ Sjelden
Aldri

6. Hvor mange ganger $\underline{i \text { året }}$ skjer det at du smaker på glutenholdig mat?
Aldri
$\square$ 1-2 ganger
3-5 ganger
6-10 ganger
Mer enn 10 ganger

8. Hender det at du spiser gluten uten at du er klar over det (for eksempel glemmer at du ikke kan spise visse matvarer)?
Alltid
$\square$ Ofte
$\square$ Av og til
$\square$ Sjelden
Aldri

9. Dersom du er usikker på om en matvare inneholder gluten, hender det at du spiser den likevel?

$\square$ Alltid $\square$ Ofte $\square$ Av og til $\square$ Sjelden $\square$ Aldri

10. Dersom du er på ferie, hender det at du avviker fra den glutenfrie dietten?

$\square$ Alltid $\square$ Ofte $\square$ Avogtil $\square$ Sjelden $\square$ Aldri 
11. Er mat på vei til jobb, skole, reise ("mat i farta"), situasjoner hvor du lettere utsetter deg for glutenholdig mat?

$\square$ Alltid $\square$ Ofte $\quad \square$ Av og til $\square$ Sjelden $\square$ Aldri

12. Hvor ofte hender det at du spiser glutenholdig mat for å være høflig eller av hensyn til andre (sosiale sammenkomster)?
Alltid
$\square$ Ofte
Av og til
Sjelden
Aldri

13. Hvor ofte hender det at du spiser gluten for ikke å være "annerledes" og for å unngå spørsmål i sosiale sammenhenger?
Alltid
$\square$ Ofte
Av og til
Sjelden
Aldri

Andre situasjoner (f.eks pga religiøse situasjoner):

14. Forstår du ingredienslister på produkter?
Alltid

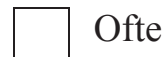
$\square$ Av og til
$\square$ Sjelden
$\square$ Aldri

15. Hvor ofte sjekker du ingredienslister på produkter du tidligere ikke har brukt?
$\square$ Alltid

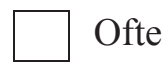
Av og til
$\square$ Sjelden
$\square$ Aldri

16. Klarer du å unngå gluten i uforutsette situasjoner?
$\square$ Alltid

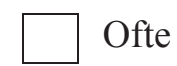
$\square$ Av og til
$\square$ Sjelden

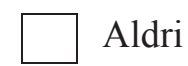

17. Hender det at du avviker fra dietten når det er krevende å finne glutenfrie alternativer?
Alltid

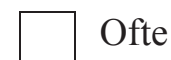
$\square$ Av og til
$\square$ Sjelden
$\square$ Aldri

18. Etter min mening er det en utfordring å finne glutenfrie alternativer i hverdagen:
$\square$ Enig
$\square$ Delvis enig
$\square$ Usikker
$\square$ Delvis uenig
Uenig

19. Jeg føler jeg har god nok kunnskap til å mestre den glutenfrie dietten:
$\square$ Enig

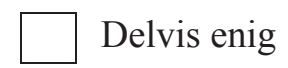
$\square$ Usikker
$\square$ Delvis uenig
Uenig

20. I hvilken grad vil du si den glutenfrie kosten er viktig for helsen din?

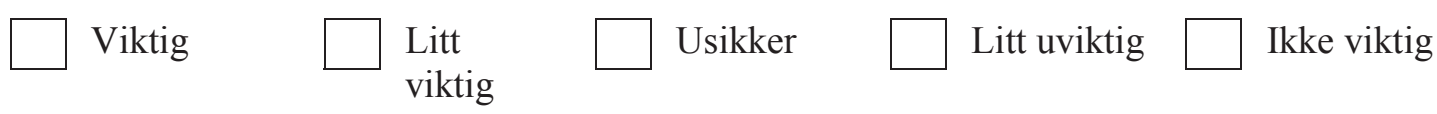

21. Hvordan vurderer du helsen din i forhold til ikke-glutensensitive?

$\square$ Mye bedre $\square$ Litt bedre $\square$ Like god $\square$ Litt dårligere $\square$ Mye dårligere 


\section{Test for etterlevelse av glutenfri kost ${ }^{1}$}

Sett ring rundt svaralternativet som passer best:

\begin{tabular}{|c|c|c|c|c|c|}
\hline Spørsmål & 1 & 2 & 3 & 4 & 5 \\
\hline $\begin{array}{l}\text { 1. Har du vært plaget med } \\
\text { manglende overskudd i løpet } \\
\text { av de siste } 4 \text { ukene? }\end{array}$ & $\begin{array}{l}\text { Ikke i det } \\
\text { hele tatt }\end{array}$ & Litt av tiden & $\begin{array}{l}\text { En del av } \\
\text { tiden }\end{array}$ & $\begin{array}{l}\text { Mesteparten } \\
\text { av tiden }\end{array}$ & Hele tiden \\
\hline $\begin{array}{l}\text { 2. Har du vært plaget med } \\
\text { hodepine i løpet av de siste } 4 \\
\text { ukene? }\end{array}$ & $\begin{array}{l}\text { Ikke i det } \\
\text { hele tatt }\end{array}$ & Litt av tiden & $\begin{array}{l}\text { En del av } \\
\text { tiden }\end{array}$ & $\begin{array}{l}\text { Mesteparten } \\
\text { av tiden }\end{array}$ & Hele tiden \\
\hline $\begin{array}{l}\text { 3. Det er mulig for meg å spise } \\
\text { glutenfritt når jeg spiser borte }\end{array}$ & Sterkt enig & Noe enig & $\begin{array}{l}\text { Verken enig } \\
\text { eller uenig }\end{array}$ & Noe uenig & Sterkt uenig \\
\hline $\begin{array}{l}\text { 4. Før jeg gjør noe vurderer jeg } \\
\text { nøye konsekvensene }\end{array}$ & Sterkt enig & Noe enig & $\begin{array}{l}\text { Verken enig } \\
\text { eller uenig }\end{array}$ & Noe uenig & Sterkt uenig \\
\hline $\begin{array}{l}\text { 5. Jeg anser ikke meg selv som } \\
\text { mislykket }\end{array}$ & Sterkt enig & Noe enig & $\begin{array}{l}\text { Verken enig } \\
\text { eller uenig }\end{array}$ & Noe uenig & Sterkt uenig \\
\hline $\begin{array}{l}\text { 6. Hvor viktig er uhell med } \\
\text { gluteninntak for helsen din? }\end{array}$ & Veldig viktig & $\begin{array}{l}\text { Ganske } \\
\text { viktig }\end{array}$ & $\begin{array}{l}\text { Nøytral/ } \\
\text { usikker }\end{array}$ & Litt viktig & $\begin{array}{l}\text { Ikke viktig i } \\
\text { det hele tatt }\end{array}$ \\
\hline $\begin{array}{l}\text { 7. Hvor mange ganger har du } \\
\text { spist glutenholdig mat med } \\
\text { vilje i løpet av de siste } 4 \\
\text { ukene? }\end{array}$ & 0 (aldri) & 1-2 ganger & 3-5 ganger & 6-10 ganger & $\begin{array}{l}\text { Mer enn } 10 \\
\text { ganger }\end{array}$ \\
\hline
\end{tabular}

\footnotetext{
${ }^{1}$ Celiac Dietary Adherence Test (CDAT) The Celiac Center, Beth Israel Deaconess Medical Center, Boston, MA. Leffler D, Dennis M, Edwards George J, Jamma S, Magge S, Cook EF, Schuppan D, Kelly CP. A Simple Validated Gluten Free Diet Adherence Survey for Adults with Celiac Disease. Clinical Gastroenterology and Hepatology. 2009 May;7(5):530-6, 536.e1-2. Epub 2009 Jan 11.
} 
THE GASTROINTESTINAL SYMPTOM RATING SCALE (GSRS) IRRITABLE BOWEL SYNDROME (IBS)-VERSJON

\section{Les dette først:}

Undersøkelsen inneholder spørsmål om hvordan du har følt deg og hvordan du har hatt det DE 7 SISTE DAGER. Sett kryss (X) ved det alternativet som passer best på deg og din situasjon.

Dato:

1. Har du i løpet av den siste uken vært plaget av MAGESMERTER?

$\square \quad$ Ingen plager i det hele tatt

$\square \quad$ Ubetydelige plager

$\square \quad$ Milde plager

$\square$ Moderate plager

$\square \quad$ Ganske alvorlige plager

$\square \quad$ Alvorlige plager

$\square \quad$ Meget alvorlige plager

2. Har du i løpet av den siste uken vært plaget av SMERTER ELLER UBEHAG I MAGEN SOM GIR SEG NÅR DU HAR HATT AVFØRING?

$\square \quad$ Ingen plager i det hele tatt

$\square \quad$ Ubetydelige plager

$\square \quad$ Milde plager

$\square \quad$ Moderate plager

$\square \quad$ Ganske alvorlige plager

$\square \quad$ Alvorlige plager

$\square \quad$ Meget alvorlige plager 
3. Har du i løpet av den siste uken vært plaget av OPPBLÅSTHET?

$\square \quad$ Ingen plager i det hele tatt

$\square \quad$ Ubetydelige plager

$\square \quad$ Milde plager

$\square$ Moderate plager

$\square$ Ganske alvorlige plager

$\square \quad$ Alvorlige plager

$\square \quad$ Meget alvorlige plager

4. Har du i løpet av den siste uken vært plaget av LUFTAVGANG?

$\square \quad$ Ingen plager i det hele tatt

$\square \quad$ Ubetydelige plager

$\square$ Milde plager

$\square \quad$ Moderate plager

$\square$ Ganske alvorlige plager

$\square \quad$ Alvorlige plager

$\square \quad$ Meget alvorlige plager

5. Har du i løpet av den siste uken vært plaget av FORSTOPPELSE (problemer med å tømme tarmen)?

$\square \quad$ Ingen plager i det hele tatt

$\square \quad$ Ubetydelige plager

$\square$ Milde plager

$\square \quad$ Moderate plager

$\square \quad$ Ganske alvorlige plager

$\square \quad$ Alvorlige plager

$\square \quad$ Meget alvorlige plager 
6. Har du i løpet av den siste uken vært plaget av DIARÉ (hyppig avføring)?

$\square \quad$ Ingen plager i det hele tatt

$\square \quad$ Ubetydelige plager

$\square \quad$ Milde plager

$\square \quad$ Moderate plager

$\square \quad$ Ganske alvorlige plager

$\square \quad$ Alvorlige plager

$\square \quad$ Meget alvorlige plager

7. Har du i løpet av den siste uken vært plaget av LØS AVFØRING?

$\square \quad$ Ingen plager i det hele tatt

$\square \quad$ Ubetydelige plager

$\square \quad$ Milde plager

$\square$ Moderate plager

$\square \quad$ Ganske alvorlige plager

$\square \quad$ Alvorlige plager

$\square \quad$ Meget alvorlige plager

8. Har du i løpet av den siste uken vært plaget av HARD AVFØRING?

$\square \quad$ Ingen plager i det hele tatt

$\square \quad$ Ubetydelige plager

$\square \quad$ Milde plager

$\square \quad$ Moderate plager

$\square \quad$ Ganske alvorlige plager

$\square \quad$ Alvorlige plager

$\square \quad$ Meget alvorlige plager 
9. Har du i løpet av den siste uken vært plaget av TVINGENDE AVFØRINGSBEHOV (plutselig behov for å gå på toalettet for å tømme tarmen)?

$\square \quad$ Ingen plager i det hele tatt

$\square \quad$ Ubetydelige plager

$\square \quad$ Milde plager

$\square \quad$ Moderate plager

$\square \quad$ Ganske alvorlige plager

$\square$ Alvorlige plager

$\square \quad$ Meget alvorlige plager

10. Har du i løpet av den siste uken vært plaget av en FØLELSE AV UFULLSTENDIG TØMMING AV TARMEN ETTER AVFØRING?

$\square \quad$ Ingen plager i det hele tatt

$\square \quad$ Ubetydelige plager

$\square \quad$ Milde plager

$\square \quad$ Moderate plager

$\square$ Ganske alvorlige plager

$\square \quad$ Alvorlige plager

$\square \quad$ Meget alvorlige plager

11. Har du i løpet av den siste uken vært plaget av at du FØLER DEG METT LIKE ETTER AT DU HAR BEGYNT PÅ ET MÅLTID?

$\square \quad$ Ingen plager i det hele tatt

$\square \quad$ Ubetydelige plager

$\square \quad$ Milde plager

$\square \quad$ Moderate plager

$\square \quad$ Ganske alvorlige plager

$\square \quad$ Alvorlige plager

$\square \quad$ Meget alvorlige plager 
12. Har du i løpet av den siste uken vært plaget av at du FØLER DEG METT SELV LENGE ETTER AT DU ER FERDIG MED Å SPISE?

$\square \quad$ Ingen plager i det hele tatt

$\square \quad$ Ubetydelige plager

$\square \quad$ Milde plager

$\square$ Moderate plager

$\square$ Ganske alvorlige plager

$\square \quad$ Alvorlige plager

$\square \quad$ Meget alvorlige plager

13. Har du i løpet av den siste uken vært plaget av at MAGEN ER SYNLIG OPPBLÅST?

$\square \quad$ Ingen plager i det hele tatt

$\square \quad$ Ubetydelige plager

$\square$ Milde plager

$\square$ Moderate plager

$\square \quad$ Ganske alvorlige plager

$\square \quad$ Alvorlige plager

$\square \quad$ Meget alvorlige plager

KONTROLLER AT ALLE SPØRSMÅLENE ER BESVART!

TAKK FOR DIN MEDVIRKNING. 


\begin{tabular}{|c|c|c|c|c|c|}
\hline Spørsmål & 1 & 2 & 3 & 4 & 5 \\
\hline $\begin{array}{l}\text { 1. Har du vært plaget med smerte eller } \\
\text { ubehag i øvre eller sentrale del av magen i } \\
\text { løpet av de siste } 4 \text { ukene? }\end{array}$ & $\begin{array}{l}\text { Ikke i det } \\
\text { hele tatt }\end{array}$ & Litt av tiden & $\begin{array}{l}\text { En del av } \\
\text { tiden }\end{array}$ & $\begin{array}{l}\text { Mesteparten } \\
\text { av tiden }\end{array}$ & Hele tiden \\
\hline $\begin{array}{l}\text { 2. Har du vært plaget med kvalme i løpet av } \\
\text { de siste } 4 \text { ukene? }\end{array}$ & $\begin{array}{l}\text { Ikke i det } \\
\text { hele tatt }\end{array}$ & Litt av tiden & $\begin{array}{l}\text { En del av } \\
\text { tiden }\end{array}$ & $\begin{array}{l}\text { Mesteparten } \\
\text { av tiden }\end{array}$ & Hele tiden \\
\hline $\begin{array}{l}\text { 3. Har du vært plaget med rumling i magen i } \\
\text { løpet av de siste } 4 \text { ukene? }\end{array}$ & $\begin{array}{l}\text { Ikke i det } \\
\text { hele tatt }\end{array}$ & Litt av tiden & $\begin{array}{l}\text { En del av } \\
\text { tiden }\end{array}$ & $\begin{array}{l}\text { Mesteparten } \\
\text { av tiden }\end{array}$ & Hele tiden \\
\hline $\begin{array}{l}\text { 4. Har du vært oppblåst i magen i løpet av de } \\
\text { siste } 4 \text { ukene? }\end{array}$ & $\begin{array}{l}\text { Ikke i det } \\
\text { hele tatt }\end{array}$ & Litt av tiden & $\begin{array}{l}\text { En del av } \\
\text { tiden }\end{array}$ & $\begin{array}{l}\text { Mesteparten } \\
\text { av tiden }\end{array}$ & Hele tiden \\
\hline $\begin{array}{l}\text { 5. Har du vært plaget med diaré i løpet av de } \\
\text { siste } 4 \text { ukene? }\end{array}$ & $\begin{array}{l}\text { Ikke i det } \\
\text { hele tatt }\end{array}$ & Litt av tiden & $\begin{array}{l}\text { En del av } \\
\text { tiden }\end{array}$ & $\begin{array}{l}\text { Mesteparten } \\
\text { av tiden }\end{array}$ & Hele tiden \\
\hline $\begin{array}{l}\text { 6. Har du hatt følelsen av ufullstendig } \\
\text { tømming når du har vært på toilettet i løpet } \\
\text { av de siste } 4 \text { ukene? }\end{array}$ & $\begin{array}{l}\text { Ikke i det } \\
\text { hele tatt }\end{array}$ & Litt av tiden & $\begin{array}{l}\text { En del av } \\
\text { tiden }\end{array}$ & $\begin{array}{l}\text { Mesteparten } \\
\text { av tiden }\end{array}$ & Hele tiden \\
\hline $\begin{array}{l}\text { 7. Har du vært plaget med sultsmerter i løpet } \\
\text { av de siste } 4 \text { ukene? }\end{array}$ & $\begin{array}{l}\text { Ikke i det } \\
\text { hele tatt }\end{array}$ & Litt av tiden & $\begin{array}{l}\text { En del av } \\
\text { tiden }\end{array}$ & $\begin{array}{l}\text { Mesteparten } \\
\text { av tiden }\end{array}$ & Hele tiden \\
\hline $\begin{array}{l}\text { 8. Har du vært plaget av manglende } \\
\text { overskudd i løpet av de siste } 4 \text { ukene? }\end{array}$ & $\begin{array}{l}\text { Ikke i det } \\
\text { hele tatt }\end{array}$ & Litt av tiden & $\begin{array}{l}\text { En del av } \\
\text { tiden }\end{array}$ & $\begin{array}{l}\text { Mesteparten } \\
\text { av tiden }\end{array}$ & Hele tiden \\
\hline $\begin{array}{l}\text { 9. Har du vært plaget av hodepine i løpet av } \\
\text { de siste } 4 \text { ukene? }\end{array}$ & $\begin{array}{l}\text { Ikke i det } \\
\text { hele tatt }\end{array}$ & Litt av tiden & $\begin{array}{l}\text { En del av } \\
\text { tiden }\end{array}$ & $\begin{array}{l}\text { Mesteparten } \\
\text { av tiden }\end{array}$ & Hele tiden \\
\hline $\begin{array}{l}\text { 10. Har du fyset på spesiell mat i løpet av de } \\
\text { siste } 4 \text { ukene? }\end{array}$ & $\begin{array}{l}\text { Ikke i det } \\
\text { hele tatt }\end{array}$ & Litt av tiden & $\begin{array}{l}\text { En del av } \\
\text { tiden }\end{array}$ & $\begin{array}{l}\text { Mesteparten } \\
\text { av tiden }\end{array}$ & Hele tiden \\
\hline $\begin{array}{l}\text { 11. Har du hatt manglende matlyst i løpet av } \\
\text { de siste } 4 \text { ukene? }\end{array}$ & $\begin{array}{l}\text { Ikke i det } \\
\text { hele tatt }\end{array}$ & Litt av tiden & $\begin{array}{l}\text { En del av } \\
\text { tiden }\end{array}$ & $\begin{array}{l}\text { Mesteparten } \\
\text { av tiden }\end{array}$ & Hele tiden \\
\hline $\begin{array}{l}\text { 12. Relatert til din cøliaki, hvordan er helsen } \\
\text { din? }\end{array}$ & Utmerket & God & Ganske god & Dårlig & $\begin{array}{l}\text { Meget } \\
\text { dårlig }\end{array}$ \\
\hline 13. Generelt sett, hvordan er helsen din? & Utmerket & God & Ganske god & Dårlig & $\begin{array}{l}\text { Meget } \\
\text { dårlig }\end{array}$ \\
\hline $\begin{array}{l}\text { 14. Hvor mye fysisk smerte har du hatt i } \\
\text { løpet av de siste } 4 \text { ukene? }\end{array}$ & Ingenting & Litt & En del & $\begin{array}{l}\text { Ganske } \\
\text { mye }\end{array}$ & Veldig mye \\
\hline 15. Jeg har det (helsemessig) bra & Sterkt enig & Noe enig & $\begin{array}{l}\text { Verken enig } \\
\text { eller uenig }\end{array}$ & Noe uenig & Sterkt uenig \\
\hline $\begin{array}{l}\text { 16. Jeg er like frisk som hvem som helst } \\
\text { andre jeg kjenner }\end{array}$ & Sterkt enig & Noe enig & $\begin{array}{l}\text { Verken enig } \\
\text { eller uenig }\end{array}$ & Noe uenig & Sterkt uenig \\
\hline
\end{tabular}




\section{Giessener Beschwerdebogen (GBB)}

Se tilbake på hvordan du har hatt det den siste uken og sett ett kryss for hvert av de seks spørsmålene.

Dato:

Jeg føler meg belastet med følgende plager.

1. Slapphet/svakhet

$\square$ Ikke

$\square$ Muligens litt

$\square$ Noe

$\square$ Betydelig $\square$ Sterkt

2. Overdrevent søvnbehov

$\square$ Ikke

$\square$ Muligens litt

$\square$ Noe

Betydelig $\square$ Sterkt

3. Fort sliten/utmattet

$\square$ Ikke

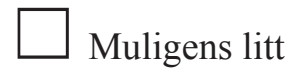

$\square$ Noe

$\square$ Betydelig $\square$ Sterkt

4. Tretthet

$\square$ Ikke
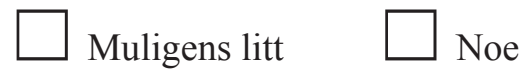

Betydelig $\square$ Sterkt

5. Følelse av å være "utenfor" eller fortumlet

$\square$ Ikke

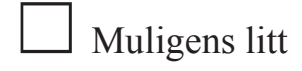

$\square$ Noe

$\square$ Betydelig $\square$ Sterkt

6. Følelse av utmattelse

$\square$ Ikke

$\square$ Muligens litt

$\square$ Noe

$\square$ Betydelig $\square$ Sterkt 


\section{Symptomregistrering (VAS-GBB)}

Se tilbake på den siste uken og sett én loddrett strek på linjen for å beskrive hvordan du har hatt det.

For eksempel:

Lite slapp

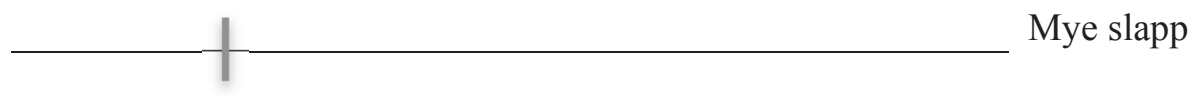

Dato:

Lite slapp/svak

Mye slapp/svak

Lite plaget av

overdrevent

Mye plaget av

søvnbehov

overdreven

søvnbehov

Lite plaget av fort

Mye plaget av fort

sliten/utmattet

sliten/utmattet

Lite trett

Mye trett

Lite "utenfor" eller

Mye "utenfor" eller

fortumlet

fortumlet

Lite utmattet

Mye utmattet

Lite følelse av

Mye følelse av

nummenhet $\mathrm{i}$ hender

og føtter

nummenhet $\mathrm{i}$ hender

og føtter

Lite følelse av

prikking $i$ hender og

føtter

Mye følelse av

prikking i hender og føtter

Lite opplevelse av manglende fokus

(konsentrasjon)

Mye opplevelse av manglende fokus

(konsentrasjon)

Lite ledd og

muskelsmerter

Mye ledd og

muskelsmerter

Lite deprimert

Veldig deprimert 


\section{Rikshospitalet - Radiumhospitalet HF}

Dato:

Versjon: Baseline

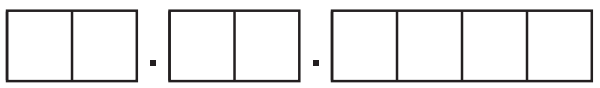

Deltaker ID

HAD

Dette spørreskjemaet er laget for å hjelpe oss til å forstå hvordan du føler deg. Les hver linje og marker i boksen for det svar som beskriver dine følelser DEN SISTE UKEN.

\section{Jeg er nervøs eller anspent}

$\square$ For det meste

$\square$ Ofte

Noen ganger

Ikke i det hele tatt

2. Jeg gleder meg fremdeles over ting jeg pleide å glede meg over

Avgjort like mye

$\square$ Ikke fullt så mye

Bare litte grann

Ikke i det hele tatt
4. Jeg kan le og se det morsomme $i$ situasjoner

$\square$ Like mye som jeg alltid har gjort

Ikke like mye nå som før

Avgjort ikke så mye nå som før

Ikke i det hele tatt

5. Jeg har hodet fullt av bekymringer
Veldig ofte
Ganske ofte
Av og til
En gang i blant

\section{Jeg er i godt humør}

\section{Jeg har en urofølelse som om} noe forferdelig kommer til å skje

$\square$ Helt sikkert og svært ille

$\square$ Aldri

$\square$ Ja, men ikke så veldig ille

$\square$ Noen ganger

Litt ille, men det bekymrer meg ikke så mye

Ganske ofte

Ikke i det hele tatt 


\section{Jeg kan sitte i fred og ro og} kjenne meg avslappet

Ja, helt klart

Vanligvis

Ikke så ofte

Ikke i det hele tatt
11. Jeg føler meg rastløs som om jeg stadig må være i aktivitet

Uten tvil svært mye

Ganske mye

Ikke så veldig mye

Ikke i det hele tatt
8. Jeg føler det som om alt går langsommere

$\square$ Nesten hele tiden

Svært ofte

Fra tid til annen

Ikke i det hele tatt

9. Jeg føler meg urolig liksom jeg har sommerfugler i magen

$\square$ Ikke i det hele tatt

$\square$ Fra tid til annen

Ganske ofte

Svært ofte

10. Jeg har sluttet å bry meg om hvordan jeg ser ut

$\square$ Ja, helt klart

$\square$ Jeg bryr meg ikke så mye som jeg burde

Det kan nok hende at jeg ikke bryr meg nok

Jeg bryr meg om utseendet like mye som jeg alltid har gjort
12. Jeg ser med glede frem til hendelser og ting

$\square$ Like mye som jeg alltid har gjort

$\square$ Heller mindre enn jeg pleier

Avgjort mindre enn jeg pleier

Nesten ikke i det hele tatt

13. Jeg kan plutselig få en følelse av panikk

14. Jeg kan glede meg over en god bok eller et radio eller TV-program

$\square$ Svært ofte

Ikke så veldig ofte

Ikke i det hele tatt 


\title{
Rikshospitalet - Radiumhospitalet HF
}

Glutenstudiene 2014

Versjon: Baseline

Dato:

\author{
Versjon: Baseline
}

SF-36

Dette spørreskjemaet spør om hvordan du ser på din egen helse. Disse opplysningene vil hjelpe oss til å få vite hvordan du har det og hvordan du er i stand til å utføre dine daglige gjøremål. Hvert spørsmål skal besvares ved å sette et kryss i boksen for det alternativet som passer best for deg. Hvis du er usikker på hva du skal svare, vennligst svar så godt du kan på alle spørsmålene.

1. Stort sett vil du si at din helse er:

Utmerket

Meget god

$\square$ God

$\square$ Nokså god

Dårlig
2. Sammenlignet med for et år siden, hvordan vil du si at din helse stort sett er nå?

$\square$ Mye bedre nå enn for et år siden siden

$\square$ Litt bedre nå enn for et år siden

$\square$ Omtrent det samme som for et år siden

$\square$ Litt dårligere nå enn for et år siden

Mye dårligere nå enn for et år siden

3. De neste spørsmålene handler om aktiviteter som du kanskje utfører i løpet av en vanlig dag. Er din helse slik at den begrenser deg i utførelsen av disse aktivitetene nå? Hvis ja, hvor mye?

A. Anstrengende aktiviteter som å løpe, løfte tunge gjenstander, delta i anstrengende idrett....
$\square$ Ja, begrenser meg mye.
Ja, begrenser meg litt.
Nei, begrenser meg ikke i det hele tatt.

B. Moderate aktiviteter som å flytte et bord, støvsuge, gå en tur eller drive med hagearbeid
Ja, begrenser meg mye.
Ja, begrenser meg litt.
Nei, begrenser meg ikke i det hele tatt.

C. Løfte eller bære en handlekurv
$\square \mathrm{Ja}$, begrenser meg mye.
Ja, begrenser meg litt.
Nei, begrenser meg ikke i det hele tatt.

D. Gå opp trappen flere etasjer

$\square$ Ja, begrenser meg mye.

Ja, begrenser meg litt.

E. Gå opp trappen en etasje

Ja, begrenser meg mye.

$\square$ Ja, begrenser meg litt.

Nei, begrenser meg ikke i det hele tatt.

F. Bøye deg eller sitte på huk 
G. Gå mer enn to kilometer

$\square$ Ja, begrenser meg mye.

H. Gå noen hundre meter

$\square \mathrm{Ja}$, begrenser meg mye.

$\mathrm{Ja}$, begrenser meg litt.

Nei, begrenser meg ikke i det hele tatt.

I. Gå hundre meter

Ja, begrenser meg mye.

$\square$ Ja, begrenser meg litt.

Nei, begrenser meg ikke i det hele tatt.

J . Vaske deg eller kle på deg

Ja, begrenser meg mye.

$\square$ Ja, begrenser meg litt.
Nei, begrenser meg ikke i det hele tatt.
Nei, begrenser meg ike idethele tatt.

$\square$ Nei, begrenser meg ikke i det hele tatt.

4. I løpet av den siste uken, har du hatt noen av følgende problemer i ditt arbeid eller i andre av dine daglige gjøremål på grunn av din fysiske helse?
A. Har du redusert tiden du har brukt på arbeidet ditt eller andre aktiviteter? $\square \mathrm{Ja} \quad \square \mathrm{Nei}$
B. Har du utrettet mindre enn du hadde ønsket?

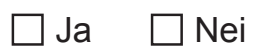
C. Har du vært hindret i visse typer arbeid eller andre
$\square \mathrm{Ja} \quad \square \mathrm{Nei}$ aktiviteter?
D. Har du hatt vanskeligheter med å utføre arbeidet ditt eller andre aktiviteter (f.eks. fordi det krevde ekstra anstrengelser)?

5. I løpet av den siste uken, har du hatt følelsesmessige problemer som har ført til vanskeligheter i ditt arbeid eller i andre av dine daglige gjøremål (f. eks. fordi du har følt deg deprimert eller engstelig)?
A. Har du redusert tiden du har brukt på arbeidet ditt eller andre aktiviteter
B. Har du utrettet mindre enn du hadde ønsket
$\square \mathrm{Ja} \quad \square$ Nei
C. Har du ikke arbeidet eller utført andre aktiviteter like nøye som vanlig
$\square$ Ja $\square$ Nei

6. I løpet av den siste uken, i hvilken grad har din fysiske helse eller følelsesmessige problemer hatt innvirkning på din vanlige sosiale omgang med familie, venner, naboer eller foreninger?
$\square$ Ikke i det hele tatt
$\square$ Litt
$\square$ Endel
$\square$ Mye
Svært mye 
7. Hvor sterke kroppslige smerter har du hatt i løpet av den siste ukene?

$\begin{array}{ll}\square \text { Ingen } & \square \text { Moderate } \\ \square \text { Meget svake } & \square \text { Sterke } \\ \square \text { Svake } & \square \text { Meget sterke }\end{array}$

8. I løpet av den siste uken, hvor mye har smerter påvirket ditt vanlige arbeid (gjelder både arbeid utenfor hjemmet og husarbeid)?

Hele tiden

Mye av tiden

Endel av tiden

9. De neste spørsmålene handler om hvordan du har følt deg og hvordan du har hatt det den siste uken. For hvert spørsmål, vennligst velg det svaralternativet som best beskriver hvordan du har hatt det. Hvor ofte i løpet av den siste uken har du:

A. Følt deg full av tiltakslyst?

$\square$ Hele tiden

$\square$ Endel av tiden

Nesten hele tiden

Mye av tiden
Litt av tiden

$\square$ Ikke i det hele tatt
B. Følt deg veldig nervøs?
Hele tiden
$\square$ Endel av tiden
Nesten hele tiden
Litt av tiden
Mye av tiden

C. Vært så langt nede at ingenting har kunnet muntre deg opp?

D. Følt deg rolig og harmonisk?

\begin{tabular}{|c|c|c|c|}
\hline$\square$ Hele tiden & $\square$ Endel av tiden & $\square$ Hele tiden & $\square$ Endel av tiden \\
\hline$\square$ Nesten hele tiden & $\square$ Litt av tiden & $\square$ Nesten hele tiden & $\square$ Litt av tiden \\
\hline$\square$ Mye av tiden & $\square$ Ikke i det hele tatt & $\square$ Mye av tiden & $\square$ Ikke i det hele tatt \\
\hline
\end{tabular}

E. Hatt mye overskudd?

F. Følt deg nedenfor og trist?

Hele tiden

$\square$ Endel av tiden

Hele tiden

Endel av tiden

Nesten hele tiden

Litt av tiden

Mye av tiden

Ikke i det hele tatt $\square$ Nesten hele tiden $\square$ Litt av tiden

Mye av tiden
Ikke i det hele tatt
G. Følt deg sliten?

$\square$ Hele tiden

$\square$ Nesten hele tiden

$\square$ Mye av tiden $\square$ Endel av tiden

Litt av tiden

$\square$ Ikke i det hele tatt
H. Følt deg glad?

$\square$ Hele tiden

$\square$ Endel av tiden

$\square$ Nesten hele tiden

$\square$ Mye av tiden
Litt av tiden

$\square$ Ikke i det hele tatt

I. Følt deg trett?

Hele tiden

Nesten hele tiden

Mye av tiden
Endel av tiden

Litt av tiden

Ikke i det hele tatt 
J . løpet av den siste uken, hvor mye av tiden har din fysiske helse eller følelsesmessige problemer påvirket din sosiale omgang (som det å besøke venner, slektninger osv.)?

$\square$ Hele tiden

Nesten hele tiden

Mye av tiden $\square$ Endel av tiden

$\square$ Litt av tiden

$\square$ Ikke i det hele tatt

10. Hvor RIKTIG eller GALT er hver av de følgende påstander for deg?

\section{Helt riktig Delvis Vet ikke Delvis galt Helt galt}
A) Det virker som om jeg blir lettere syk enn andre
B) Jeg er like frisk som de fleste jeg kjenner
C) Jeg forventer at min helse vil bli dårligere
D) Min helse er utmerket 


\section{Symptomdagbok}

\section{Registrering av ulike plager}

Symptomregistreringen skal fylles ut ved å sette én loddrett strek på linjen etter det som passer best med hvordan du har det. Denne dagboken skal fylles ut HVER DAG. For eksempel:

Lite magesmerte

Mye magesmerte

Dato:

Lite magesmerte

Lite oppblåsthet

Mye magesmerte

Lite luftavgang

Lite kvalme
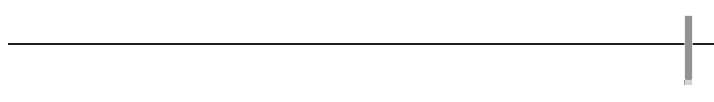

Fornøyd med avføringsmønster

Lite plager totalt

Mye oppblåsthet

Mye luftavgang

Mye kvalme

Ikke fornøyd med avføringsmønster

Mye plager totalt

Dato:

Lite magesmerte

Lite oppblåsthet

Lite luftavgang

Lite kvalme

Fornøyd med avføringsmønster

Lite plager totalt

Mye magesmerte

Mye oppblåsthet

Mye luftavgang

Mye kvalme

Ikke fornøyd med avføringsmønster

Mye plager totalt

Dato:

Lite magesmerte

Mye magesmerte

Lite oppblåsthet

Mye oppblåsthet

Lite luftavgang

Lite kvalme

Mye luftavgang

Fornøyd med avføringsmønster Mye kvalme

Ikke fornøyd med avføringsmønster

Lite plager totalt

Mye plager totalt 
Dato:

Lite magesmerte

Lite oppblåsthet

Lite luftavgang

Lite kvalme

Fornøyd med avføringsmønster

Lite plager totalt

Lite magesmerte

Lite oppblåsthet

Lite luftavgang

Lite kvalme

Fornøyd med avføringsmønster

Lite plager totalt

Lite magesmerte

Lite oppblåsthet

Lite luftavgang

Lite kvalme

Fornøyd med avføringsmønster

Lite plager totalt

Lite magesmerte

Lite oppblåsthet

Lite luftavgang

Lite kvalme

Fornøyd med avføringsmønster

Lite plager totalt
Mye magesmerte

Mye oppblåsthet

Mye luftavgang

Mye kvalme

Ikke fornøyd med avføringsmønster

Mye plager totalt

Dato:

Mye magesmerte

Mye oppblåsthet

Mye luftavgang

Mye kvalme

Ikke fornøyd med avføringsmønster

Mye plager totalt

Dato:

Mye magesmerte

Mye oppblåsthet

Mye luftavgang

Mye kvalme

Ikke fornøyd med avføringsmønster

Mye plager totalt

Dato:

Mye magesmerte

Mye oppblåsthet

Mye luftavgang

Mye kvalme

Ikke fornøyd med avføringsmønster

Mye plager totalt 
